University of Louisville

ThinkIR: The University of Louisville's Institutional Repository

Electronic Theses and Dissertations

$12-2012$

\title{
Zooplankton in freshwaters : potential responses to global warming, nutrient enrichment, and exotic jellyfish.
}

Allison S. Smith

University of Louisville

Follow this and additional works at: https://ir.library.louisville.edu/etd

\section{Recommended Citation}

Smith, Allison S., "Zooplankton in freshwaters : potential responses to global warming, nutrient enrichment, and exotic jellyfish." (2012). Electronic Theses and Dissertations. Paper 1354.

https://doi.org/10.18297/etd/1354

This Doctoral Dissertation is brought to you for free and open access by ThinkIR: The University of Louisville's Institutional Repository. It has been accepted for inclusion in Electronic Theses and Dissertations by an authorized administrator of ThinkIR: The University of Louisville's Institutional Repository. This title appears here courtesy of the author, who has retained all other copyrights. For more information, please contact thinkir@louisville.edu. 


\title{
ZOOPLANKTON IN FRESHWATERS:
}

POTENTIAL RESPONSES TO GLOBAL WARMING, NUTRIENT ENRICHMENT, AND EXOTIC JELLYFISH

\author{
By \\ Allison S. Smith \\ B.S., University of Louisville, 2006 \\ A Dissertation \\ Submitted to the Faculty of the \\ College of Arts and Sciences of the University of Louisville \\ In Partial Fulfillment of the Requirements \\ for the Degree of
}

Doctor of Philosophy

Department of Biology

University of Louisville

Louisville, Kentucky

December 2012 
Copyright 2012 by Allison S. Smith

All rights reserved 
ZOOPLANKTON IN FRESHWATERS: POTENTIAL RESPONSES TO GLOBAL WARMING, NUTRIENT ENRICHMENT, AND EXOTIC JELLYFISH

By

\author{
Allison S. Smith \\ B.S., University of Louisville, 2006 \\ A Dissertation Approved on
}

November 19, 2012

By the following Dissertation Committee

Margaret M. Carreiro

Dissertation Director 


\section{DEDICATION}

Chapter 1: Thank you to Dr. James Alexander for assistance in experimental design and preparation of the manuscript. Thank you also to Dr. Gary Cobbs for assistance with statistical analysis. This chapter is dedicated to the memory of Dr. Jeff Jack. "I've

known rivers;/ Ancient dusky rivers,/ My soul has grown deep like the rivers." (From a poem by Langston Hughes.) 


\title{
ABSTRACT \\ Zooplankton in Freshwaters: Potential Responses to Global Warming, Nutrient Enrichment, and an Exotic Jellyfish
}

\author{
Allison S. Smith \\ November 19, 2012
}

Aquatic ecosystems face major transformations as humans increasingly alter their environment by introducing exotic species and changing the temperature regime and nutrient availability of freshwater systems. The impacts of such alterations of conditions, resources and species composition on zooplankton are important to consider because zooplankton link primary producers to higher trophic levels.

Among recent exotic invaders of freshwater systems in Europe and the Western Hemisphere is Craspedacusta sowerbii. This freshwater cnidarian can impact zooplankton abundance and community composition, thus altering ecosystem energy transfer to higher trophic levels. In experiments described in chapters 2 and 3 of this dissertation, $C$. sowerbii was found to have a significant and differential effect on zooplankton taxa such as Bosmina sp., Daphnia sp., and copepods. While medusae greatly reduced abundances of these genera, other potential prey items, such as Keratella sp., did not show a response to medusa presence, indicating that $C$. sowerbii medusae differentially alter zooplankton communities. However, while C. sowerbii did not affect all potential prey items, some species such as the large D. magna were killed at high rates but not consumed. This indicates that the effects of $C$. sowerbii medusa presence are not 
only the result of prey consumption, but also extend to their killing effect on species they cannot ingest.

The rate of global warming is predicted to accelerate in the coming decades and temperate freshwater ecosystems will face alterations in response to these changing thermal conditions. Simultaneously we can expect that nitrogen input to aquatic systems will increase through the deposition of fossil fuel combustion products, fertilizer runoff and sewage inputs. Such increased inputs are having and will have greatly affected primary production in freshwater ecosystems. As nitrogen levels increase so does the probability of both primary and secondary producers becoming phosphorus limited. These alterations can have dramatic effects on zooplankton such as Daphnia, a common and important genus of Cladocera in many lakes and rivers. Together warming temperature and increased nitrogen availability are expected to affect the growth and reproduction of aquatic organisms such as Daphnia, which are often the link between primary producers and higher trophic levels. The experiments contained in Chapter 4 reveal that juvenile growth rate and reproductive output of D. magna and D. pulex, two ubiquitous species of Daphnia, can indeed be directly affected by temperature and nitrogen and phosphorus availability. Temperature was found to have the predicted positive relationship with growth rate and timing of reproduction. Food quality effects were strongest for $D$. pulex at intermediate temperatures near their growth optimum (15 $25^{\circ} \mathrm{C}$ ), with high quality food resulting in a significantly higher growth rate at these temperatures. Food quality had no detectably significant effect at the highest and lowest temperatures tested $\left(10\right.$ and $\left.30^{\circ} \mathrm{C}\right)$. D. magna was found to have the highest growth rate at $30^{\circ} \mathrm{C}$, indicating that the optimum or maximum temperature for this species' had not 
been found in this study; however, food quality resulted in a higher growth rate only at $25^{\circ} \mathrm{C}$. Reproductive output for both species responded strongly to temperature, with higher temperatures resulting in earlier reproduction and fewer days between clutches. Food quality had significant effects on D. magna reproduction at $25^{\circ} \mathrm{C}$ while D. pulex showed strong effects of food quality at the intermediate temperatures $\left(15\right.$ and $\left.20^{\circ} \mathrm{C}\right)$, just as was observed with this species' growth rate. The effects of these changing environmental conditions on Daphnia can potentially have fitness effects on the organism (e.g., alteration of predation risk) and cascading effects on aquatic food webs.

Understanding how changes in temperature and nutrient availability as well as the introduction of exotic species will impact zooplankton communities in manipulated model systems, such as those used in these experiments, can help reveal how these changes may alter aquatic ecosystems. In order to continue to reap the benefits of healthy freshwater systems such as drinking water, food, flood mitigation, and biodiversity, it is imperative to protect the integrity of aquatic systems so critical to sustaining our planet and human communities. 


\section{TABLE OF CONTENTS}

1. Introduction 5

2. Potential effects of the freshwater jellyfish Craspedacusta sowerbii

on zooplankton species abundance

10

3. Effects of Craspedacusta sowerbii Medusa Density on Consumption of Zooplankton Prey and Community Composition

4. Effects of Temperature and Food Quality on Daphnia Growth and Reproduction

5. Conclusions

References

Appendix

Cirriculum Vitae 


\section{LIST OF TABLES}

TABLE

PAGE

1. Effects of a single Craspedacusta sowerbii medusa on three individual prey items.

2. Zooplankton counts from the 2008 experiment.

3. P-values from a mixed model ANOVA from 2008 experiment. 38

4. Shannon Diversity index for the 2008 experimental treatments. 38

5. Zooplankton counts from the 2012 experiment. 38

6. P-values from a mixed model ANOVA from the 2012 experiment. 39

7. P-values for starting densities of zooplankton prey groups in the 2012 experiment.

8. Mortality rates for D. magna.

9. Mortality rates for D. pulex. 


\section{LIST OF FIGURES}

FIGURE

PAGE

1. Percent of prey consumed, killed, and left alive.

2. Medusa effect after 24 hours on abundance of the most common zooplankton species.

3. Experimental positioning of tanks in for 2008 jellyfish density experiment. $\quad 40$

4. Mean starting densities of prey items on day 0 .

5. Mean whole tank density of prey items after 2 days.

6. Comparison of clearance rates in low density and high density treatments. 41

7. Comparison of ingestion rates in low density and high density treatments. 42

8. Comparison of feeding rates in low density and high density treatments. $\quad 42$

9. Prey groups by percentage. 43

10. Food web diagram. 43

11. Growth rate for D. magna. 66

12. Growth rate for $D$. pulex. 66

13. Days before production of the first clutch of offspring for D. magna. 67

14. Number of molts before the first clutch of offspring for D. magna. 67

15. Days before production of the first clutch of offspring for D.pulex. 68

16. Number of molts before the first clutch of offspring for D. pulex. 68

17. Days before production of the third clutch of offspring by D. magna. 69 
18. Days before production of the third clutch of offspring by $D$. pulex.

19. Days between clutches of offspring for D. magna.

20. Average number of offspring per clutch for D. magna.

21. Average number of days between clutches of offspring for D. pulex.

22. Average number of offspring per clutch for $D$. pulex. 


\section{CHAPTER 1 \\ INTRODUCTION}

Temperate freshwaters continue to face many major transformations as humans increasingly impact their temperature, chemistry and species composition from local to global scales. These three factors interact to elicit responses that can be difficult to understand, let alone predict. Yet as the pace of change accelerates, it becomes increasingly important to understand how our freshwater systems will be altered by these changing conditions since they provide drinking water, may act as net sinks for carbon (Schindler et al. 1997) and contaminants (Winter et al. 2001), and affect terrestrial as well as aquatic biodiversity (Thuiller 2007, Spencer 1991).

\section{$\underline{\text { Increasing Temperatures }}$}

Global change models for North American temperate zones predict a continued increase in average air (Meehl \& Tebaldi 2004, Solomon et al. 2007) and freshwater temperatures (Chen \& Folt 1996) as well as increases in short-term temperature extremes (Karl et al. 2009, Houghton et al. 1990). In addition, winters are expected to become milder as the average minimum temperature increases. Using metanalysis, Easterling et al. (1997) found that in the northern hemisphere the spring temperature maximum had increased $1.4^{\circ} \mathrm{C}$, while the minimum winter temperature had increased almost $3{ }^{\circ} \mathrm{C}$ (Easterling et al. 1997) since 1950. As minimum winter temperatures increase, lakes and rivers in the Northern hemisphere have experienced delayed freezing and earlier ice 
breakup as a result of these warming trends (Livingstone et al. 2010, Magnuson et al. 2000).

While annual precipitation averages will remain relatively unchanged in North America, the same amount of precipitation is expected to occur in fewer, more extreme events (Karl et al. 2009, Solomon et al. 2007), thereby increasing the potential for large floods interspersed by long drought periods. These extreme flood events can lead to greater importation of soil, nutrients, pollutants and aquatic species through watersheds and floodplains, while drought events can interact with warmer air temperatures to affect temperature-depth profiles of aquatic systems. For example, due to lower water levels and warmer temperatures, thermal stratification may occur earlier, thereby limiting nutrient availability to primary producers in the photic zone for a longer period, and potentially eliminating deeper cold water refuges where animals have historically escaped temperature extremes. In fact, many temperate zone lakes already experience temperatures $\geq 25^{\circ} \mathrm{C}$ and lack a cold-water refuge (Moore et al. 1996). In deeper waters, warming may enhance stratification, thereby reducing the nutrients available for primary production (van de Waal et al. 2010) and lowering dissolved oxygen levels during summer months (Wilhelm \& Adrian 2008).

Temperature effects on ecosystem processes (Laudon et al. 2012), community composition (Albouy 2012), population dynamics (Schalau et al. 2008), food web structure (Wagner \& Benndorf 2007), competition (Hall et al. 2008), habitat associations (Suggitt et al. 2012), phenological responses (Orcutt \& Porter 1983, Adrian et al. 2006), and cycling of macronutrients (Statham 2012) in aquatic systems have received much 
attention. But the interaction of temperature and nutrient availability on biotic responses in aquatic systems, to my knowledge, has not been experimentally studied as comprehensively.

\section{Nutrient availability}

Increases in nutrient inputs (i.e., organic matter, nitrogen, phosphorus) to aquatic systems can be attributed to anthropogenic activities such as fossil fuel combustion, soil erosion, fertilizer runoff, and sewage inputs (Whitehead \& Crossman 2011, Galloway et al. 1995). Human-produced additions of bioreactive nitrogen inputs to earth's ecosystems now exceed historic levels of naturally-produced nitrogen by at least a factor of ten, and have risen from $15 \mathrm{Tg} \mathrm{N} \mathrm{yr}^{-1}$ in 1860 to $187 \mathrm{Tg} \mathrm{N} \mathrm{yr}^{-1}$ in 2005 (Galloway et al. 2008, Vitousek et al. 1997).

While inputs of phosphorus have also increased primarily due to greater fertilizer application, industrial products such as pesticides, herbicides, and steel production, phosphorus is retained in soil more effectively than nitrogen (Kopáĉek et al. 1995). The higher rates of nitrogen entering aquatic systems through both runoff and atmospheric deposition may potentially lead to changes in N:P stoichiometry in freshwater bodies. Consequently, phosphorus limitation of primary production (Elser et al. 2007), shifts in phytoplankton community composition (Saros et al. 2005) and changes in C:N:P quality of food resources in aquatic food webs may occur as nitrogen levels rise above limiting levels (Elser et al. 2009, Elser et al. 2010, Whitehead \& Crossman 2012). 
Nutrient enrichment can also alter the way systems respond to other factors such as climate warming. Nutrient-poor systems may be more resistant to warming, since production is already limited by resource availability, whereas nutrient enriched systems may be less resistant to small increases in temperature with increases in productivity since limitation by nutrients is absent (O'Connor et al. 2009). Warming of water bodies can amplify the effect of nitrogen enrichment on herbivores by increasing primary production rates, but other factors such as the presence of sediment in the water column can suppress this affect (Thompson et al. 2008, O'Connor 2009). These non-additive effects make predicting impacts of both nutrient enrichment and warming on freshwater systems problematic and enhance the need for further experimental exploration of how warming and nutrient availability will interact to alter aquatic ecosystems.

\section{Exotics Species}

The introduction of exotic species by humans has already had substantial effects on ecosystems (Dukes and Mooney 2004, Pejchar and Mooney 2009, Strayer et al. 2006). In combination with increasing temperatures and nutrient availability, the ability of exotics to thrive in their introduced habitats has been greatly enhanced (Fey \& Cottingham 2011, Holzapfel \& Vinebrooke 2005). Warm-water species are growing increasingly common in higher latitudes as warmer temperatures allow them to establish and reproduce in regions previously too cold to sustain them (Holzapfel \& Vinebrooke 2005). Innumerable opportunities for introduction are available as humans more easily travel not only between regions but also continents (Jeschke and Strayer 2005). Whether transported by ballast water internationally or by recreational equipment between lakes, 
the result is the same: introduced species are quickly becoming the norm in many regions of the world with corresponding effects on native species and ecosystem processes in freshwater bodies (Ilarri et al. 2012, Ficetola et al. 2012, Vitousek et al. 1996, Lodge 1993).

This dissertation seeks to explore some aspects of the potential for temperature, nutrient availability, and exotic species to affect zooplankton communities and the life history traits of two common zooplankton species in freshwater ecosystems. In Chapters 2 and 3 , the effects of the exotic cnidarian, Craspedacusta sowerbii, on zooplankton communities is examined since these communities play a key role in linking primary producers to higher trophic levels of the food web (Chapters $2 \& 3$ ). In Chapter 4 , the effects of temperature and nutrient availability on the growth and reproduction of two common Daphnia species is investigated. Chapter 5 summarizes key findings of these experiments and suggests their potential implications for freshwater systems. It is hoped that this work enhances our understanding of the complex roles that temperature, nutrients, and exotic species will have on freshwater food webs in a world experiencing exponential global changes. 


\section{CHAPTER 2}

\section{POTENTIAL EFFECTS OF THE FRESHWATER JELLYFISH CRASPEDACUSTA SOWERBII ON ZOOPLANKTON SPECIES ABUNDANCE}

\section{Introduction}

Of the twenty known species of freshwater jellyfish (Phylum Cnidaria, Class Hydrozoa, Family Olindiidae) only Craspedacusta sowerbii (Lankester 1880) has been observed in North America (Jankowski 2001). Originating in the Yangtze River in China (Jankowski 2001), this species was first detected outside Asia at an aquaculture exhibit in Regent's Park, London, in the 1880s (Pennak 1989), due to inclusion of their polyps in imported water lilies (Slobodkin and Bossert 1991). Since then, Craspedacusta has been observed on every continent except Antarctica and has the widest distribution of all the freshwater jellyfish (Jankowski 2001, Dumont 1994).

Craspedacusta's life cycle includes three means of asexual reproduction. The polyps typically are minute (about $1 \mathrm{~mm}$ ) and form small colonies. Polyps can bud off new polyps to form a colony, or they can produce a frustule bud, which develops into a frustule larva and eventually a new polyp (Slobodkin and Bossert, 1991).

Craspedacusta also can reproduce asexually by producing medusal buds that generate several miniature medusae that in turn grow into sexually reproductive adults, approximately $20 \mathrm{~mm}$ in diameter (Boothroyd et al. 2002). The medusae release gametes into the water column where fertilization occurs, and zygotes subsequently develop into 
planula larvae. The planula larvae settle to the benthos and complete the life cycle by producing new polyps.

Sexual reproduction is rare. It is believed that the only mixed-sex medusa blooms occur in the Yangtze River, where they originated, and most of the other populations around the globe are of a single sex (Pennak, 1989; but see Acker 1976). These medusa blooms can be sizable and dense, with Jankowski (2000) and Jankowski et al. (2005) reporting a range of 400 to 1000 ind $\mathrm{m}^{-2}$ in a pond in Germany.

Both polyps and medusae feed on zooplankton. The short, cnidocyte-laden tentacles are present in whorls around the outer edge of the bell-shaped body, and are used to sting and paralyze prey. Research into the feeding of adult medusae has shown that Craspedacusta medusa blooms can negatively impact abundances of adult copepods, copepod nauplii and the cladoceran, Bosmina longirostris Müller 1785 (Jankowski and Ratte, 2000; Jankowski et al. 2005; Smith and Alexander 2008). In large enclosure experiments, jellyfish medusae presence has been shown to induce defensive responses in B. longirostris, such as longer antennule length, more eggs per brood, and larger overall adult size (Jankowski 2004). However, results of studies performed in contained spaces should be considered in context, as Martin (2001) found that mesocosm experiments with comb jellies had compromised field relevance due to the effects of enclosure size on predator-prey interactions.

With respect to Craspedacusta's potential predators, only adult crayfish appear to consume adult medusae and polyps. Fish and predatory insects have not been 
observed to consume C. sowerbii of any life stage (Davis, 1955; Dodson and Cooper, 1983).

The purpose of the current studies was to examine the effects of medusa presence on natural zooplankton community composition and abundance. To do this, I first performed two feeding experiments to determine the ability of medusae to kill and consume three commonly dominant cladoceran species representing three prey size classes. Finally, I quantified the effect of medusa presence on a natural community of zooplankton obtained from the lake where the medusae were observed.

\section{Methods}

Medusae were collected from a pond in Thurman-Hutchins Park (21.5 ha), near downtown Louisville, KY, USA ( $38^{\circ} 16^{\prime} 55^{\prime}$ 'N, $\left.85^{\circ} 41^{\prime} 28^{\prime \prime} \mathrm{W}\right)$, located near the Ohio River. In late September of 2006, specimens were collected using a plankton tow net. The pond is annually stocked for recreational fishing with species including black crappie, red-ear sunfish, bluegills, and largemouth bass (Metro Parks Department, Louisville, $\mathrm{KY}$, personal communication). Medusae were placed in $0.7 \mu \mathrm{m}$-filtered Ohio River water in a large aquarium, and they were randomly selected for the three experiments, which were conducted at room temperature $\left(20-22^{\circ} \mathrm{C}\right)$. For the first two experiments, the three potential prey Daphnia magna Müller 1785, Daphnia lumholtzi Sars 1885, and Bosmina longirostris Müller 1785 were obtained from stock cultures originally collected in the Ohio River and maintained at the University of Louisville for at least 3 years. 
In the first experiment, a single medusa was placed in a $300 \mathrm{~mL}$ flask containing $250 \mathrm{~mL}$ of $0.7 \mu \mathrm{m}$-filtered Ohio River water with one of three potential prey species: three individuals of $D$. magna, five of $D$. lumholtzi, or ten of $B$. longirostris. This made prey biomass roughly equivalent. Control flasks contained prey but no medusa. After 24 hours, a count was made of the prey left alive and the prey dead but unconsumed and visible in the bottom of the flask. Dead/consumed animals were replaced daily for four days. Three replicate flasks were used for each prey type and controls.

In the second experiment, a single medusa was placed in a $300 \mathrm{~mL}$ flask containing $250 \mathrm{~mL}$ of $1 \mu \mathrm{m}$-filtered Ohio River water with all three prey items combined: three $D$. magna, five $D$. lumholtzi, and ten $B$. longirostris. This treatment was replicated five times. After 24 hours, a count was made of the prey left alive and the unconsumed dead prey in the flask.

In the third experiment, two medusae were placed in $800 \mathrm{~mL}$ of whole, unfiltered lake water in a $1 \mathrm{~L}$ flask. Controls contained whole, unfiltered lake water with no medusae. After 24 hours, the contents of each flask were filtered in a $23-\mu \mathrm{m}$ sieve and zooplankton were preserved in a $20 \%$ sugar -- $2 \%$ formalin solution (Haney and Hall 1972) for later identification. I focused on the responses of four taxa that were found in all samples: copepods, and nauplii larvae of copepod species, the rotifer, Ascomorpha sp., and the cladoceran, Bosmina longirostris. The experiment was run twice, two days apart, with fresh animals and water collected from the same lake two days after the first collection. For each experimental trial, eight replicates were used for both experimental and control treatments. 


\section{Statistical Analyses}

For the second experiment, a Fisher's Exact test (SAS 9.3.1) was used to determine homogeneity of the data and to detect any significant differences in the consumption of different prey items. For the third experiment, a two-sample Poisson test for means was used to determine if the abundance of prey items differed between the control and the medusa treatments. A Poisson test allows for the calculation of confidence intervals and hypothesis testing for the difference between means.

\section{Results}

In the first experiment, I found that while the controls showed little mortality (in some cases population increased due to reproduction), all three potential prey species suffered high mortality rates, approaching $100 \%$ each day, in the medusa treatments. While B. longirostris and D. lumholtzi were killed and consumed in high rates, the larger D. magna were also killed, but all of the corpses were still present at the bottom of the flask (Table 1).

Based on the results of the first experiment, I sought to determine in the second experiment if all three species of prey (simultaneously presented to the jellyfish) were equally likely to be consumed, once captured and killed. The data from all five replicates were found to be similar using Fisher's exact test and consequently were combined for analysis. While all three species of prey suffered high mortality rates, both $B$. longirostris and D. lumholtzi were significantly more likely to be consumed once killed, compared to D. magna (Fisher's exact test, $\chi^{2}=58.9, \mathrm{p}<0.00001$, Fig. 1). All $B$. 
longirostris and D. lumholtzi that were captured were consumed, whereas only $26.7 \%$ of the D. magna captured and killed subsequently were consumed (Fig. 1).

In the third experiment, we used a two-sample Poisson test for means to determine if the abundance of the species present in the whole lake water was significantly reduced by the presence of medusae. In the first experimental trial (Fig. 2), the abundances of the most commonly observed species in the experimental replicates were reduced by at least half compared to the controls: B longirostris $(\mathrm{p}<0.008)$, Ascomorpha sp. $(\mathrm{p}<0.002)$ and copepod nauplii $(\mathrm{p}=0.009)$. In the second trial, the abundances of Ascomorpha $(\mathrm{p}<0.048)$, adult copepods $(\mathrm{p}<0.029)$, and copepod nauplii $(p<0.0001)$ were again reduced by at least half in the presence of the medusa, compared to controls. The only species observed in the experimental treatment that was not significantly affected by medusa presence was $B$. longirostris in the second trial $(\mathrm{p}<$ 0.75); however, the $B$. longirostris densities in the control groups of the second run $($ mean $=2.3)$ were much lower than in the control treatments of the first run (mean $=$ 20.6, Fig. 2).

In the third experiment, other plankton were present, but most species were represented by a single individual. However, one other cladoceran, Diaphanosoma sp., may have been consumed by the medusae; a total of six individuals were present in control flasks, whereas none were found in the experimental flasks at the end of the experiment. 


\section{Discussion}

Previous work has shown that $C$. sowerbii medusae can significantly decrease the population sizes of zooplankton (Jankowski and Ratte 2000; Spadinger and Maier 1999). The results of this study confirm the results of these experiments. However, in our second experiment where all three taxa were introduced simultaneously, I had the opportunity to explore whether medusae selectively consumed prey based on size. In addition, in our third experiment I could observe the effects of medusa presence on a natural community of zooplankton. My experiments, both with a natural zooplankton community and selective prey offerings, found that prey consumption showed a size selection for the smaller organisms: rotifers and nauplii (about $0.1 \mathrm{~mm}$ in length), $B$. longirostris $(<0.5 \mathrm{~mm})$ and $D$. lumholtzi $(1-2 \mathrm{~mm})$, compared to the larger D. magna (3 to $5 \mathrm{~mm}$ ). This selectivity may be a function of the spacing between tentacle branches containing nematocysts as shown by Spadinger \& Maier (1999), who found that prey larger than $1.4 \mathrm{~mm}$ may be too large for Craspedacusta medusae to handle based on an analysis of medusa stomach contents. Dodson and Cooper (1983) found a similar pattern: Craspedacusta could kill and consume a variety of zooplankton between 0.2 and $2 \mathrm{~mm}$ in size. Larger zooplankton (from $2 \mathrm{~mm}$ to $8.8 \mathrm{~mm}$ long) were killed but not consumed. In our study, a similar size selectivity was detected in consumed prey although, despite the inability to consume $D$. magna, medusae killed individuals of this species at a higher rate than even $D$. lumholtzi. With respect to capturing and killing potential prey, no selectivity was evident; the jellyfish killed all zooplankton that they encountered, at least within the size ranges used in this study. 
My results demonstrate the potential effect of medusae on zooplankton communities. When placed in whole lake water with a natural complement of zooplankton, medusae significantly reduced the number of all prey species present, except for B. longirostris in one trial. However, as can be noted in Fig. 2, the population of $B$. longirostris was an order of magnitude lower in the second run of this experiment, making detection of an effect difficult. I believe this decrease in population before our trial may be the result of longer exposure to the medusa bloom since whole lake water was obtained for the second trial two days after water for the first trial. The lack of a significant effect of medusae on $B$. longirostris in this trial may be the result of decreased encounter rate, because the population had been so diminished.

While blooms of C. sowerbii may be infrequent and sporadic, they have the potential to significantly alter aquatic food webs by removing a sizable proportion of the plankton (Davis 1955; Boothroyd et al. 2002). Blooms typically occur in late summer/early fall and may coincide with the autumn phytoplankton bloom in temperate lakes (Winder and Cloern 2010). Spadinger \& Maier (1999) estimated that each medusa consumed about 190 zooplankton per day, at a mean prey density of about 100 zooplankton per liter. Dodson and Cooper (1983) estimated that each medusa could clear up to $0.9 \mathrm{~L}$ water/day for consumed prey, and clear up to $64 \mathrm{~L} /$ day for larger nekton, which were killed but not eaten. The zooplankton on which medusae feed are often the crucial link between primary producers and higher trophic levels (Williamson and Stoeckel, 1989; Brooks and Dodson, 1965; Carpenter and Kitchell, 1984), and thus the polyps and medusae may have cascading effects on primary producers. In addition, changes in zooplankton community abundance can significantly alter algal abundances as 
well as higher trophic levels, including planktivorous fish. Dodson and Cooper (1983) found that their Craspedacusta population killed both large predatory zooplankton (Leptodora sp.) and smaller predatory rotifers (Asplanchna sp.) that in turn feed upon very small rotifers, such as Keratella cochlearis and Brachionus angularis. The small rotifers $K$. cochlearis and B. angularis actually increased in predation experiments, presumably due to the strong decline in Asplanchna (Dodson and Cooper 1983). A strong shift in the composition of zooplanktivores may allow a substantial change in the herbivorous zooplankton, and potentially primary producers, causing a trophic cascade.

Medusae can kill small fish as well. My observations also include the initial incapacitation and eventual death of a small minnow that was contained in an aquarium with approximately six medusae. Craspedacusta sowerbii feeding may be passive, the result of encountering prey while drifting down through the water column (Dodson and Cooper, 1983; Pennak, 1989). The medusae occasionally lie on the bottom of the flasks, with their tentacles and manubrium facing up or they swim actively up to the surface and passively float downward through the water column, tentacles splayed outward and mouth downward (personal observation; Dodson and Cooper, 1983). Any zooplankton, macroinvertebrate or fish that medusae encounter will be stung with nematocysts. If the victim (as opposed to a prey item which is eaten) is small enough or the exposure to the medusa bloom long enough, death could result. Therefore, aquatic systems that experience a substantial bloom could be significantly altered through direct (predation) and indirect (incidental mortality), top-down tropic effects. Loss of algal grazers could result in higher algal biomass with cascading effects on dissolved oxygen and primary productivity. Changes in zooplankton abundance can have corresponding effects on 
planktivorous fish and higher trophic levels (Boothroyd et al., 2002; Jankowski et al., 2005).

Medusa blooms in marine environments have increased in frequency and abundance, possibly due to increasing temperatures, nutrient loading, and lower oxygen levels in our oceans (Mills 2001). While the cues for induction of medusa blooms in $C$. sowerbii are currently unknown, it has been suggested that blooms are closely associated with higher temperatures (Boothroyd et al., 2002, Slobodkin and Bossert, 1991). If current trends continue, I expect increased temperatures and higher levels of nutrient loading in our freshwater systems (increase in lake temperatures: Schindler 2001; increase in air temperatures: IPPC 2007; increase in stream temperatures: Paul and Meyer, 2001). If the present increase in freshwater temperatures continues, it is possible there may be an increase in C. sowerbii blooms, with cascading effects on aquatic food webs. 
Table 1. Effects of a single Craspedacusta sowerbii medusa on three individual prey items over four consecutive days at a density equivalent to 0.25 medusa $\mathrm{L}^{-1}$. Three replicates were averaged ( \pm S.E.) for each treatment and the control. Controls contained prey but no medusa.

\begin{tabular}{|l|l|l|l|l|}
\hline Prey treatment & Day 1 & Day 2 & Day 3 & Day 4 \\
\hline D. magna & & & & \\
\hline$\%$ consumed & 0 & 0 & 0 & 0 \\
\hline$\%$ killed, not eaten & $89 \pm 0.53$ & 100 & $78 \pm 0.53$ & $89 \pm 0.53$ \\
\hline$\%$ alive & $11 \pm 0.53$ & 0 & $22 \pm 0.53$ & $11 \pm 0.53$ \\
\hline Controls: \% alive & 100 & 100 & $144 \pm 2.93$ & $155 \pm 1.89$ \\
\hline & & & & \\
\hline D. lumholtzi & & & & \\
\hline$\%$ consumed & 100 & $93 \pm 0.53$ & 100 & $67 \pm 2.63$ \\
\hline$\%$ killed, not eaten & 0 & $7 \pm 0.53$ & 0 & $13 \pm 1.05$ \\
\hline$\%$ alive & 0 & 0 & 0 & 20 \\
\hline Controls: \% alive & $87 \pm 0.53$ & $80 \pm 1.58$ & $87 \pm 1.05$ & $87 \pm 1.05$ \\
\hline & & & & \\
\hline B. longirostris & & & & \\
\hline$\%$ consumed & $87 \pm 1.05$ & 100 & 100 & $97 \pm 0.53$ \\
\hline$\%$ killed, not eaten & $13 \pm 1.05$ & 0 & 0 & 0 \\
\hline$\%$ alive & 0 & 0 & 0 & 3 \\
\hline Controls: \% alive & 100 & 100 & 100 & $153 \pm 1.39$ \\
\hline
\end{tabular}




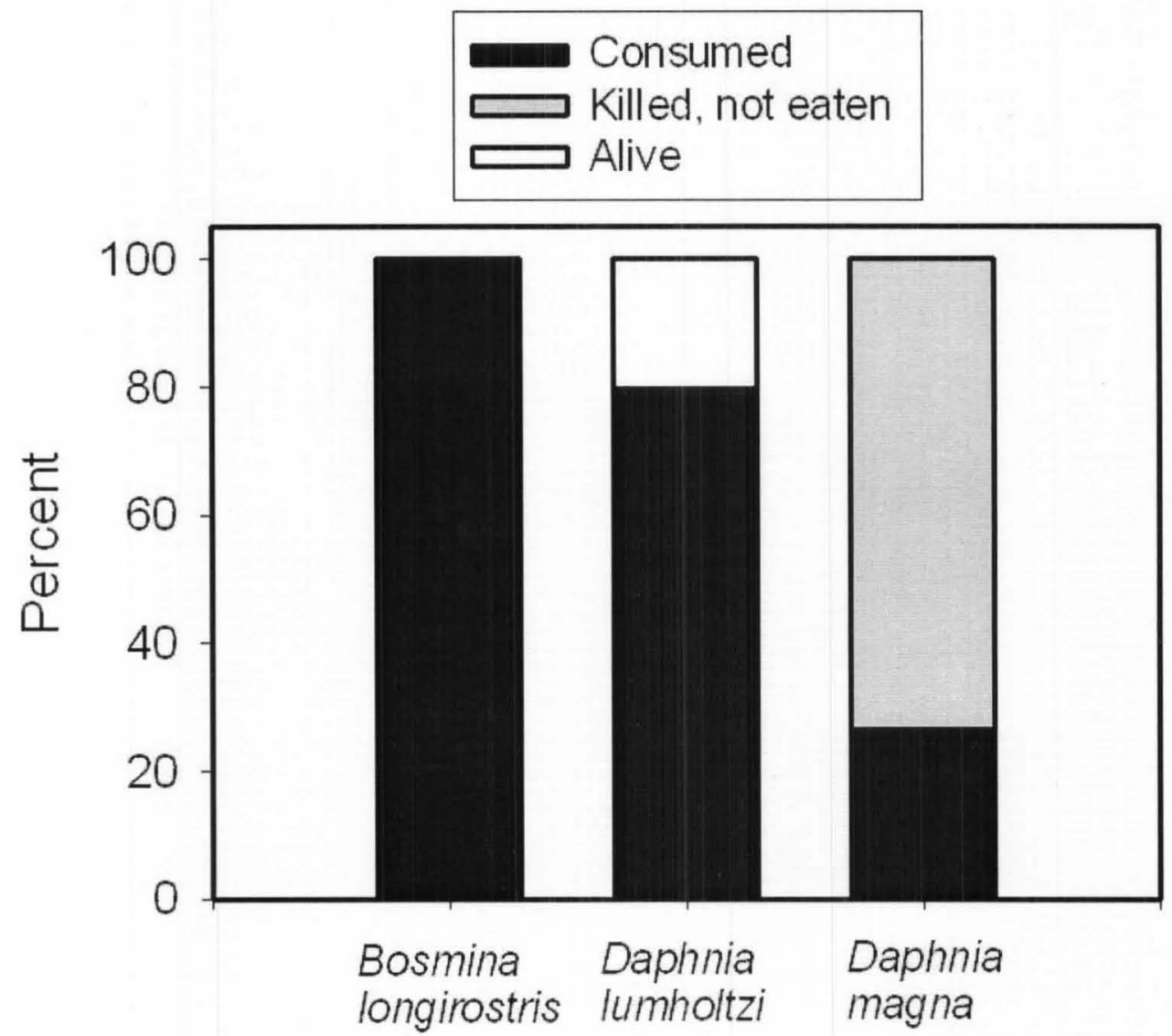

Fig. 1. Percent of each prey type consumed, killed (but not eaten), and left alive with three prey items together in the presence of one Craspedacusta sowerbii medusa. 


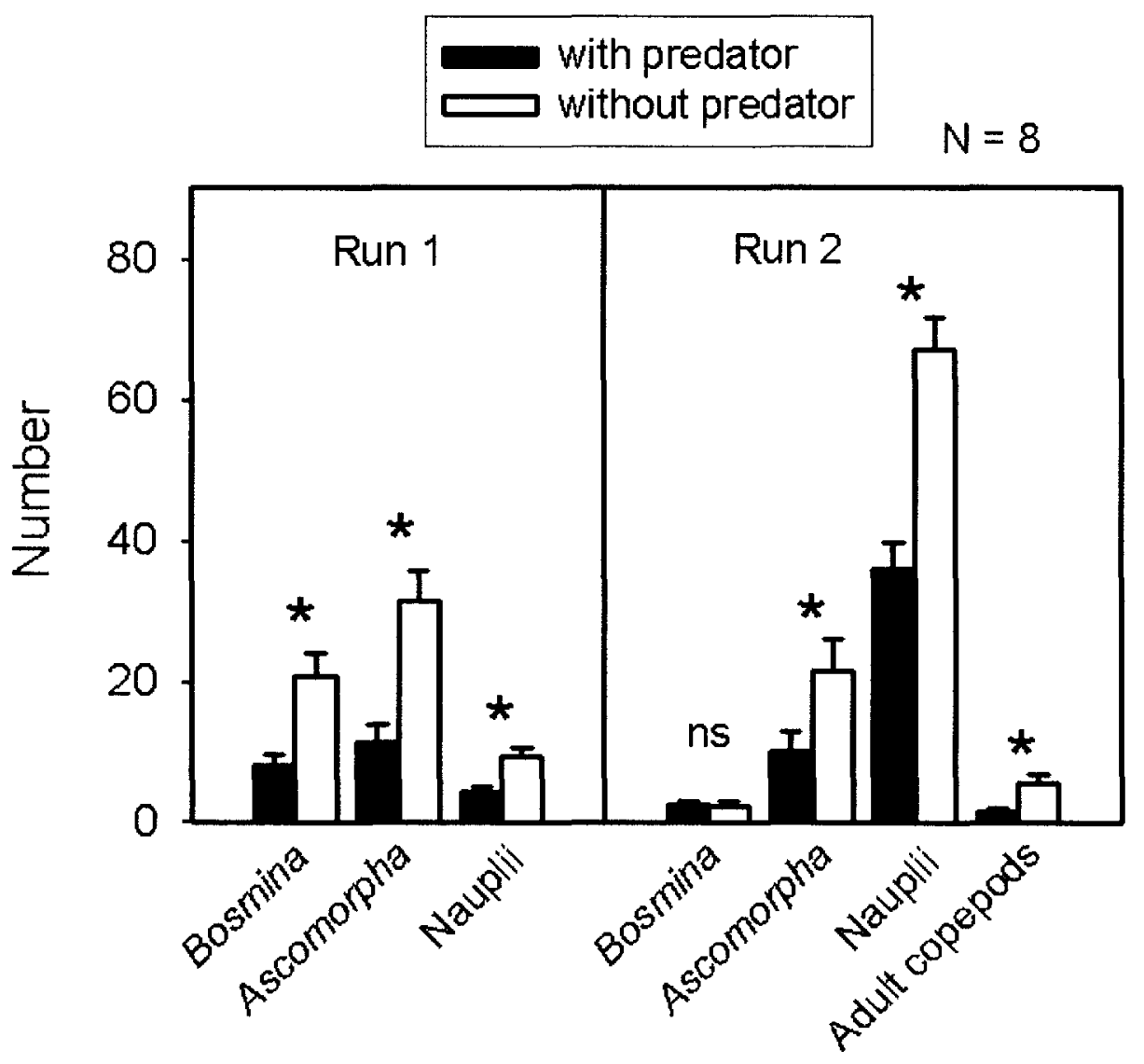

Fig. 2. Medusa effect after 24 hours on abundance ( \pm 1 S.E.) of the most common zooplankton species in $800 \mathrm{ml}$ of unfiltered lake water. Column pairs with an asterisk $\left(^{*}\right)$ were significant at $\mathrm{p} \leq 0.05$, Poisson test of means. $\mathrm{N}=8$ replicates per treatment. 


\section{CHAPTER 3}

\section{EFFECTS OF CRASPEDACUSTA SOWERBII MEDUSA DENSITY ON CONSUMPTION OF ZOOPLANKTON PREY AND COMMUNITY COMPOSITION}

\section{Introduction}

A wide range in the density of blooms of $C$. sowerbii medusae has been reported. These include values ranging from 1 individual (ind) $\mathrm{m}^{-3}$ in a gravel pit lake in Germany (Spadinger \& Maier 1999) to 2.52 ind $\mathrm{m}^{-2}$ in a reservoir in Spain (Pérez-Bote et al 2006),

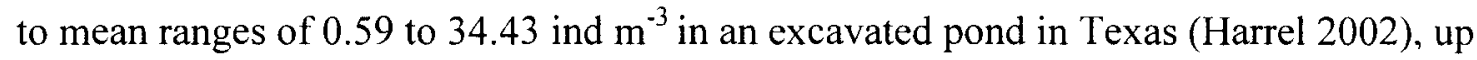
to highs ranging from 400 to 1000 ind $\mathrm{m}^{-2}$ in a pond in Germany (Jankowski 2000, Jankowksi et al. 2005). Such differences in the density of medusae should determine the magnitude of the effect of jellyfish medusa on zooplankton communities; however, no empirical studies have investigated the direct effects of varying medusa density on zooplankton density. While denser jellyfish blooms may result in higher predation, there may also be density dependent effects on the per individual predation rate among medusae, including increasing interference competition that could result in non-linear relationships between medusal density and prey capture. Medusae may also cause some prey taxa to increase indirectly as a result of preferential medusal removal of organisms that also consume those taxa as prey (Dodson \& Cooper 1983). 
C. sowerbii medusae are known to feed on zooplankton that range greatly in size. Common prey items include rotifers $(0.1-0.5 \mathrm{~mm})$, cladocerans $(0.2-6 \mathrm{~mm})$, and juvenile copepods (up to $1 \mathrm{~mm}$ ), as demonstrated in the previous chapter. Predation is known to alter size structure and composition of zooplankton communities, but often has little effect on the species richness of coexisting zooplankton species (Morin 1999), since predation seldom completely depletes the prey source. Nonetheless, predation effects on zooplankton community composition and size structure can then alter prey available for other zooplanktivores, such as insect larvae and young fish.

While blooms of $C$. sowerbii may be infrequent, sporadic, and short-lived, they have the potential to significantly alter aquatic food webs by removing a sizable proportion of the plankton (Davis 1955; Boothroyd et al. 2002, Smith and Alexander 2008). Spadinger \& Maier (1999) estimated that each medusa consumed about 190 zooplankton per day, at a mean prey density of about 100 zooplankton per liter. Dodson and Cooper (1983) estimated that each medusa could clear up to $0.9 \mathrm{~L} /$ day for consuming planktonic prey, and clear up to $64 \mathrm{~L} /$ day for larger nekton such as Letodora $(5.4 \mathrm{~mm})$ and Streptocephalus $(8.8 \mathrm{~mm})$, which were killed but not eaten.

Previous studies of the effect of $C$. sowerbii medusae on zooplankton have used gut content analysis correlated with zooplankton densities to estimate feeding rates (Spadinger \& Maier 1999, Boothroyd, Etheredge, and Green 2002, Stefani et al. 2010, Perez-Bote et al. 2006, Matsakis \& Conover 1991). Other studies from microcosm to lake scales have quantified the effects on zooplankton densities to reach such estimates. For example, Dodson and Cooper (1983) used $1 \mathrm{~L}$ flasks to conduct feeding experiments 
with medusae, but used a medusal density equivalent to 2376 medusae $\mathrm{m}^{-3}$, much higher than any densities reported in the literature. Jankowski (2001) used 1 L flasks with 5 medusae to estimate feeding rates, but these densities were also unrealistic. Subsequently, Jankowski (2004) set up a 23-day enclosure experiment in a natural lake to estimate the effects of more realistic medusal densities $\left(450\right.$ medusae $\left.\mathrm{m}^{-3}\right)$ on zooplankton and phytoplankton abundance.

The purpose of this study was to determine the potential effect of varying $C$. sowerbii medusal density on zooplankton abundance and community structure. The experiment was conducted in $75 \mathrm{~L}$ mesocosms with unfiltered pond water containing a natural complement of zooplankton. Unlike previous manipulative feeding studies of this species, I varied the density of medusae present in the experimental mesocosms by a factor of ten to determine if feeding interference occurred at higher densities of medusa. The range of densities used allowed for the calculation of feeding rates by medusae, and addressed potential density dependent effects on feeding rate, not by examining gut content, but by comparing densities of the most common zooplankton species after two days to their densities in control mesocosms containing no medusae.

\section{Methods}

\section{Medusae collection, mesocosm set-up and zooplankton measurements}

In October 2008, C. sowerbii medusae were collected using buckets from Stone Pond ( $\left.37^{\circ} 35^{\prime} 49.1496^{\prime \prime}, 84^{\circ} 49^{\prime} 5.664^{\prime \prime}\right)$ in Danville, Kentucky and transported in $20 \mathrm{~L}$ carboys containing whole pond water. Additional whole pond water was collected and 
transported back to the University of Louisville. Within 6 hours of pond water and medusae collection, nine indoor $75 \mathrm{~L}$ tanks were each filled with $20 \mathrm{~L}$ of well-mixed whole pond water, leaving each tank about $75 \%$ empty. Aeration was provided by small (38 L) fish tank pumps (one per tank) attached to stone aerators in each tank. Three tanks did not contain medusae and served as medusa-free controls, three tanks contained one medusa (low density treatment, equivalent to 50 medusae $\mathrm{m}^{-3}$ or 0.05 medusae $\mathrm{L}^{-1}$ ), and three tanks each contained 10 medusae (high density treatment, equivalent to 500 medusa $\mathrm{m}^{-3}$ or 0.5 medusae $\mathrm{L}^{-1}$ ) (Fig. 1). Therefore, all medusal densities were within the range reported in the literature. To sample the initial composition and density of the zooplankton community, a $500 \mathrm{ml}$ sample was collected from each tank immediately before adding medusae and filtered through a $50 \mu \mathrm{m}$ mesh filter. Zooplankton were preserved in a $20 \%$ sucrose $-2 \%$ formalin solution for later identification and quantification (Haney and Hall 1972). Additional $500 \mathrm{~mL}$ samples were collected from each tank two days after medusae were added. Counts of zooplankton present in each 500 $\mathrm{mL}$ sample were made using a plankton wheel and a stereo microscope at $25 \mathrm{x}$ magnification. Identifications were made based on Thorp and Kovich (1991) and Edmondson (1959).

In August of 2012, this experiment was repeated following the same procedures. Medusae and whole pond water from the same lake were collected in carboys and transported back to the University of Louisville. The same experiment was set up with the following changes: $75 \mathrm{~L}$ tanks contained $10 \mathrm{~L}$ of whole pond water (instead of $20 \mathrm{~L}$ ), leaving tanks about $85 \%$ empty, and the high density treatments contained 5 medusae instead of 10. All other methods were identical. 


\section{Zooplankton Abundance, Medusal Feeding Rate Determination and Statistics}

The starting densities in the tanks were sampled to determine if they were similarly mixed. Only five taxa were present in any of the tanks. The absolute number of prey items in each tank after 2 days was obtained by multiplying densities in the 500 $\mathrm{ml}$ subsample by two to convert to number prey $\operatorname{liter}^{-1}$.

Zooplankton abundance differences between the control and medusal treatment tanks were used to calculate clearance rates $(F)$, instantaneous ingestion rates $\left(I_{i}\right)$, and medusal feeding rates using the equation of Reid and Williamson (2009):

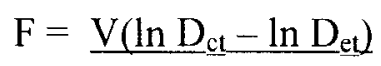

NT

where $\mathrm{V}$ is the volume of water in the tank, $\mathrm{D}_{\mathrm{ct}}$ and $\mathrm{D}_{\mathrm{et}}$ are the densities of zooplankton (individuals $\mathrm{L}^{-1}$ ) in the control and experimental mesocosm tanks at the end of the incubation, $\mathrm{N}$ is the number of medusae per tank and $\mathrm{T}$ is the duration of the experiment in days. Sampling was unable to distinguish between live and dead zooplankton due to mixing before sampling. Thus, feeding rates expressed are considered actual consumption rates and likely underestimate the effect of medusae on zooplankton densities.

Count data across all tanks before medusae were added were analyzed using ANOVA to determine if there were statistically significant differences in the starting densities of zooplankton in the tanks. Count data from days 2 were analyzed with a mixed model ANOVA (SAS 9.3.1) with treatment as a fixed effect and replicate mesocosm as a random factor. A post-hoc analysis was performed to determine which treatments were 
significantly different. Count data did not require transformation for these analyses. A post-hoc analysis was performed to determine which treatments were significantly different. A t-test (SAS 9.3) was used to determine significant differences in medusa feeding, clearance, and ingestion rates between low and high density treatments.

Shannon Diversity $\left(\mathrm{H}^{\prime}\right)$ was calculated for the three treatments (control, low density and high density) using the formula

$$
H^{\prime}=-\Sigma p_{i} \ln \left(p_{i}\right)
$$

where $p_{i}$ is the relative abundance of each group of organisms (Shannon 1948).

\section{Results}

\section{Initial conditions before medusal treatment}

Starting densities of prey items in the tanks were not found to statistically differ and were assumed to be similar and adequately mixed (Copepods $\mathrm{p}=0.75$, Keratella $s p$. $\mathrm{p}=0.78$, nauplii $\mathrm{p}=0.68$, and Polyarthra $\mathrm{s} p . \mathrm{p}=0.62 ;$ Fig. 4 ). The prey populations at high enough densities to be measurable were adult copepods, nauplii (juvenile copepods), Keratella sp., and Polyarthra sp. (Table 2). Copepods range in size from $<0.5$ to $5 \mathrm{~mm}$, while nauplii are $<0.5 \mathrm{~mm}$. Keratella and Polyarthra are both rotifers approximately $150 \mu \mathrm{m}$ in length.

\section{Effect of medusal density on Zooplankton abundance}

After 2 days, prey densities (Figure 5) were statistically higher in the control treatments compared to medusa treatments for copepods $(\mathrm{p}=0.007)$, nauplii $(\mathrm{p}=0.008)$, 
and Polyarthra $(\mathrm{p}=0.015)$, but not for Keratella $(\mathrm{p}=0.633)$. Post hoc analysis revealed that for copepods, the control densities were significantly higher than in both the high density $(p=0.003)$ and the low density treatment $(p=0.010)$, but the high and low density treatments did not differ from each other significantly $(\mathrm{p}=0.156)$. Nauplii densities were significantly lower in the high density treatment compared to the low density treatment $(p=0.016)$ as well as to the control $(p=0.004)$, but the control and low density treatments were not statistically different $(\mathrm{p}=0.098)$. Polyarthra showed the same pattern with the high density treatment having significantly lower densities than the control $(p=0.006)$ and the low density treatment $(\mathrm{p}=0.032)$. The control and the low density treatment did not differ significantly $(\mathrm{p}=0.104)$.

Post-hoc contrasts were conducted to determine which treatments were significantly different in the two groups that showed a significant difference in percent change. Nauplii in the control were higher than those in the high density treatment, while the low density treatment did not differ statistically from either. After 2 days (Fig. 7), Polyarthra sp. in the control tanks was also higher than in the high density medusal treatment, but their numbers in the low density treatment did not differ from either control or high density treatments.

A test of the treatment effects and their interaction (Table 3) found a significant interaction effect for both nauplii $(\mathrm{p}=0.019)$ and Polyarthra sp. $(\mathrm{p}=0.0016)$. 


\section{Clearance and Ingestion Rates}

Clearance rates for both high and low density treatments were highest for copepods and lowest for Keratella (Figure 6). Clearance rates for nauplii were 4.8 and 28.4 liters predator ${ }^{-1}$ day $^{-1}$ for the low and high density treatments, respectively. For the low and high density treatments respectively, clearance rates for copepods were 13.2 and 37.7 liters predator ${ }^{-1}$ day $^{-1}$, while rates for Keratella were 2.9 and 2.2 liters predator ${ }^{-1}$ day ${ }^{1}$. For Polyarthra, clearance rates were 5.7 and 24.8 liters predator ${ }^{-1}$ day $^{-1}$ in the low and high density treatments, respectively. While there were no significant differences detected in clearance rates for low and high density treatments, clearance rates in the high density treatment were higher for all prey groups except Keratella.

Instantaneous ingestion rates (Figure 7) were highest for nauplii (1023 prey predator ${ }^{-1}$ day $^{-1}$ ) in the high density treatments, but in the low density treatment the rate was highest for Polyarthra (367 prey predator ${ }^{-1}$ day $\left.^{-1}\right)$. Again, rates were lowest for Keratella in both low (219 prey predator ${ }^{-1}$ day $\left.^{-1}\right)$ and high density (129 prey predator ${ }^{-1}$ day $^{-1}$ ) treatments. Ingestion rates for copepods were 240 prey predator $^{-1}$ day $^{-1}$ in the low density treatment and was 362 prey predator $^{-1}$ day $^{-1}$ in the high density treatment. There were no significant differences between ingestion rates for low and high density treatments, but high density ingestion rates were higher for all groups except Keratella.

\section{Feeding Rates}

Feeding rates (Figure 8) were higher in the high density treatment for all prey except Keratella, although none of the differences were statistically significant. Feeding 
rates in the low and high density treatments, respectively, were for nauplii 306 and 1617 prey predator ${ }^{-1}$ day $^{-1}$, for copepods 241 and 367 prey predator $^{-1}$ day $^{-1}$, for Keratella 219 and 128 prey predator ${ }^{-1}$ day $^{-1}$, and for Polyarthra 364 and 808 prey predator $^{-1}$ day $^{-1}$. Diversity

Shannon Diversity was calculated for each of the three treatments of medusa density in order to determine how predation intensity affected the diversity of the zooplankton community (Table 4$)$. In the high density treatment (10 medusae), Shannon diversity was reduced from 3.61 to 1.71 , and from 3.66 to 3.32 in the low density treatment ( 1 medusa). The community in the control treatment actually increased slightly in diversity, from 3.85 to 3.96 .

\section{Experiment}

Results from the 2012 replication of this experiment did not exhibit any significant effects of medusal density on zooplankton density or on feeding rate by medusae (Table 6). These results may have arisen due to the fact that zooplankton densities were initially much lower than in 2008 (Tables $2 \& 5$ ). The same groups of prey were found (nauplii, copepods, Keratella sp., and Polyarthra sp.) as well as Branchionus sp., and their starting densities before medusae addition did not differ significantly between replicates (Table 7). The record-breaking hot summer of 2012 may have played a role in the low numbers of zooplankton or longer exposure to the medusa bloom before samples were collected may have depleted the prey.

\section{Discussion}

Medusa Density Effects on Zooplankton Community Structure 
These results demonstrate the potential effect that medusae have in reducing zooplankton abundance. Populations of some prey groups were more depressed than others, potentially indicating greater preference by the medusae for these groups, or alternatively, from indirect effects of medusal feeding and injury on different zooplankton populations. At densities observed in nature for both zooplankton and medusae, $C$. sowerbii in these experiments were found over a period of a few days to have an impact on populations of three of the four zooplankton taxa found in the pond water. Nauplii (juvenile copepods), adult copepods, and the rotifer Polyarthra sp. were negatively affected by the presence of jellyfish at both high and low densities of medusae. The rotifer Keratella $s p$. was not significantly affected by the presence of medusae at either predator density. In fact, Keratella sp. increased in all treatments, particularly in the high medusa density treatment. This may have been due to the severe reduction in numbers of adult copepods, which feed on Keratella sp., in the high density treatment (Fig. 9). Such an indirect effect was observed by Dodson and Cooper (1983) when the small predatory rotifer Asplanchna sp. was consumed by medusae, thereby releasing other small rotifers like Keratella from predation. In addition, species in the Keratella genus have distinctive spines that act as a defense against predators (Gilbert and Stemberger 1984). This defense mechanism may have prevented the medusae from impacting the Keratella sp. populations. In addition, Keratella have been observed to be strongly phototaxic (C. Williamson, personal communication). This tendency to group near a light source may have reduced the encounter rate with medusae resulting in a higher survivorship and allowing for reproduction. 
No previous study has so far been found that varied the density of medusae in a manipulative feeding experiment and, therefore, the potential existence of density dependent effects has not been addressed in the freshwater jellyfish literature. In this experiment, significantly depressed feeding rates per individual predator in the high density treatment compared to the low density treatment may indicate interference competition between medusae for prey. While medusae do not appear to be affected by the nematocysts of other medusae, crowding could potentially cause depressed feeding rates per individual due to the tangling of tentacles or the local depletion of prey. This should be investigated further, possibly by manipulating densities of zooplankton prey to forestall depletion of food for the medusae and maintain constancy in this variable.

The diversity of the zooplankton community was altered in each of the three treatments. Diversity increased in the control, while the presence of medusae reduced the Shannon Diversity Index for zooplankton in both the high and low medusa density treatments. This finding suggests the possibility of changes not only in the density of zooplankton but also in their community structure and diversity when $C$. sowerbii blooms occur.

\section{Medusa Effects on Aquatic Food Webs}

Medusae presence and density have the potential to affect aquatic food web structure in several ways (Fig. 10). The zooplankton on which medusae feed are often the crucial link between primary producers and higher trophic levels (Williamson and Stoeckel, 1989; Brooks and Dodson, 1965; Carpenter and Kitchell, 1984), and thus medusae, particularly during jellyfish bloom events, may have both bottom-up and top- 
down cascading effects on aquatic food web structure and productivity. While medusae can kill small fish directly (Dodson and Cooper 1983 and personal observation), they can also affect zooplanktivorous fish indirectly by altering zooplankton densities. Dodson and Cooper (1983) found that their Craspedacusta sowerbii population killed both large predatory zooplankton (Leptodora sp.) and smaller predatory rotifers (Asplanchna sp.) that in turn feed upon very small rotifers, such as Keratella cochlearis and Brachionus angularis. The densities of small rotifers $K$. cochlearis and B. angularis actually increased in predation experiments, presumably due to the strong decline in Asplanchna, which feeds upon them (Dodson and Cooper 1983). This may have occurred in the current experiment in that Keratella sp. appear to have responded to release from predation by adult copepods. Therefore, medusa predation on other predators of zooplankton may cause substantial change in herbivorous zooplankton composition and density. Consequently, aquatic systems that experience a substantial bloom could be significantly altered through direct (predation) and indirect (reduction of zooplanktivores) top-down trophic effects.

While the current experiment estimates consumption rates, medusae also kill zooplankton that they do not necessarily consume, as shown in the previous chapter and by Smith and Alexander (2008). Such incidental mortality may result from the killing of prey that is too large for medusae to ingest or from the inability of medusae to successfully capture the prey. For example, copepods, while certainly consumed by medusae, may also be stung by nematocysts but then evade capture due to their ability to move quickly. If death occurs, the animal will sink to the bottom. In the current experiment, sampling was unable to distinguish between live and dead zooplankton due 
to mixing before sampling. Thus, feeding rates expressed are considered actual consumption rates and likely underestimate the effect of medusae on zooplankton densities.

\section{Other Ecosystem Effects}

There are other potential effects of varying medusal densities on primary production and nutrient cycling in freshwater systems. This potential has been observed in marine cnidarians, which have been found to have drastic effects on plankton production through the cycling of carbon $(\mathrm{C})$, nitrogen $(\mathrm{N})$ and phosphorus $(\mathrm{P})(\mathrm{Pitt}$, Welsh \& Condon 2009). Cnidarians acquire these nutrients through the consumption of zooplankton, just as $C$. sowerbii does, and then release them through excretion of inorganic (predominantly ammonium $\left(\mathrm{NH}_{4}{ }^{+}\right)$and phosphate $\left(\mathrm{PO}_{4}{ }^{3-}\right)$ ) and dissolved organic forms (e.g. dissolved amino acids and dissolved primary amines). This provides a significant proportion of the $\mathrm{N}$ and $\mathrm{P}$ used by phytoplankton for primary production. In addition, decomposition of medusa blooms may release large amounts of nutrients into a water body, which can in turn increase bacterial activity, potentially leading to temporary anoxic conditions, as well as eventually release of nutrients.

\section{Conclusions}

C. sowerbii exhibits several mechanisms by which it can impact zooplankton community structure and aquatic food webs: through direct predation of zooplankton (both consumed and killed), the top-down effect of altering the food available for zooplanktivorous animals, the bottom-up effect of increased primary production (both 
from removal of herbivorous zooplankton and increased inputs of nutrients) and the potential release of small zooplankton from predation by larger zooplankton that are consumed by the medusae. All of these have the potential to alter aquatic food webs when medusa blooms occur and then crash.

Future studies should measure the incidental mortality of zooplankton that are killed but not consumed in order to better estimate the effect of medusae on zooplankton populations. Additionally, estimates of nutrient inputs by medusae would be helpful in describing effects of C. sowerbii blooms on freshwater systems. Lastly, little work has been done to estimate the effect of $C$. sowerbii polyps, which also eat zooplankton. While the ratio of polyps to medusae may be low in terms of biomass and feeding rates, polyps are the dominant life stage of this species and have been reported to live more or less indefinitely (Dendy 1978). Thus polyps may have a longer-lasting effect on freshwater systems over the entire year.

C. sowerbii is a curious species that has for years intrigued the aquatic ecologists fortunate enough to find them. Despite the interest and enthusiasm for studying this species, the ephemeral nature of the medusae make consistent experimentation difficult. I greatly hope that the future will reveal more about this beautiful and fascinating cnidarian. 
Table 2. Zooplankton counts from the 2008 experiment. Number are prey liters ${ }^{-1}$ and are the average of three replicates for each treatment $\pm \mathrm{SE}$.

\begin{tabular}{|l|c|c|c|c|c|c|}
\cline { 2 - 7 } \multicolumn{1}{c|}{} & \multicolumn{3}{c|}{ Day 0 } & \multicolumn{3}{c|}{ Day 2 } \\
\hline & Control & Low & High & Control & Low & High \\
\hline Nauplii & $85 \pm 10$ & $80 \pm 5$ & $110 \pm 43$ & $108 \pm 7$ & $73 \pm 19$ & $7 \pm 1$ \\
\hline Copepods & $42 \pm 21$ & $25 \pm 18$ & $30 \pm 9$ & $69 \pm 12$ & $20 \pm 5$ & $1 \pm 1$ \\
\hline Keratella & $83 \pm 30$ & $96 \pm 28$ & $116 \pm 42$ & $149 \pm 11$ & $117 \pm 27$ & $127 \pm 28$ \\
\hline Polyarthra & $55 \pm 6$ & $75 \pm 6$ & $70 \pm 25$ & $143 \pm 12$ & $92 \pm 27$ & $13 \pm 3$ \\
\hline
\end{tabular}

Table 3. P-values from a mixed model ANOVA for treatment, day, and their interaction for the four groups present based on counts of total prey items per $20 \mathrm{~L}$ in tank for the 2008 experiment.

\begin{tabular}{|l|c|c|c|}
\cline { 2 - 4 } \multicolumn{1}{c|}{} & treatment & day & trt*day \\
\hline Copepods & 0.0003 & 0.78 & 0.14 \\
\hline Keratella sp. & 0.47 & 0.31 & 0.22 \\
\hline Nauplii & 0.012 & 0.005 & 0.019 \\
\hline $\begin{array}{l}\text { Polyarthra } \\
\text { sp. }\end{array}$ & $<0.0001$ & 0.105 & 0.0016 \\
\hline
\end{tabular}

Table 4. Shannon Diversity index for the 2008 experimental treatments.

\begin{tabular}{|l|r|r|}
\cline { 2 - 3 } \multicolumn{1}{c|}{} & \multicolumn{2}{c|}{$\begin{array}{c}\text { Shannon } \\
\text { Diversity }\end{array}$} \\
\cline { 2 - 3 } \multicolumn{1}{c|}{} & Day 0 & \multicolumn{1}{c|}{ Day 4 } \\
\hline Control & 3.85 & 3.96 \\
\hline Low & 3.66 & 3.32 \\
\hline High & 3.61 & 1.71 \\
\hline
\end{tabular}

Table 5. Zooplankton counts from the 2012 experiment. Number are prey liters ${ }^{-1}$ and are the average of three replicates for each treatment $\pm \mathrm{SE}$. 


\begin{tabular}{|l|c|c|c|c|c|c|}
\cline { 2 - 7 } \multicolumn{1}{c|}{} & \multicolumn{3}{c|}{ Day 0 } & \multicolumn{3}{c|}{ Day 2 } \\
\hline Control & Low & High & Control & Low & High \\
\hline Keratella & $112 \pm 41$ & $45 \pm 21$ & $42 \pm 5$ & $16 \pm 11$ & $9 \pm 3$ & $24 \pm 5$ \\
\hline Polyarthra & $4 \pm 3$ & $7 \pm 3$ & $4 \pm 2$ & $1 \pm 1$ & $2 \pm 0$ & $1 \pm 1$ \\
\hline Branchionus & $1 \pm 1$ & $1 \pm 1$ & 0 & 0 & 0 & 0 \\
\hline Nauplii & $5 \pm 3$ & $4 \pm 1$ & $7 \pm 4$ & 0 & $2 \pm 2$ & $1 \pm 1$ \\
\hline Copepods & $3 \pm 2$ & $2 \pm 1$ & $1 \pm 1$ & $5 \pm 2$ & $1 \pm 1$ & $1 \pm 1$ \\
\hline
\end{tabular}

Table 6. P-values from a mixed model ANOVA for the significance of the treatment, day and their interaction from the 2012 experiment.

\begin{tabular}{|l|c|c|c|}
\cline { 2 - 4 } \multicolumn{1}{c|}{} & trt & day & trt*day \\
\hline Branchionus sp. & 0.424 & 0.258 & 0.753 \\
\hline Nauplii & 0.067 & 0.957 & 0.231 \\
\hline Copepods & 0.249 & 0.001 & 0.092 \\
\hline Keratella $s p$. & 0.826 & 0.024 & 0.575 \\
\hline Polyarthra sp. & 0.557 & 0.005 & 0.902 \\
\hline
\end{tabular}

Table 7. P-values for starting densities of zooplankton prey groups in the 2012 experiment before medusa addition.

\begin{tabular}{|l|c|}
\cline { 2 - 2 } \multicolumn{1}{c|}{} & p-value \\
\hline Branchionus sp. & 0.5917 \\
\hline Nauplii & 0.8386 \\
\hline Copepods & 0.2156 \\
\hline Keratella sp. & 0.565 \\
\hline Polyarthra sp. & 0.739 \\
\hline
\end{tabular}




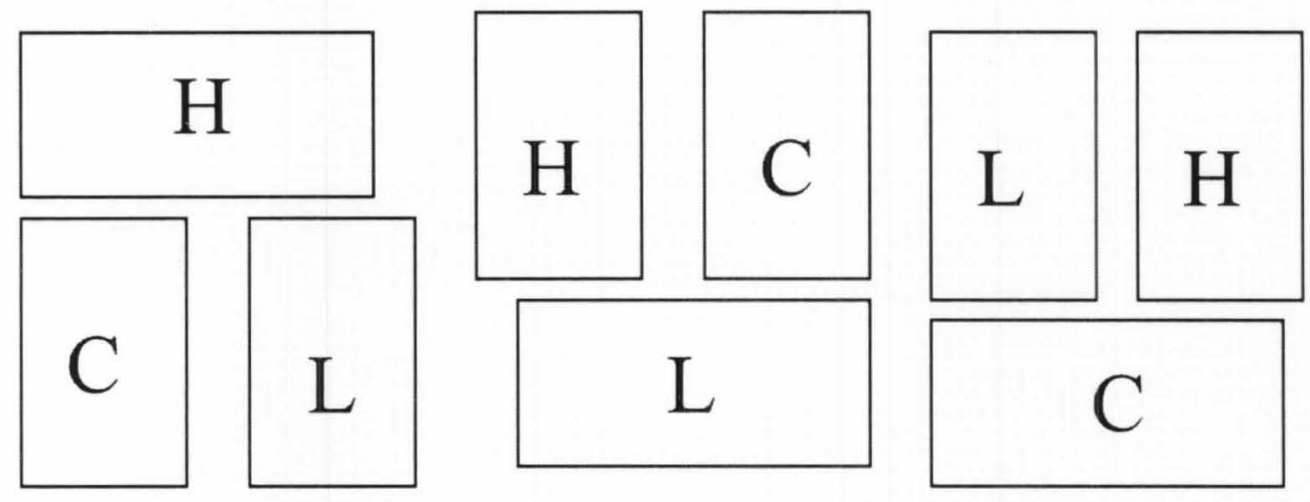

Figure 3. Experimental positioning of tanks in for 2008 jellyfish density experiment were stratified and consisted of tanks in three blocks each with three treatments. Control: C, Low Density (1 Medusa/tank): L, and High Density (10 medusae/tank): H.

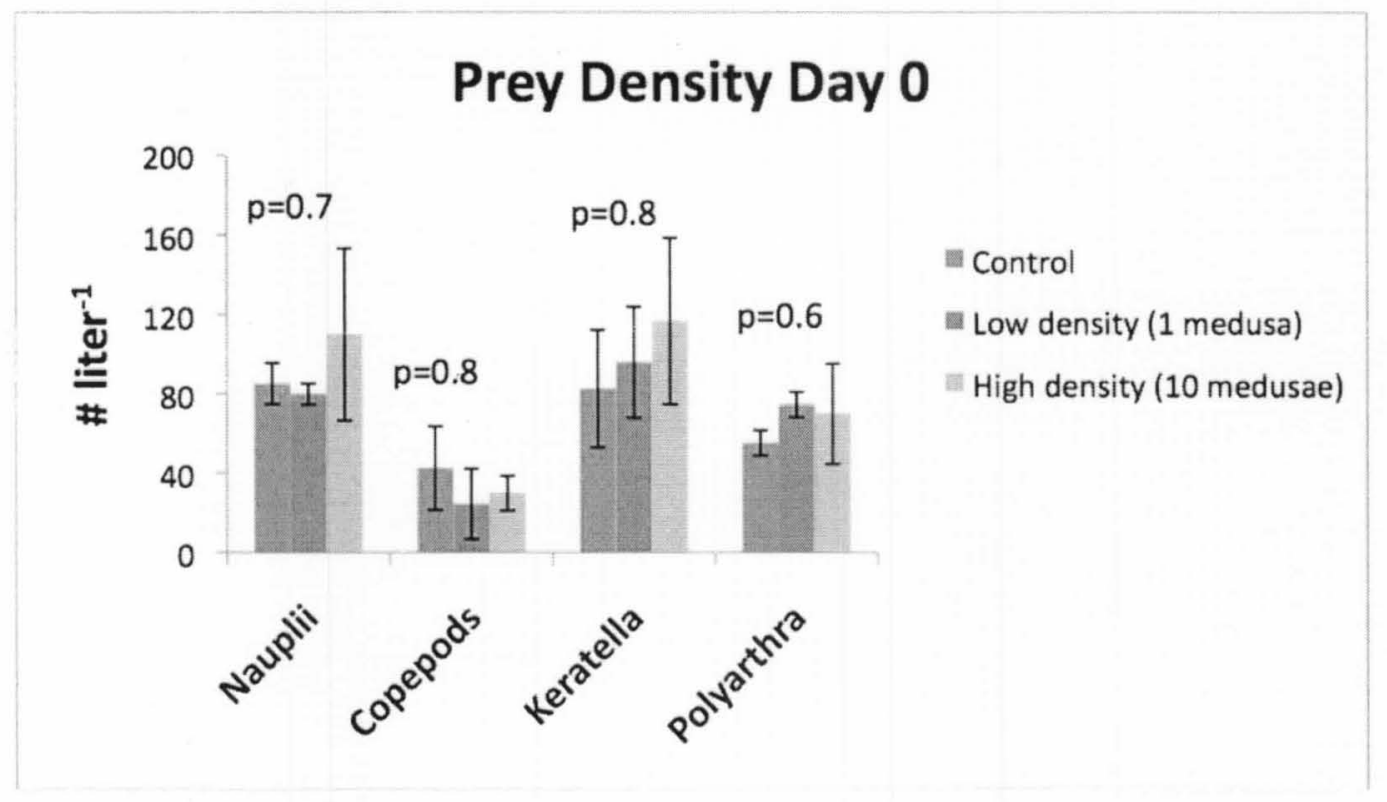

Figure 4. Mean starting densities ( \pm 1 S.E.) of prey items on day 0 before addition of medusae Tanks were later apportioned to three treatments: control (no medusa), low density (1 medusa), and high density (10 medusae). 


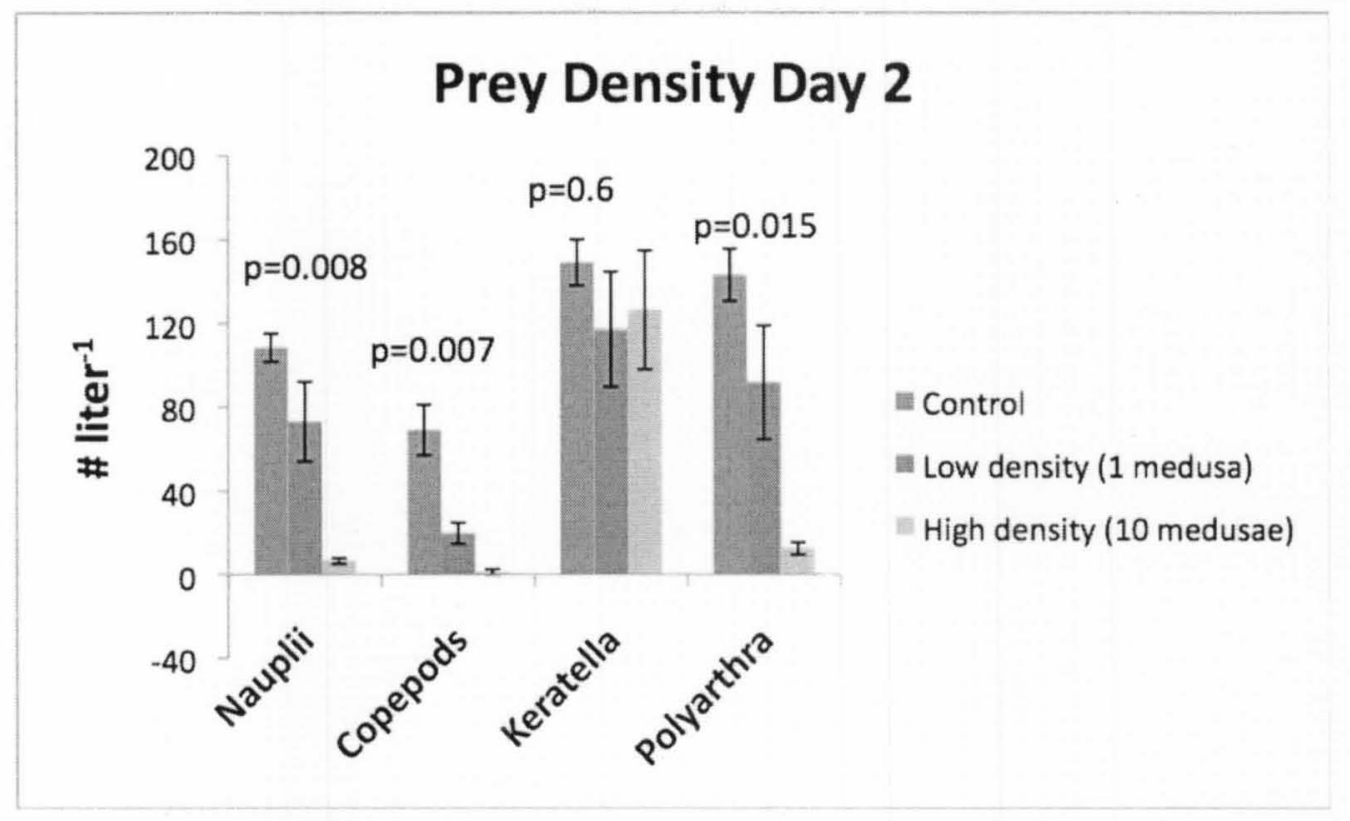

Figure 5. Mean density ( \pm 1 S.E.) of prey items after 2 days in each of three treatments: control (no medusae), low density (1 medusa), and high density (10 medusae).

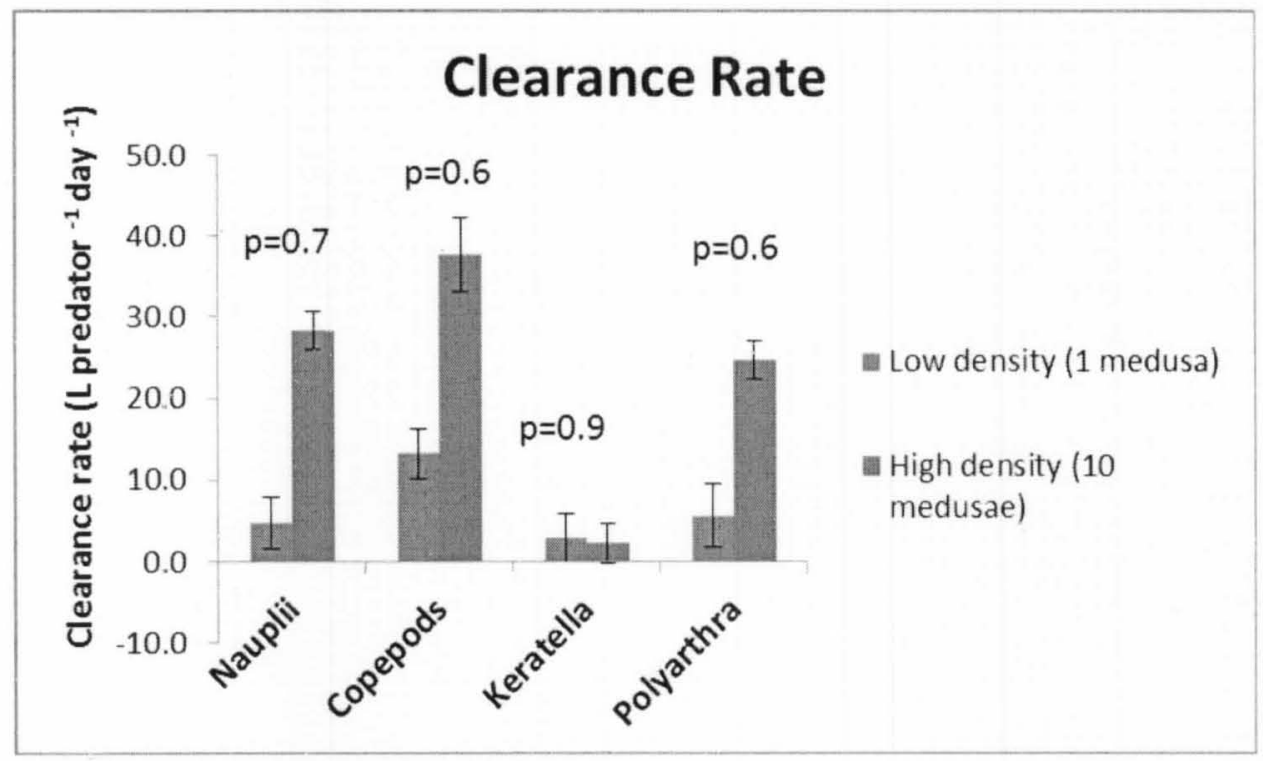

Figure 6. Comparison of clearance rates ( \pm 1 S.E.) expressed as liter predator ${ }^{-1}$ day $^{-1}$ in low density ( 1 medusa) and high density (10 medusae) treatments after 2 days. 


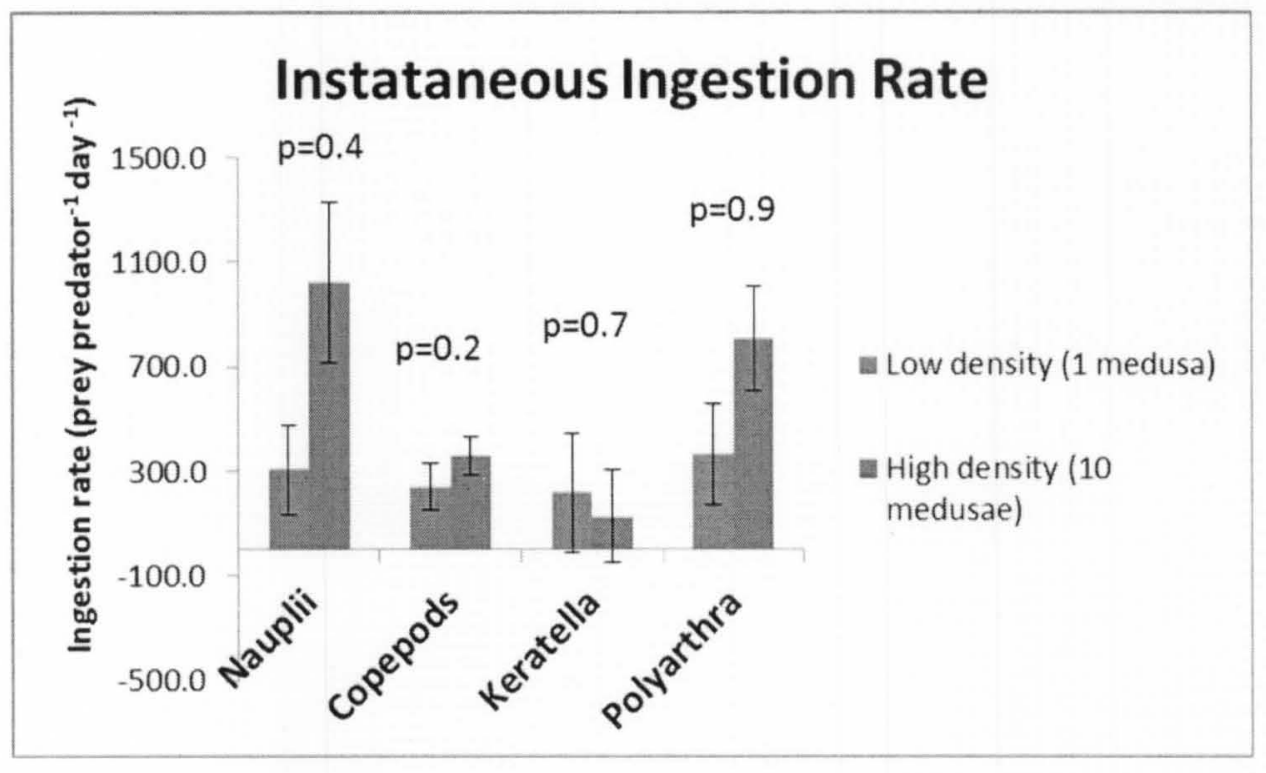

Figure 7. Comparison of instantaneous ingestion rates $( \pm 1$ S.E.) expressed as prey predator $^{-1}$ day $^{-1}$ in low density ( 1 medusa) and high density (10 medusae) treatments after 2 days.

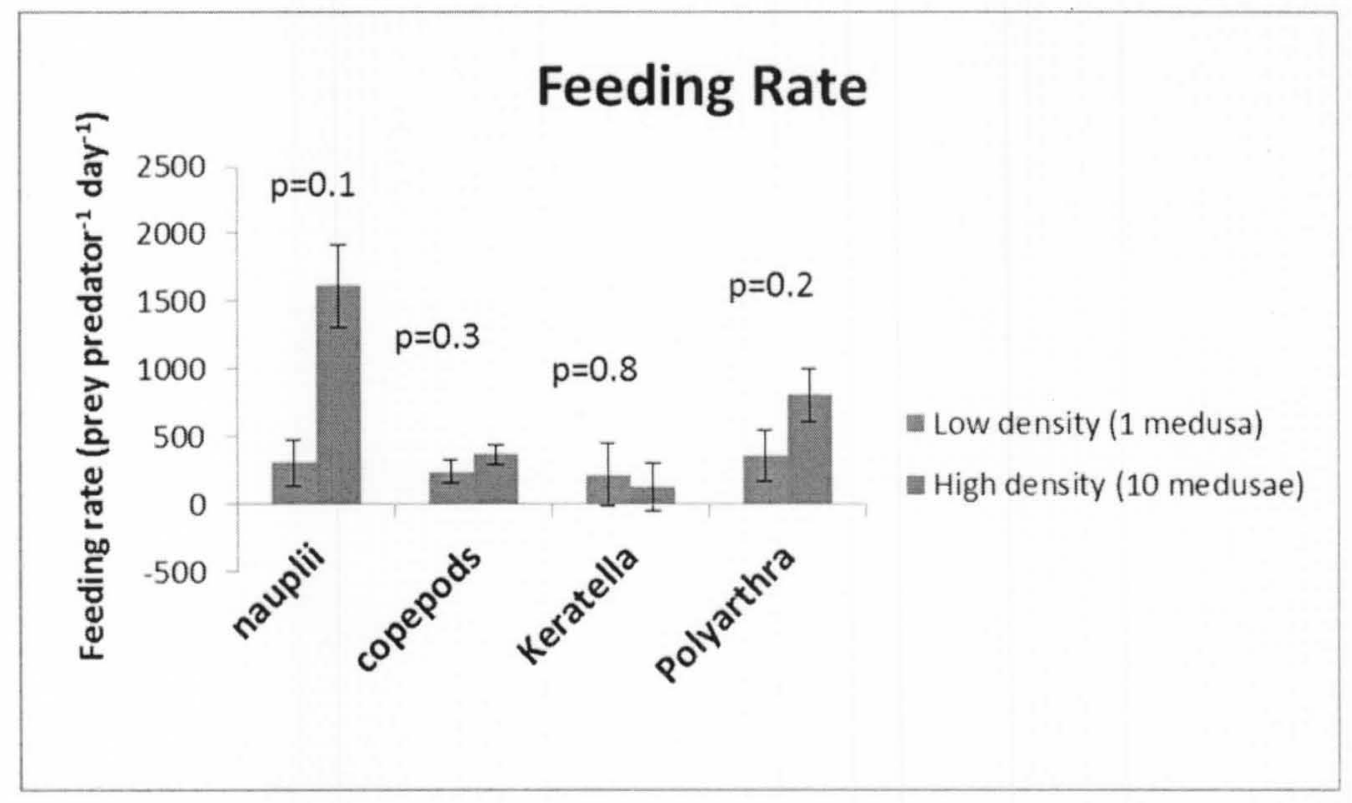

Figure 8. Comparison of feeding rates ( \pm 1 S.E.) expressed as prey predator ${ }^{-1}$ day $^{-1}$ in low density ( 1 medusa) and high density (10 medusae) treatments after 2 days. 
A.
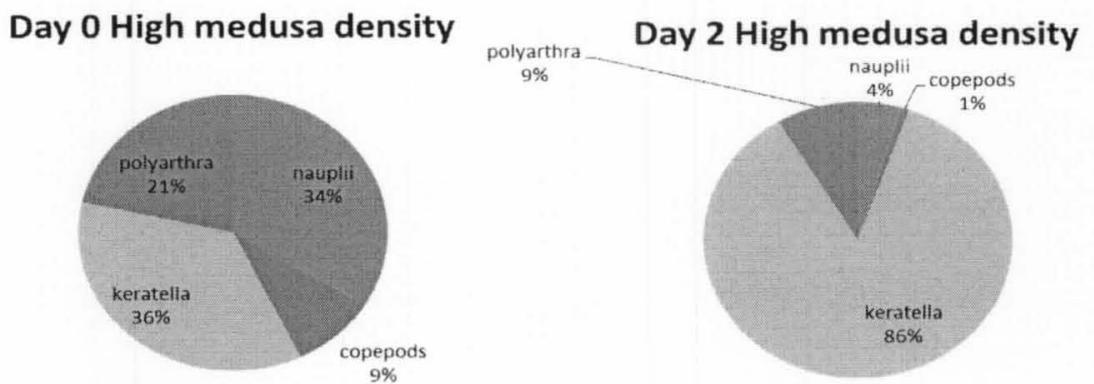

B.

\section{Day 0 Low medusa density}

Day 2 Low medusa density
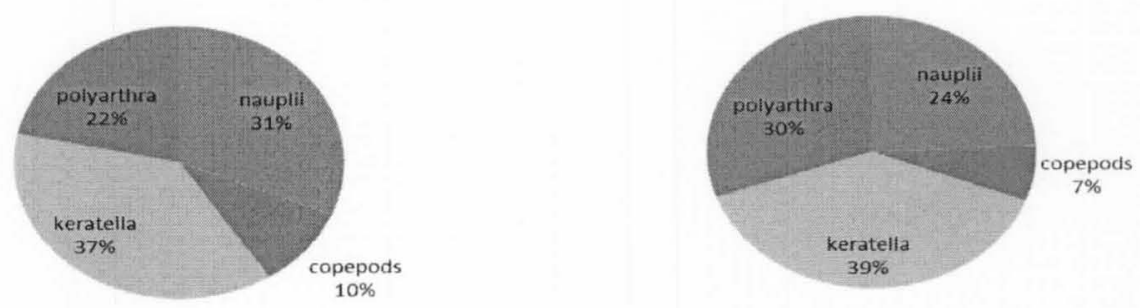

Figure 9. Prey groups by percentage in the high density treatment (10 medusae; A) and in the low density treatment ( 1 medusa; B) on days 0 and 2.

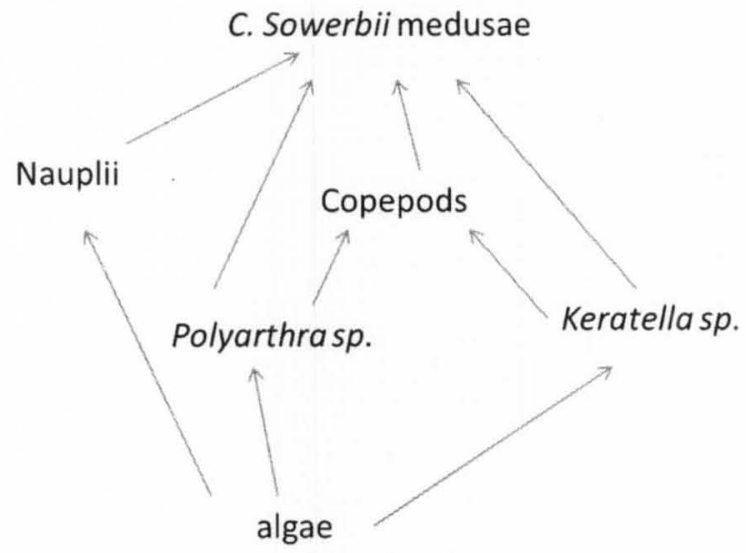

Figure 10. Food web diagram of animals found in the 2008 experiment. 


\section{CHAPTER 4: EFFECTS OF TEMPERATURE AND FOOD QUALITY ON DAPHNIA GROWTH AND REPRODUCTION}

Predicting how climate change will alter freshwater systems requires understanding the effects on the organisms that, in large part, dictate the structure of aquatic food webs. In many systems, zooplankton are the crucial link between primary producers and higher trophic levels of the food web (Williamson and Stoeckel, 1989; Brooks and Dodson, 1965; Carpenter and Kitchell, 1984). Zooplankton both regulate algal abundance (Mitchell and Lampert 2000) and act as a food source for zooplanktivores, such as larval insects and the young of nearly all fish species (Lampert and Sommer 2007). Zooplankton also play an important role in transferring algal- and heterotrophic protist-derived polyunsaturated fatty acids through the food web (Masclaux et al. 2012, Gladyshev 2009) as well as key macronutrients such as carbon (C), nitrogen $(\mathrm{N})$, and phosphorus $(\mathrm{P})$. As ubiquitous taxa, zooplankton are found in nearly all rivers, lakes, ponds, and streams. Thus zooplankton can serve as model organisms for understanding anthropogenic effects on many aquatic systems. In addition, Richardson (2008) found that responses of marine zooplankton phenology and distribution to a changing environment were greater and faster than those of terrestrial groups of plants and animals, making them important indicators of change and useful model systems for manipulative studies in the lab and field. 


\section{Daphnia as a model system}

Daphnia in particular have been used as models for aquatic research. "The large advantage of Daphnia over other biological model organisms is that its importance in pelagic freshwater systems is undoubtedly known. Hence there is a direct way of applying the results to ecological systems." (Lampert 2006, see also McCauley et al. 1990) Currently Daphnia are used in understanding the evolutionary biology of adaptation to novel environments (Williams, Dick and Yampolsky 2012) and thus can be especially useful in modeling freshwater food web responses to climate change. From an ecosystem function perspective, Daphnia are known to be important recyclers of $\mathrm{P}$ and can thus increase system productivity through increased rates of trophic transfer resulting from Daphnia's adaption to low food quality (Mulder and Bowden 2007, Sterner and Hessen 1994, Lampert 1987 and Sterner 1989 in Mitchell and Lampert 2000) and are responsible for both bottom-up and top-down effects on the food web (Gyllstrom et al. 2005). Due to its parthenogenetic lifestyle, ease of culturing (Seda \& Petrusek 2011), and short generation times (McCauley et al. 1990, Paul et al. 2004), Daphnia are wellresearched with a complete gene sequence including an online database, wFleaBase Daphnia Water Flea Genome Database (http://wfleabase.org/, Colbourne et al. 2005). Species in the cladoceran genus Daphnia may serve as important and useful model subjects for climate response studies, because they inhabit the majority of freshwater systems (Wojtal-Frankiewicz 2012), are poikilothermic with physiological processes that are highly sensitive to temperature (Richardson 2008) and display rapid microevolutionary responses to climate due to high genetic variation of egg banks (Van Doorslaer et al. 2009). In fact, many Daphnia-specific genes are particularly responsive 
to ecological change (Colbourne et al. 2011) and it would appear that climate warming is not a threat to the existence of Daphnia as a result of this great genetic variability (Wojtal-Frankiewicz 2012).

Within the Daphnia genus, Daphnia magna has been widely used as a model organism in aquatic ecology (Martinez-Jeronimo 2012, Smith 1963) to investigate modeling energy transfer through trophic levels (Schindler 1968), bacterial resistance (Ebert et al. 1998), and toxicological responses (Heijerick et al. 2002, Adema 1978, LeBlanc 1980). Daphnia pulex also has a long history of use in aquatic research for studying the transformation of energy (Richman 1958), bioaccumulation of polycyclic aromatic hydrocarbons (Southworth et al. 1978), ribosomal DNA variation (Crease and Lynch 1991), and a great many toxicity studies (Santore et al. 2001, Arnold 1971, Reinikainen et al. 1994, Govers et al. 1984, Walthall \& Stark 1999, Winner 1986, Southworth et al. 1978).

Use of the Daphnia genus in climate change research has the potential to help disentangle interacting effects that make such research complicated. These effects include warmer temperatures and potentially greater variation in macronutrient concentrations in freshwater bodies due to predicted extremes of drought and heavy precipitation in their watersheds (Solomon et al. 2007, Kundzewicz et al. 2007). Therefore, their long history in aquatic research, as well as their known propensity for rapid microevolutionary change, make Daphnia a promising model system for understanding how changing temperature and macronutrient limitation may alter aquatic food webs.

Direct effects of temperature on Daphnia physiology 
While there are no known thermoreceptors or defined thermoregulatory centers in crustaceans such as Daphnia spp. (Lagerspetz \& Vainio 2006), zooplankton display distinct and easily measured physiological responses to temperature (Lagerspetz \& Vainio 2006). The van't Hoff rule (Lampert and Sommer 2007) states that within the temperature growth and tolerance range for a species, the rate of chemical and biological reactions increases two-fold for every $10^{\circ} \mathrm{C}$ rise in temperature. Above and below the range in which the van't Hoff rule applies, the rate of respiratory movements and heart beat in Daphnia decreases abruptly leading to an impairment in the delivery of oxygen to cells (Lagerspetz \& Vainio 2006). In fact, Daphnia acclimated to higher temperatures show changes in hemoglobin concentration, subunit composition and oxygen affinity as a result of higher metabolic demands (Gerke et al. 2011). They also contain lower levels of highly unsaturated fatty acids, which regulate cell membrane physiology, allowing for greater membrane fluidity at higher temperatures, and are precursors for many hormones that are linked to growth and reproduction (Gladyshev et al. 2011, Wojtal-Frankiewicz 2012, Brett and Müller-Navarra 1997). Above the preferred temperature range for growth and reproduction, respiratory activity continues nonetheless to increase despite its uncoupling from growth (Goss and Bunting 1983, Paul et al. 2004). To compensate for the decrease in oxygen delivery to cells at higher temperatures, swimming speed increases klinokinetically (i.e., random movement increases) and the rate of filtration increases (Moore et al. 1996). In order for increased locomotion and respiration to occur, greater production of ATP is required, and allocation of ATP to growth may subsequently decrease (Wojtal-Frankiewicz 2012). 
What temperatures are D. magna and D. pulex exposed to in their natural geographic range?

Populations of Daphnia pulex species complex can be found in both Arctic and temperate habitats (Elser et al. 2000). While Martinéz-Jeronimo (2012) found in lab experiments that D. magna exhibited the highest growth rate at $25^{\circ} \mathrm{C}$, he states that it is only found infrequently in waters where temperatures rise above $20^{\circ} \mathrm{C}$. Others, however, claim that D. magna can commonly be found in shallow ponds where temperatures can fluctuate between $<15$ and $30^{\circ} \mathrm{C}$ (Persson et al. 2011), indicating a wide thermal tolerance (Mitchell and Lampert 2000) as well as an ability to tolerate high temperatures and low oxygen concentration (MacIsaac et al. 1985).

\section{Effects of nutrient availability}

Growth rate of Daphnia is also determined by the availability and quality of food, although abiotic factors can also be important as mentioned above (e.g., Acharya et al. 2004). Phosphorus (P) and nitrogen $(\mathrm{N})$ levels have been shown to influence food quality for freshwater zooplankton (Elser et al. 2001). Daphnia, in particular, have relatively high $\mathrm{P}$ requirements resulting in a low $\mathrm{C}: \mathrm{P}$ ratio compared to other zooplankton such as copepods (Sterner \& Hessen 1994). For example, Daphnia growth has been shown to correlate with algal P content when food P is low (Gulati \& Demott 1997, Acharya et al. 2004), while P supplementation experiments have shown that at least some of the reduction in growth is a direct result of P deficiency (DeMott et al. 1998, Boersma \& Kruetzer 2002, Elser, Hayakawa \& Urabe 2001). Biochemical requirements for $\mathrm{P}$ include production of nucleic acids, ATP-ADP, and phospholipids. RNA can be up to $10 \%$ of Daphnia dry mass, possibly accounting for its high P demand. Thus, Daphnia's 
high demand for P relates to its high growth rate (Sterner \& Hessen 1994). This has been stated in the Growth Rate Hypothesis, which posits that RNA content is positively correlated with growth rate (Sterner and Elser 2002). The legitimacy of this hypothesis has been explored by Elser et al. (2000) who cultured $D$. pulex from Alaska and Wisconsin and found that D. pulex from Alaska had higher $\mathrm{P}$ demands than their conspecifics in Wisconsin, presumably due to the shorter growing season in northern latitudes that requires higher rates of growth in a shorter period of time and thus more demand for $\mathrm{P}$. In addition to growth rate, $\mathrm{P}$ availability also affects age at first reproduction, reproductive output, adult body size and other key aspects of species' life history (Arendt 1997).

Unlike primary producers, animals in general lack high capacity for mineral storage when minerals are in excess and therefore are at risk of mineral limitation when their food is of low nutritional quality (Sterner \& Hessen 1994). Until recently it was thought that while primary producers could vary their $\mathrm{C}: \mathrm{N}: \mathrm{P}$ based on the concentration of nutrients available, animals in general maintained a constant $C: N: P$ regardless of the stoichiometry of their food. While the "strict homeostasis" of animals, has been invalidated, analyses show that invariant $C: N: P$ in herbivores can still occur under low nutrient conditions (Wang et al. 2012).

\section{Interactive Effects of Temperature and Food Quality}

Understanding the interaction between temperature and food quality can be important in predicting how Daphnia will respond to climate change, food resources stratified by thermocline (Cole et al. 2002), and nutrient limitation (Persson et al. 2011). 
The ability of Daphnia to adapt to changing climate, with associated changes in temperature, precipitation and food quality, may well have critical consequences on ecosystems by limiting energy transfer to higher trophic levels (Winder and Schindler 2004).

Only three previous studies could be found that experimentally tested the interaction of food quality and temperature on Daphnia. Persson et al. (2011) found that D. magna was at increased risk of phosphorus limitation at higher temperatures $\left(25^{\circ} \mathrm{C}\right)$, since P limitation levels vary with temperature. They found that while P limitation was problematic at higher temperatures, at low temperatures enzyme kinetics or other aspects of food quality were of greater concern than P limitation. Pajk et al. (2012) found a strong positive effect of temperature on D. magna and D. pulex juvenile growth rate with higher growth rates at $20^{\circ} \mathrm{C}$ compared to $15^{\circ} \mathrm{C}$. Lastly, McFeeters and Frost (2011) found a strong interactive effect of temperature and food quality for D. magna growth and respiration but not for $D$. pulex at temperatures ranging from $10-25^{\circ} \mathrm{C}$.

In a series of laboratory experiments, I sought to explore potential interactions between temperature and food quality on the growth and reproduction of two species of Daphnia varying in adult size, life history traits, and temperature optima by varying growth temperatures and the quality of algal food grown under high and low $\mathrm{N}$ and $\mathrm{P}$ conditions. Lampert and Trubetskova (1996) found that juvenile growth rate could be used as a measure of relative fitness in Daphnia. I measured the fecundity and growth rate to assess their responses to altered environmental conditions.

\section{Methods}

\section{Organisms and Algae}


D. pulex individuals were obtained from The Center for Genomics and Bioinformatics at Indiana University and D. magna from Carolina Biological Supply Company (Burlington, NC). Animals were examined at 25x using Thorp and Kovich (1991) to ensure the species identification. Both are common and important species in temperate freshwater systems of North America. Animals were established in stock cultures and maintained at room temperature on high quality food at high levels $(>1.5 \mathrm{mg}$ $\mathrm{C} / \mathrm{L}$ ). The carbon concentration of the algae in the Daphnia growth medium was determined by spectrophotometrical analysis of chl a (Acharya et al. 2006). Laboratory experiments were conducted on neonates of approximately the same age from a clonal line to avoid confounding effects of genetic differences between clones. Animals born to a single mother (one clonal line) were isolated and grown individually in 250 -mL flasks and fed a high-concentration (>1.5 $\mathrm{mg} \mathrm{C} / \mathrm{L}$ ) of the alga, Scenedesmus acutus, and transferred to fresh media and fed every 3-5 days. Offspring of these animals (third generation) were allocated individually into their own flasks until there were enough animals in each flask to provide the required number of offspring for experiments. These animals (fourth generation) were fed and transferred to fresh flasks at regular intervals (every 3-5 days) and neonates ( $<24$ hours old) from the second and subsequent clutches of the fourth generation and later were used for the experiments. Subsequent offspring were maintained as described above for the duration of the experiments in order to provide experimental animals.

The alga, Scenedesmus acutus, was grown in batch cultures under two conditions of nutrient supply in an environmental chamber at $25^{\circ} \mathrm{C}$. Nutrient-rich algae were grown in autoclaved tap water modified (Kent Marine Pro-Culture Parts A and B) to contain a 
final concentration of $1000 \mu \mathrm{MN}$ (in the form of $\left.\mathrm{NaNO}_{3}\right)$ and $50 \mu \mathrm{MP}\left(\mathrm{P}_{2} \mathrm{O}_{5}\right)($ molar N:P 20, C:P 100-200) in batch cultures at 12:12 hours of light:dark. Nutrient-poor algae were grown on filtered and autoclaved Paramount Lake water (an oligotrophic lake in Oldham County, Kentucky; $\left.38^{\circ} 23^{\prime} 1.60^{\prime \prime} \mathrm{N}, 85^{\circ} 34^{\prime} 25.93^{\prime \prime} \mathrm{W}\right)$ modified to contain a final concentration of $500 \mu \mathrm{M} \mathrm{N}$ and $5 \mu \mathrm{M} \mathrm{P}$ (molar N:P 100, C:P 500) and grown under high light conditions (Acharya et al. 2006) at 12:12 hours light:dark.

\section{Determination of algal $C, N$ and $P$ content}

Samples of algae were collected throughout the experiment, placed in tins, and dried at $45^{\circ} \mathrm{C}$. These samples were stored in a desiccator before $\% \mathrm{CHN}$ analysis took place using a Perkin Elmer Model 2400 (Waltham, MA). Additional samples were placed in plastic test tubes and frozen for total $\mathrm{P}$ analysis using the automated ascorbic acid reduction method (Eaton et al. 1995) on a Skalar SAN Plus System (Breda, The Netherlands) segmented flow analyzer (for P content). Algae grown under high nutrient conditions had a molar CNP ratio that ranged from 8:5:1 to 50:26:1 and those grown at low nutrient conditions had $\mathrm{C}: \mathrm{N}: \mathrm{P}$ that ranged from $554: 364: 1$ to $1745: 90: 1$.

\section{Growth Rate Experiment}

This experiment examined the interactive effects of temperature and food quality on the somatic growth rate of two species of Daphnia. To conduct this experiment, a large cohort of neonates were collected as described above and placed individually in 150 $\mathrm{mL}$ of filtered Ohio River water in a $250 \mathrm{~mL}$ Erlenmeyer flask. There were a total of 16 treatment combinations $(2 \times 2 \times 4)$ : two qualities of the alga, Scenedesmus, grown with high levels of nutrients ( $\mathrm{N}$ and $\mathrm{P})$ vs. low levels, two zooplankton species (D. magna or D. pulex) and four temperatures $\left(10,15,20\right.$, and $\left.25^{\circ} \mathrm{C}\right)$. There were at least 10 replicates 
for each treatment and each experiment lasted for three days in one of two Percival incubators that regulated temperature to within $1^{\circ} \mathrm{C}$ of the set temperature. The temperature variation was recorded using Hobo temperature data loggers (Onset Computer Corp., Bourne, MA) placed in the incubators. Treatments were maintained in complete darkness to prevent uncontrolled growth of algae. While the experiment was running, images were captured of additional neonates ( $<24$ hours old) born from the clonal line kept in culture on their day of birth for use in the calculation of growth rate. Over the course of the experiment, newborn animals were placed in one of the 16 treatments. On day 2 , the animals were transferred to a clean flask with fresh algae. On day 3 , the animals were sacrificed to capture their final image for size change over the 3 day interval (growth). Since juvenile growth stops when reproduction begins, a 3-day interval was used in order to measure growth rate before energy is allocated to reproduction. An Olympus BX51 TRF at $25 \mathrm{x}$ was used together with image analysis software JMicrovision 1.2.7 (Geneva, Switzerland) to determine the area of the animals on day 0 and day 3 . Somatic growth rate was then calculated using the equation

$$
\mathrm{r}=\underline{\ln (\text { final area/initial area) }}
$$

\section{Fecundity}

In a separate but related experiment, animals less than 24 hours old from the second clutch of a clonal line were placed in one of the same 16 treatments used for the growth rate experiment for a longer-term fecundity experiment to measure the interactive effect of food and temperature on reproduction. Animals were placed individually in a flask containing $150 \mathrm{~mL}$ of filtered Ohio River water and fed an excess of either low or 
high quality food. Animals were transferred to fresh media every fourth day and fed fresh food every other day. Animals were examined individually each day. If a molt was detected, the date was recorded and the molt removed. If offspring were present, the date and clutch size was recorded and the experimental animal was transferred to fresh media. This continued until the 3 rd clutch was recorded. When animals died before the $3^{\text {rd }}$ clutch, the date was recorded so that mortality could be calculated for each treatment.

\section{$\underline{\text { Statistics }}$}

To compare the effects of temperature and food quality and their interaction on the growth rate of Daphnia magna and Daphnia pulex, a two-way ANOVA (SAS 9.3.1) was used with treatments (temperature and food quality) as fixed effects (alpha 0.05). Response variables were growth rate per day of animals. Post-hoc analysis was performed using contrasts to determine which specific treatments differed from one another.

Differences in fecundity among treatments were assessed using a two-way ANOVA (SAS 9.3.1) by testing the effects of food quality, temperature, and their interaction on clutch size, days to first clutch, molts to first clutch, and days to third clutch. The statistical difference between high and low quality food on these fecundity measures was tested for significance at each temperature (alpha 0.05).

\section{Results}

Growth Rates

D. magna 
Temperature, food quality and their interaction all affected the somatic growth rate of D. magna. Somatic growth rate (Fig. 11) was highest for D. magna at $30^{\circ} \mathrm{C}$ on high food quality $\left(0.66 \pm 0.04 \mathrm{day}^{-1}\right)$ and was lowest at $10^{\circ} \mathrm{C}$ on high food quality $(0.12 \pm$ 0.02 day $\left.^{-1}\right)$. At the two highest temperatures $\left(25\right.$ and $\left.30^{\circ} \mathrm{C}\right)$, growth rate was higher on high food quality but this difference was only significant at $25^{\circ} \mathrm{C}(\mathrm{p}<0.0001)$.

\section{D. pulex}

Growth rates for D. pulex (Fig. 12) were significantly affected by the interaction of temperature and food quality $(\mathrm{p}<0.0001)$. Somatic growth rate was highest for $D$. pulex at $20^{\circ} \mathrm{C}$ on high food quality $\left(0.38 \pm 0.02\right.$ day $\left.^{-1}\right)$ and was lowest at $10^{\circ} \mathrm{C}$ on low food quality $\left(0.04 \pm 0.02 \mathrm{day}^{-1}\right)$. When comparing growth rate between food qualities at each temperature, high quality food always resulted in a higher growth rate than low quality food, and the differences were statistically significant at all except the highest $\left(30^{\circ} \mathrm{C}\right)$ and the lowest $\left(10^{\circ} \mathrm{C}\right)$ temperatures. The difference in growth rate of animals fed high quality versus low quality food were highly significant $(\mathrm{p}<0.0001)$ at 15,20 , and $25^{\circ} \mathrm{C}$.

\section{Mortality and Fecundity}

At all four temperatures tested, mortality rates for D. magna were higher under conditions of low food quality (Table 8). Across the range of temperatures, mortality was highest $(100 \%)$ at $10^{\circ} \mathrm{C}$ on low food quality. All animals in this treatment died before producing offspring. The lowest mortality was $20 \%$ at $15^{\circ} \mathrm{C}$ on high quality food.

Mortality for $D$. pulex was highest $(90 \%)$ at $10^{\circ} \mathrm{C}$ on food of low quality (Table 9). Despite consumption of high quality food, percent mortality at $25^{\circ} \mathrm{C}$ was also high 
$(63 \%)$. All other mortality rates were below $50 \%$. The lowest mortality rate occurred at $20^{\circ} \mathrm{C}$ on high quality food $(5 \%)$.

\section{Days and molts to first clutch}

There was no significant interaction effect between food quality and temperature on days to first clutch for D. magna. Food quality only had a significant effect at $25^{\circ} \mathrm{C}$, where animals on high food quality took on average $11.7 \pm 0.87$ days to produce their first clutch, while animals on low food quality only took on average $8.4 \pm 0.20$ days (Fig. 13), possibly as a result of the animals on low quality food having a smaller body size and therefore faster reproduction. The earliest clutch occurred after 8 days at $25^{\circ} \mathrm{C}$ on low food quality. At $10^{\circ} \mathrm{C}$ on high food quality, the two surviving animals produced a first clutch after $50.5 \pm 0.5$ days. The number of molts before production of the first clutch only varied significantly at $25^{\circ} \mathrm{C}$ ( $\mathrm{p}<0.0001$; Fig. 14) where animals on high quality food produced $6.2 \pm 0.37$ molts before producing a first clutch, while animals on low quality food produced only $4.8 \pm 0.35$. There was, however, a highly significant interaction between food quality and temperature $(\mathrm{p}<0.0001)$ with the $20^{\circ} \mathrm{C}$ treatment having more molts before production of the first clutch than either $15^{\circ} \mathrm{C}$ or $25^{\circ} \mathrm{C}$.

The number of days required for $D$. pulex to produce a first clutch of offspring differed when animals were fed food of different quality (Fig. 15). At $15^{\circ} \mathrm{C}, \mathrm{D}$. pulex grown on high quality food took longer to produce a first clutch $(28.1 \pm 2.4$ days $)$ than when they grew on low quality food $(17.5 \pm 1.2$ days $)$; however, at $20^{\circ} \mathrm{C}$ animals grown on low quality food took longer $(11.3 \pm 0.37$ days $)$ to produce a first clutch than when 
grown on high quality food $(9.4 \pm 0.36$ days $)$. At $25^{\circ} \mathrm{C}$, animals fed low quality food took $7 \pm 0$ days to produce a first clutch while those grown on high quality food only took $6.3 \pm 0.33$ days. At $10^{\circ} \mathrm{C}$, there was no significant difference between days to first clutch based on food quality $(p=0.0937$; Fig. 5). There was a strong interaction effect between food quality and temperature $(\mathrm{p}=0.0007)$ with a strong decreasing trend for the number of days to produce the first clutch as temperatures increased from $10^{\circ} \mathrm{C}$ to $25^{\circ} \mathrm{C}$. No interactive effect between food quality and temperature on the number of molts produced by $D$. pulex before the first clutch was observable $(\mathrm{p}=0.393)$. The effect of differing food quality on number of molts before first clutch was not statistically discernible at any temperature (Fig. 16).

\section{Days to third clutch}

There was no significant interaction between food quality and temperature on the number of days it took $D$. magna to produce a third clutch ( $\mathrm{p}=0.825$; Fig. 17), although there was a decreasing trend in this life history trait as temperature rose from $15^{\circ} \mathrm{C}$ to $25^{\circ} \mathrm{C}$.

However, at $25^{\circ} \mathrm{C}$ the time interval between the second and third clutch did depend on food quality ( $\mathrm{p}=0.0002$ ), as animals on low food quality produced a third clutch after only $13.4 \pm 0.31$ days but animals on high quality food took $16.2 \pm 0.53$ days.

The number of days $D$. pulex took to produce a third clutch had a significant interaction effect between food quality and temperature $(p=0.001)$ with a strong decreasing trend from $10^{\circ} \mathrm{C}$ to $25^{\circ} \mathrm{C}$. The intermediate temperatures of $15^{\circ} \mathrm{C}(\mathrm{p}=0.0003)$ and $20^{\circ} \mathrm{C}(\mathrm{p}=$ 0.004) varied significantly between food qualities for days to reach the third clutch (Fig.

18). At $15^{\circ} \mathrm{C}$, there was almost a 10 day difference between days to produce a third 
clutch (low quality food: $27.3 \pm 1.3$ days; high quality food: $37.5 \pm 1.1$ days), while at $20^{\circ} \mathrm{C}$ there was a small but still statistically detectable difference between the two food qualities (low quality food: $17.7 \pm 0.57$ days; high quality food: $15.4 \pm 0.45$ days; $\mathrm{p}=$ $0.004)$.

\section{Days between clutches and clutch size}

Food quality had no statistically detectable effect on days between clutches for D. magna at any temperature. No interaction between food quality and temperature on this characteristic was observed $(\mathrm{p}=0.442$; Fig. 19), although there was a general trend of decreasing time to third clutch as temperature increased from $15^{\circ} \mathrm{C}$ to $25^{\circ} \mathrm{C}$. Clutch size (Fig. 21) depended on food quality at $15^{\circ} \mathrm{C}(\mathrm{p}=0.0002)$ and $25^{\circ} \mathrm{C}(\mathrm{p}=0.0026)$ and was inversely related to time between clutches. In addition, there was a significant interaction effect between food quality and temperature $(p=0.0029)$ on clutch size.

For D. pulex, food quality and temperature interacted to affect the between-clutch duration period $(\mathrm{p}=0.026)$. However, temperature had a stronger main effect on this characteristic than food quality ( $p<0.0001$ vs. $p=0.028$ ), since days between clutches decreased isotonically from $10^{\circ} \mathrm{C}$ to $25^{\circ} \mathrm{C}$ (Fig. 21). While there was no significant interaction effect between food quality and temperature $(\mathrm{p}=0.222)$ on clutch size, food quality (Fig. 22) affected clutch size at $15^{\circ} \mathrm{C}(\mathrm{p}=0.002)$ and $20^{\circ} \mathrm{C}(\mathrm{p}<0.0001)$ where $D$. pulex fed high quality food produced more offspring per clutch compared to animals in the low quality food treatment. 


\section{Discussion}

These experiments sought to highlight the effects of temperature and food quality on growth and reproduction of two common species of Daphnia by measuring growth rate and fecundity across a range of temperatures and feeding them either high or low quality food. The results show that $D$. pulex and D. magna reproduced more quickly at higher temperatures, confirming earlier work with these species (Orcutt and Porter 1983, Malin and Parton 1989). Previous research also indicates that D. pulex goes through fewer molts than D. magna before reproducing for the first time (Goss and Bunting 1983), and the current results support this with D. magna molting $5.7 \pm 0.6$ times before reproduction when averaged across all temperatures and $D$. pulex molting an average of $3.8 \pm 0.4$ times. Such differences would be expected based on the body size of these two daphnids. D. pulex is smaller and thus would be expected to grow and reproduce more quickly than the larger D. magna.

The current results give insight into the temperature preferences of $D$. pulex and D. magna. While $D$. pulex's growth rate peaked at $20-25^{\circ} \mathrm{C}$ and then declined at $30^{\circ} \mathrm{C}$, D. magna's growth rate was still increasing at $30^{\circ} \mathrm{C}$, indicating that the top of its temperature range had not been reached. As global warming continues to affect temperate fresh waters, such temperature tolerances may play an important role in determining where species can survive. As temperatures have increased, warm-water species have been found in waters that were once too cold to sustain them. This also has implications for the spread of exotic species that may be better suited to warmer temperatures than many natives.

The findings in this study have implications for understanding the interactive 
effect of food quality and temperature on Daphnia growth and reproduction. For example, D. pulex showed strong responses to food quality at intermediate temperatures $\left(15-25^{\circ} \mathrm{C}\right)$ compared to the highest $\left(30^{\circ} \mathrm{C}\right)$ and lowest $\left(10^{\circ} \mathrm{C}\right)$ temperatures tested in this study. This implies that $D$. pulex is more strongly affected by food quality at intermediate temperatures but as temperature increases or decreases outside of this range enzyme kinetics have a stronger effect on growth. As temperature increases, not only does growth rate increase but also respiration and cellular activity. Higher growth rates at higher temperatures may also affect what nutrients are in the highest demand. Faster growth requires increased allocation of phosphorus to RNA in order to maximize growth, but this increased growth rate may be accompanied by a reduction in body protein, thus lowering nitrogen requirements (Elser 2000). In addition, D. pulex had fewer molts before their first clutch of offspring at higher temperatures despite their higher growth rate. Thus, they grew faster but for a shorter period of time. This can result in a smaller adult body size, which may affect Daphnia predation risk since large-bodied animals are favored when the predators are small. Thus, responses to food quality and temperature may alter Daphnia's fitness not only through effects on reproduction but on survivorship as adults as well.

It should be noted that difference in chemical composition of algal food was not measured. It is possible that differences in treatment temperature altered the fatty acid composition of food after it was added to flasks containing experimental animals. Such changes in fatty acid composition can affect cellular membrane composition of consumers and may have influenced the effect of low quality food in these experiments.

Temperature Effects on Daphnia Growth Rate, Development and Reproduction 
Within a species-specific range, growth responds positively to increasing temperature for all ectotherms (Arendt 2010). Higher temperature increases the rate of biochemical activity and thus the rate of physiological reactions involved in growth. However, temperatures beyond a species-specific optimum may also lead to decreased growth rate and increased mortality. Perhaps as a compensatory reaction to decreased survivorship and therefore fecundity, remaining zooplankton in the population have been observed to reach adulthood and reproduce more quickly in lab settings (Orcutt and Porter 1983, Lei and Armitage 1980), possibly as a result of reduced food limitation when mortality is high. The number of molting events or instars occurring before reaching adulthood was found to be regulated mostly by temperature in Daphnia pulex (Lynch 1989). Studies of $D$. pulex and D. magna grown in environmental chambers at temperatures ranging from 5 to $30^{\circ} \mathrm{C}$, found the number of juvenile instars (or number of molting events) before reaching adulthood increased above $25^{\circ} \mathrm{C}$, while overall development time to reach adulthood was significantly shorter at higher temperatures (Goss and Bunting 1983 but see Orcutt and Porter 1983). The current study found a nonsignificant trend in $D$. pulex of decreased molts to first clutch but both species showed the expected increase in growth rate at higher temperatures up to an optimum temperature (Pangle \& Peacor 2010, Mitchell \& Lampert 2000). In addition, reproductive parameters responded strongly to increased temperatures: age at onset of reproduction and brood duration all were inversely related to temperature (Orcutt \& Porter 1983). For D. pulex, age at first reproduction has been found to occur sooner at higher temperatures with the highest rates of reproduction at $24^{\circ} \mathrm{C}$ and $27^{\circ} \mathrm{C}$ (Craddock 1975) despite high levels of mortality. However, in the current study, food quality was found to differentially affect 
how quickly $D$. pulex reproduced, with the strongest effects at above $15^{\circ} \mathrm{C}$.

Life stages are also differentially sensitive to temperature. Daphnia are most physiologically sensitive to temperature 2 to 6 days after birth, when rapid somatic development is occurring. However, one review found young zooplankton to be better adapted to warmer temperatures than older life stages (Ivleva 1969 in Craddock 1975). In addition, Ivleva (1969) found studies that indicated that when Daphnia are acclimated to higher temperatures for a long period they become less vulnerable to further increases in temperature (acclimation) within physiological limits. Temperature increases can even induce cyclomorphosis (i.e., production of defense mechanisms such as helmets and spines in offspring to reduce predation) in some species, possibly as a proximate cue for the presence of young of the year fish that emerge during warmer weather (Yurista 2000) and feed on zooplankton. Increased temperatures thus are expected to shorten development time of zooplankton, allowing for earlier and often greater reproductive effort. This shorten development time also affects adult body size as well as the size of offspring. Guinnee et al. (2004) found an inverse relationship between clutch size and egg volume. Smaller animals may result in lower overall biomass in the system and thus have effects on higher trophic levels.

\section{Temperature Effects on Mortality}

Mortality may also increase with increasing temperature, since lower temperatures down to some minimum favor longevity and survivorship (Moore et al. 1996). The increased rate of metabolic activity at higher temperatures has a cost that must be met through increased filtration, increased assimilation efficiency, or both. Should the costs of this increased metabolism be more than the energy amassed through 
increased feeding rate and assimilation efficiencies, then greater mortality would eventually occur. Increased temperatures may also result in physiological heat shock. Heat shock requires that heat shock proteins and other compounds be produced to compensate for the cellular biochemical damage (Kregel 2002). If enough heat shock proteins cannot be produced to overcome damage done, mortality would again be likely.

The current results show high mortality for both species at the highest and lowest temperatures tested. As mentioned earlier, at $10^{\circ} \mathrm{C}$ on low food quality no $D$. magna animals survived to produce a first clutch, while $D$. pulex animals on low food quality at $10^{\circ} \mathrm{C}$ also suffered high mortality rates $(90 \%)$. This indicates a strong effect of food quality on survivorship at low temperatures because mortality for both $D$. pulex and $D$. magna at $10^{\circ} \mathrm{C}$ was less (55\% and $62 \%$, respectively) when food quality was higher. High mortality was also observed for both species at the highest temperature tested $\left(30^{\circ} \mathrm{C}\right)$

\section{Conclusions}

The results of these experiments indicate possible strong interactions between food quality and temperature on both the growth and reproduction of $D$. pulex and $D$. magna. As our climate in North America continues to warm and nutrient inputs to freshwater systems are altered by human activity, it is important to understand how these key factors will interact to alter aquatic food webs. Species better adapted to higher temperatures may become more common in higher latitudes as native species become less common. Temperature may also alter how species respond to nutrient enrichment or limitation. The use of Daphnia in this series of experiments highlights the possible 
effects of these factors on key herbivores in freshwater systems. Future research should investigate the effects of a wide range of $\mathrm{C}: \mathrm{N}: \mathrm{P}$ ratios at a wider range of temperatures in order to better reflect natural conditions and understand how our changing climate will alter our lakes, rivers, and ponds in the future. Extreme weather events, which are predicted to increase, may result in alternating periods of floods and drought. Such conditions alter not only temperature but nutrient availability and will, therefore, have strong effects on aquatic systems. 
Table 8. Mortality rates for D. magna at $10,15,20$, and $25^{\circ}$ on either high quality or low quality food.

\begin{tabular}{|l|c|c|}
\cline { 2 - 3 } \multicolumn{1}{c|}{} & $\mathrm{n}$ & mortality \\
\hline 10 high & 13 & 0.38 \\
\hline 10 low & 8 & 1.0 \\
\hline 15 high & 18 & 0.11 \\
\hline 15 low & 10 & 0.2 \\
\hline 20 high & 15 & 0.13 \\
\hline 20 low & 10 & 0.5 \\
\hline 25 high & 13 & 0.23 \\
\hline 25 low & 12 & 0.8 \\
\hline
\end{tabular}

Table 9. Mortality rates for D. pulex at $10,15,20$, and $25^{\circ}$ on either high quality or low quality food.

\begin{tabular}{|l|c|c|}
\cline { 2 - 3 } \multicolumn{1}{c|}{} & $\mathrm{n}$ & mortality \\
\hline 10 high & 10 & 0.5 \\
\hline 10 low & 10 & 0.9 \\
\hline 15 high & 24 & 0.29 \\
\hline 15 low & 11 & 0.45 \\
\hline 20 high & 18 & 0.05 \\
\hline 20 low & 9 & 0.1 \\
\hline 25 high & 8 & 0.63 \\
\hline 25 low & 8 & 0.38 \\
\hline
\end{tabular}




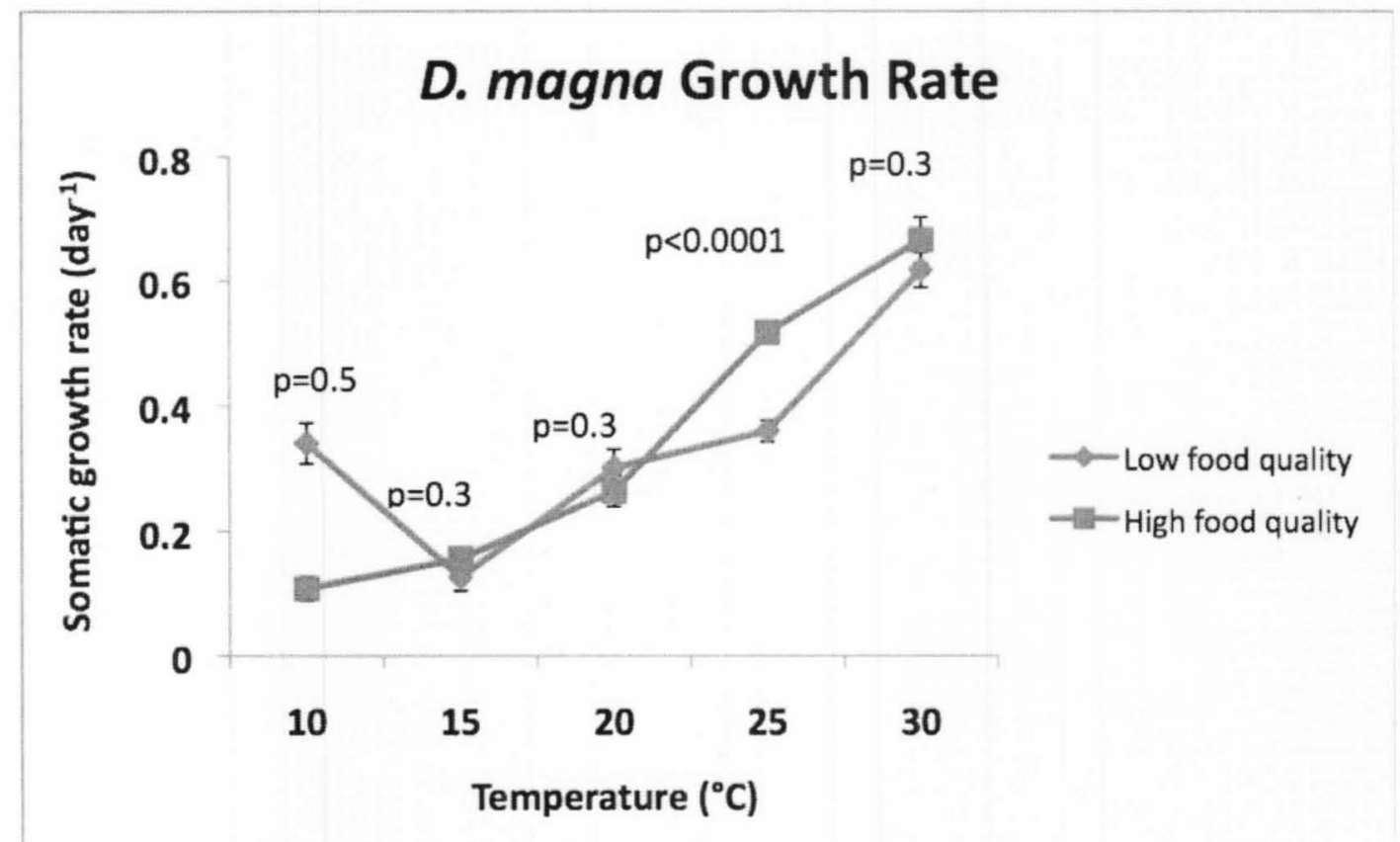

Figure 11. Growth rate ( $\pm 1 \mathrm{SE})$ for $D$. magna at high and low food qualities at 10, 15, 20,25 , and $30^{\circ} \mathrm{C}$.

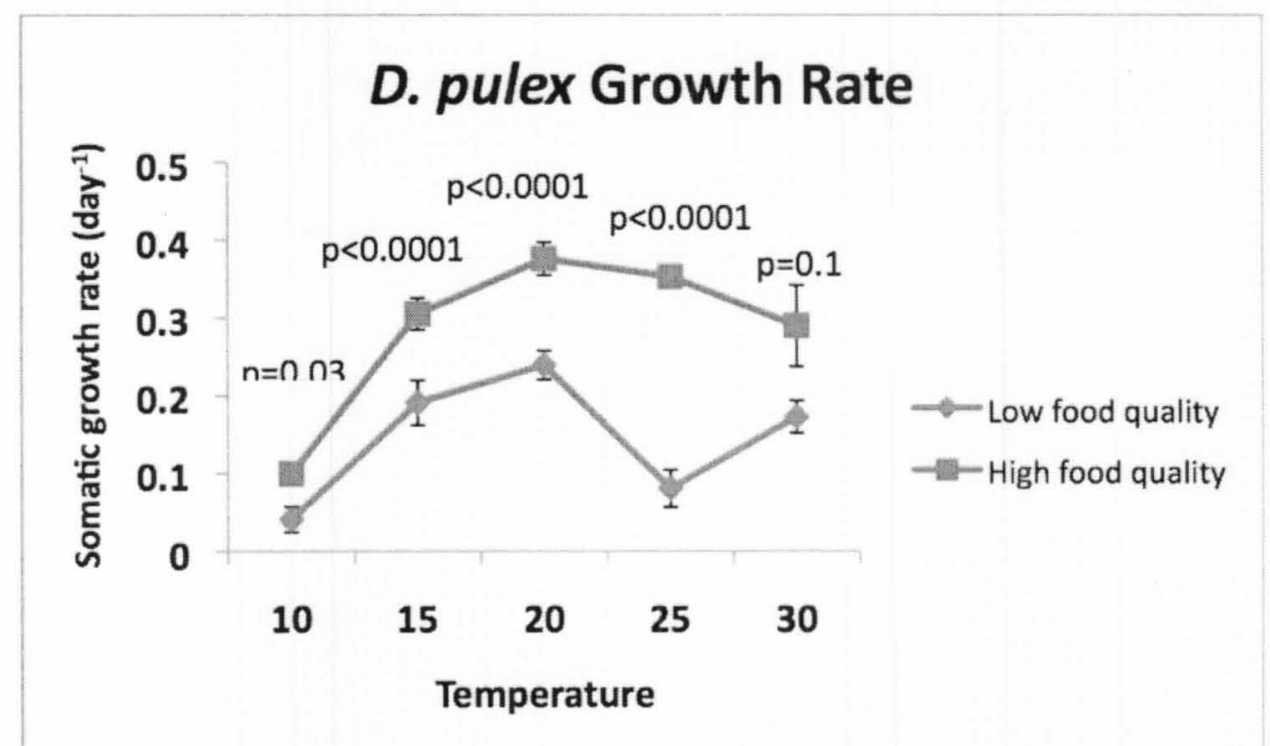

Figure 12. Growth rate ( $\pm 1 \mathrm{SE})$ for $D$. pulex at high and low food qualities at $10,15,20$, 25 , and $30^{\circ} \mathrm{C}$. 


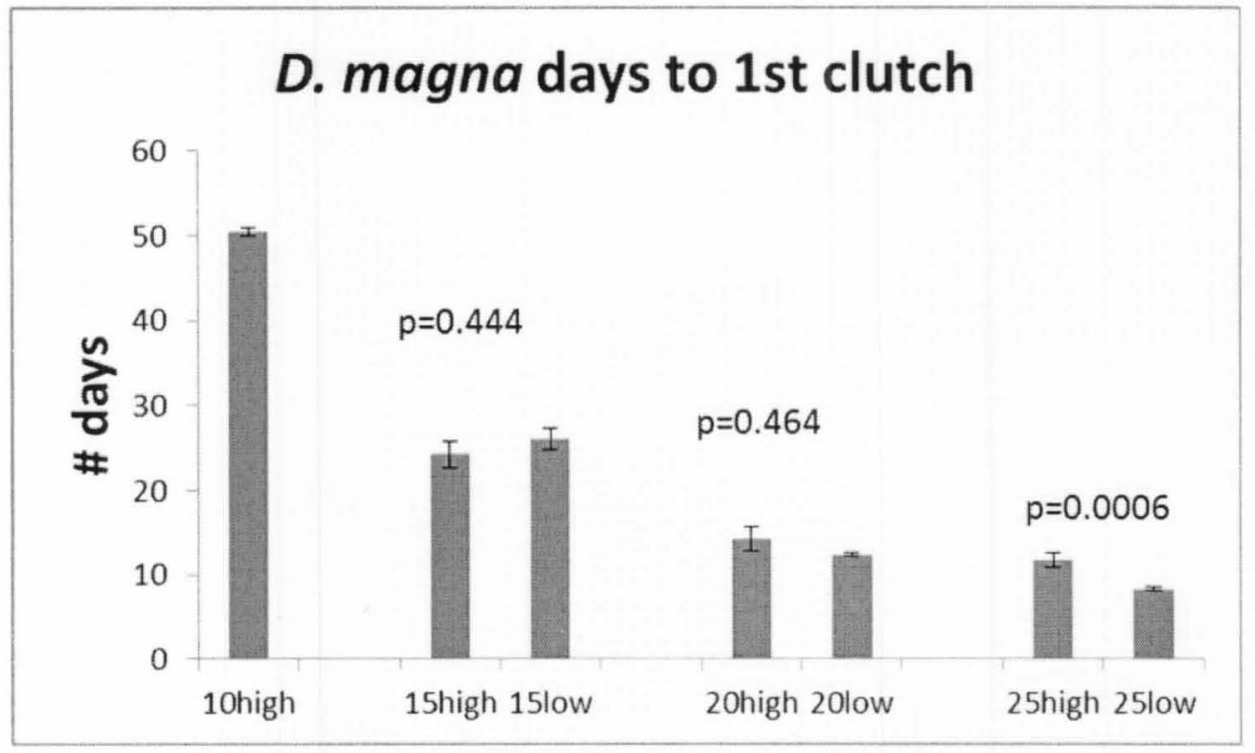

Figure 13. Days ( $\pm 1 \mathrm{SE}$ ) before production of the first clutch of offspring for D. magna.

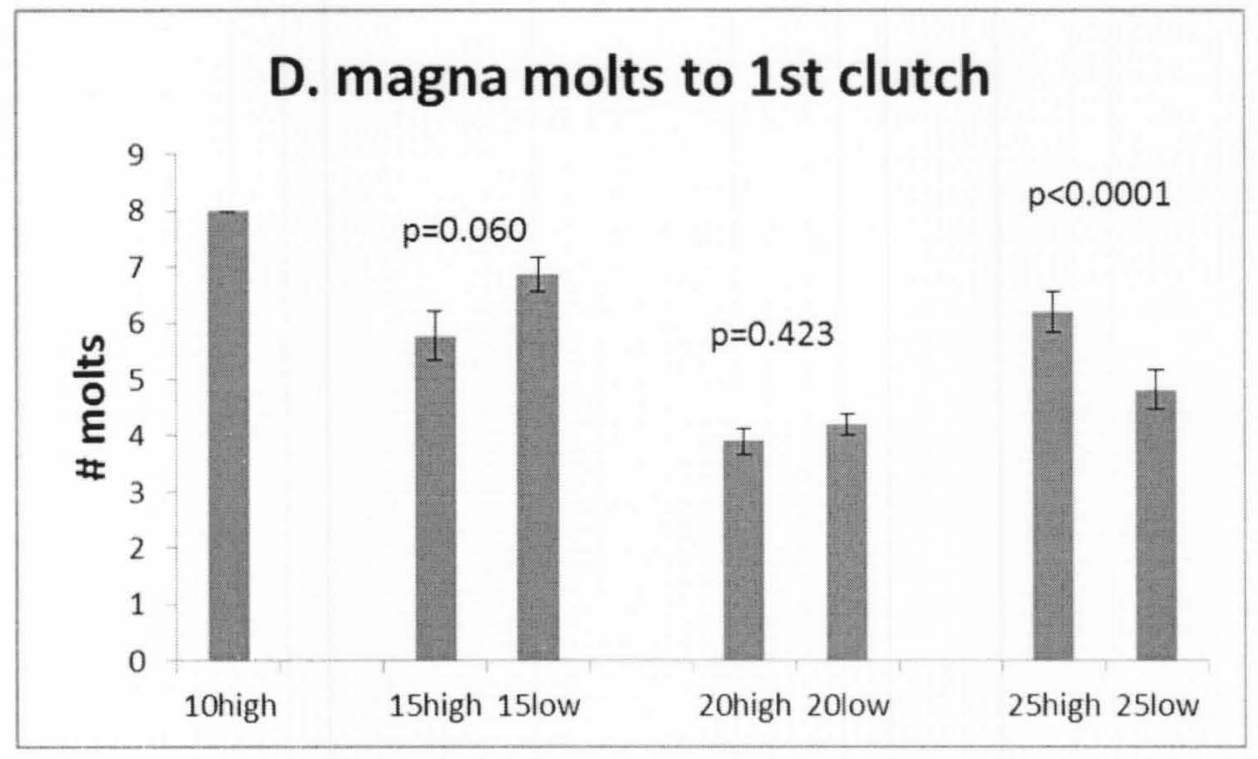

Figure 14. Number of molts ( $\pm 1 \mathrm{SE}$ ) before the first clutch of offspring for D. magna. 


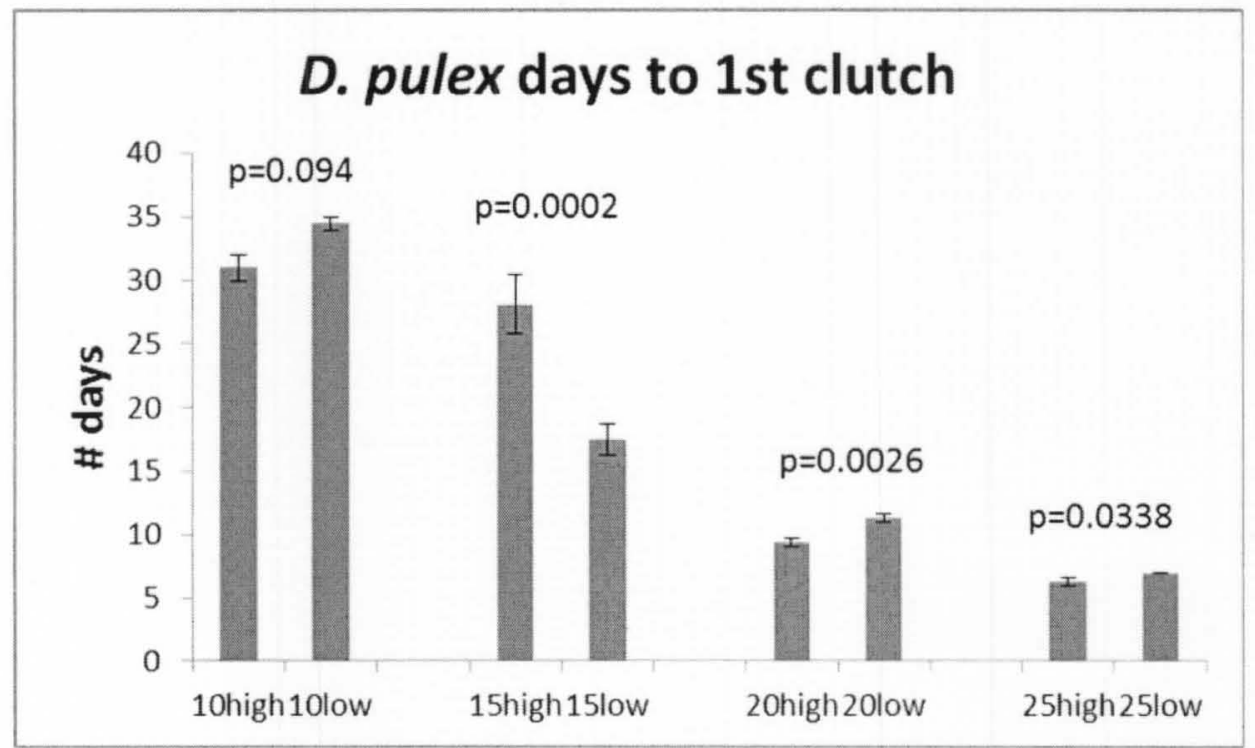

Figure 15. Days ( $\pm 1 \mathrm{SE}$ ) before production of the first clutch of offspring by $D$. pulex.

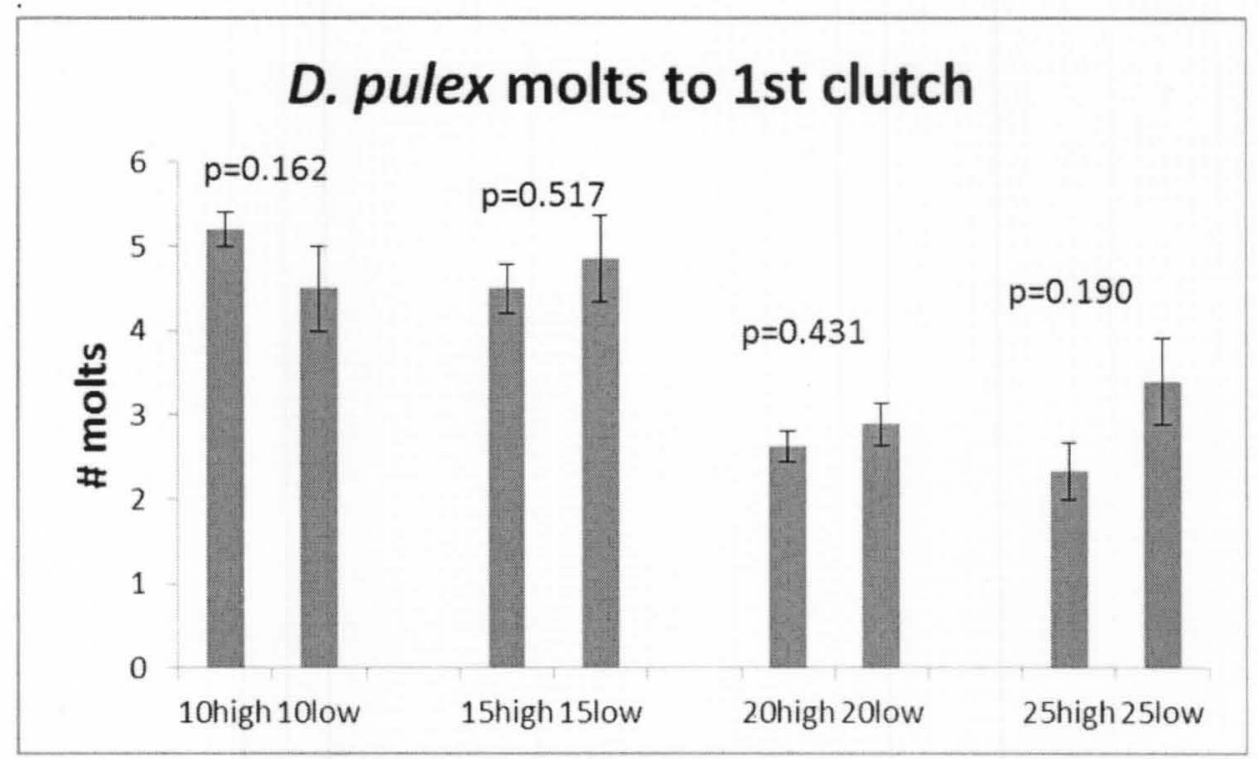

Figure 16. Number of molts $( \pm 1 \mathrm{SE}$ ) before production of the first clutch of offspring by D. pulex. 


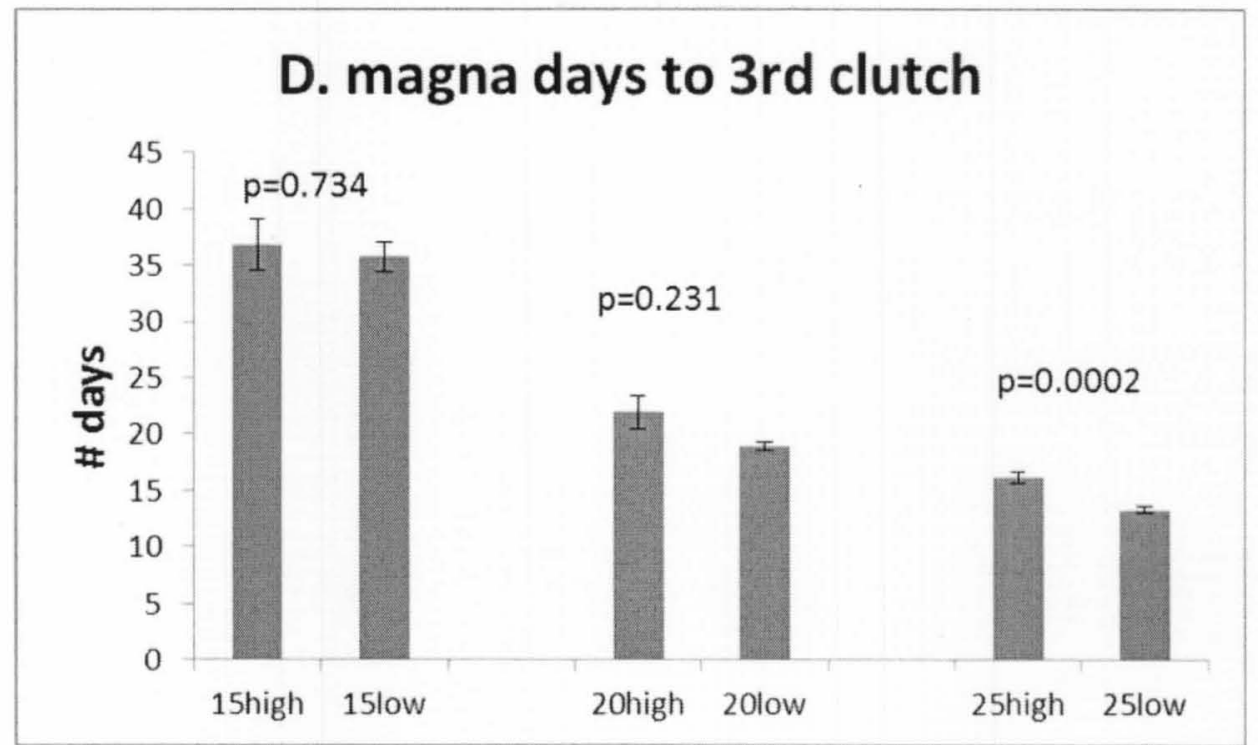

Figure 17. Days ( $\pm 1 \mathrm{SE}$ ) before production of the third clutch of offspring by D. magna.

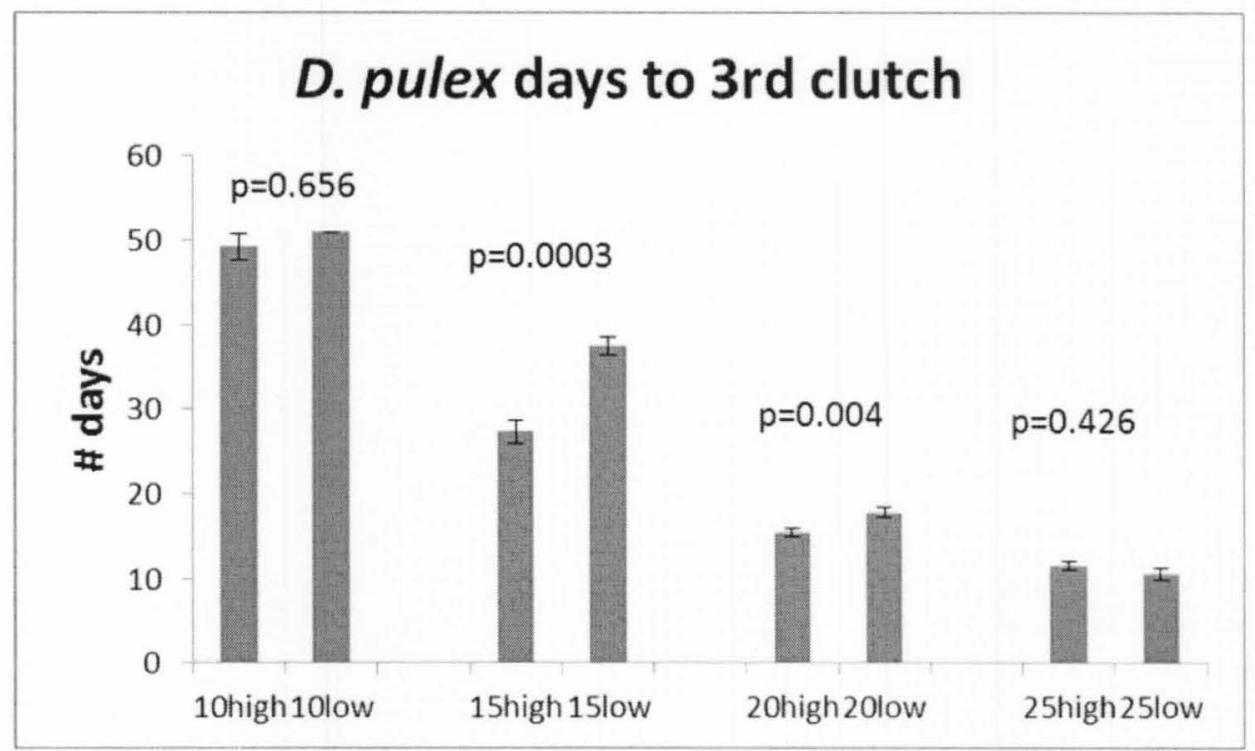

Figure 18. Number of days ( $\pm 1 \mathrm{SE}$ ) before production of the third clutch by $D$. pulex. 


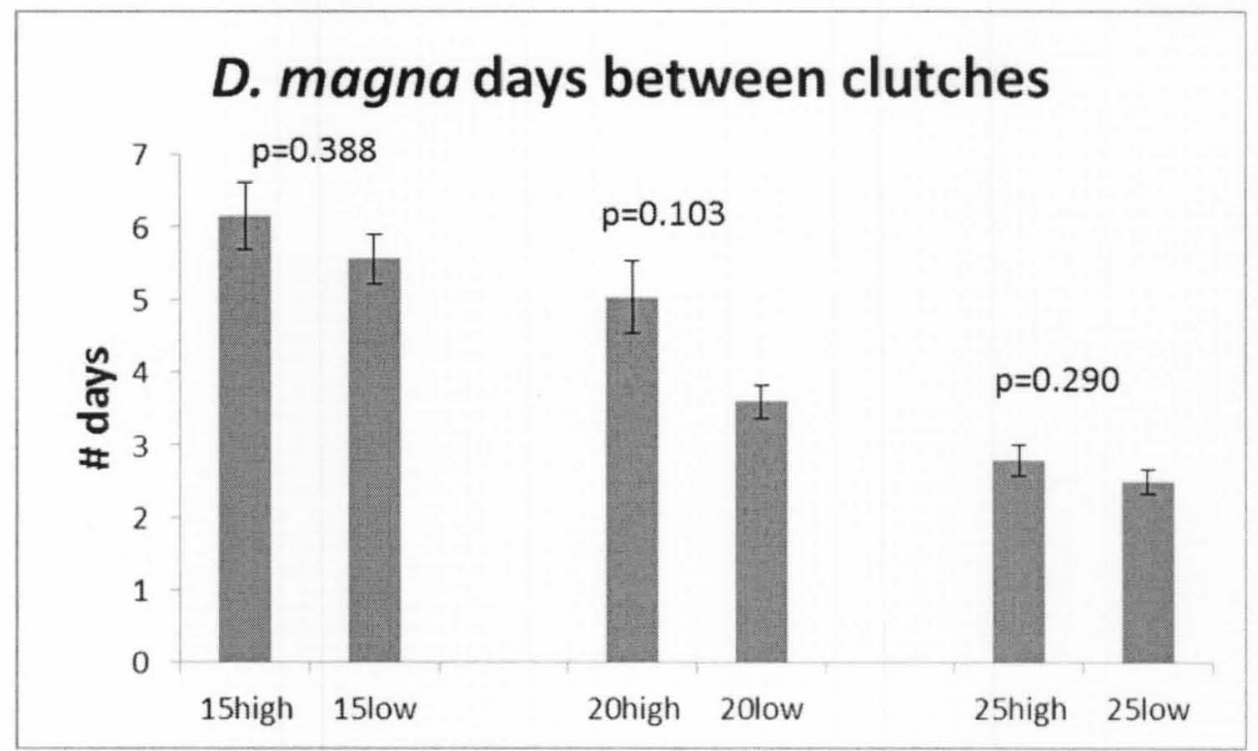

Figure 19. Days ( $\pm 1 \mathrm{SE}$ ) between clutches of offspring for D. magna.

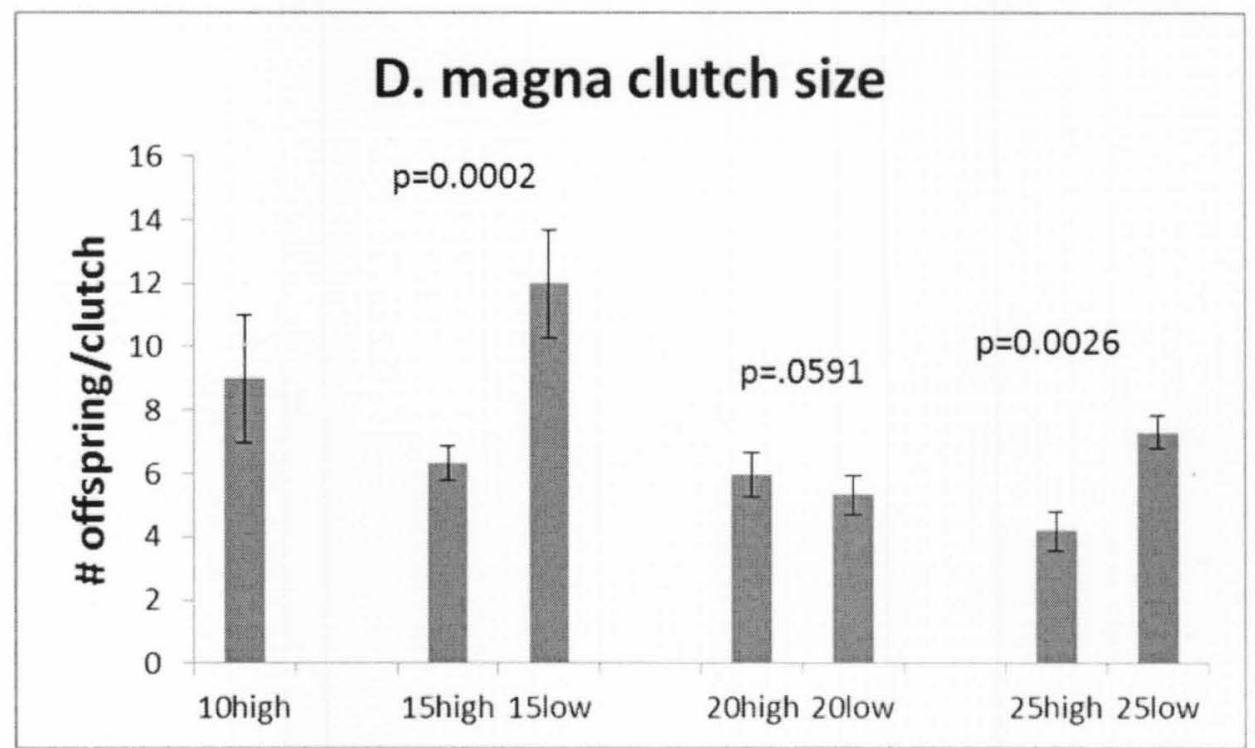

Figure 20. Average number of offspring ( $\pm 1 \mathrm{SE}$ ) per clutch for D. magna. 


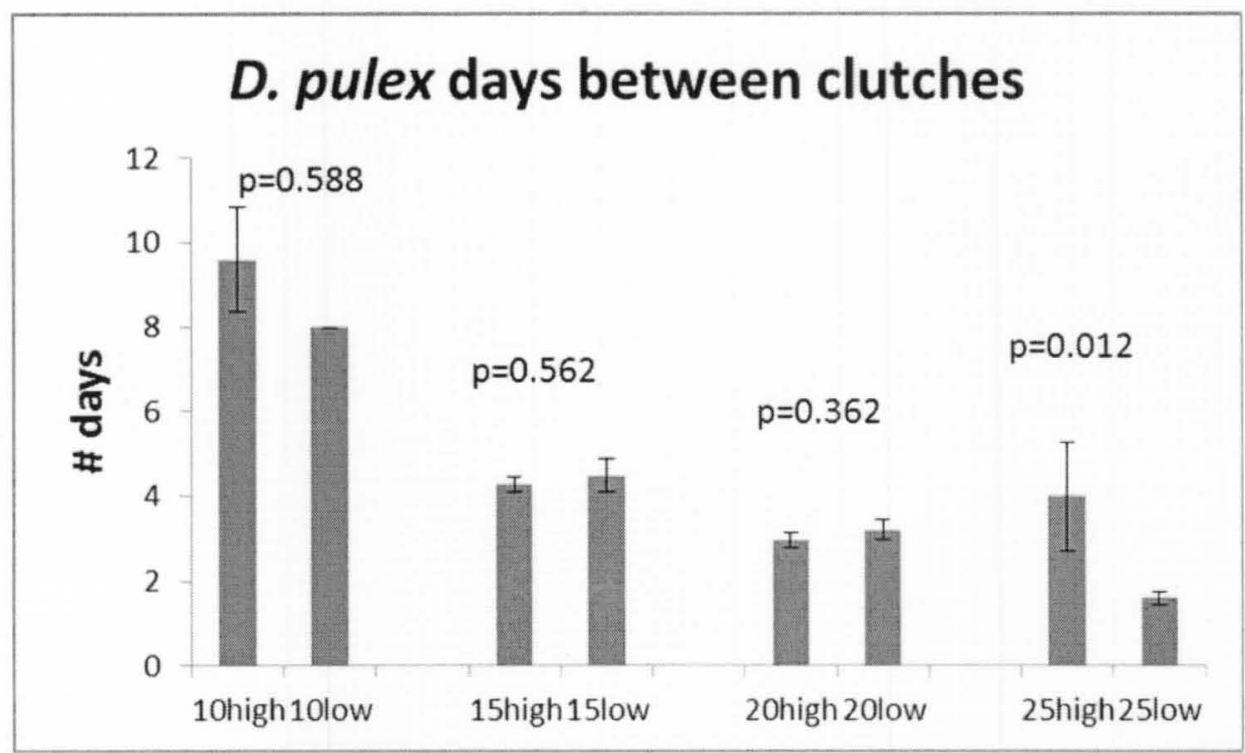

Figure 21. Average number of days ( $\pm 1 \mathrm{SE}$ ) between clutches of offspring for D. pulex.

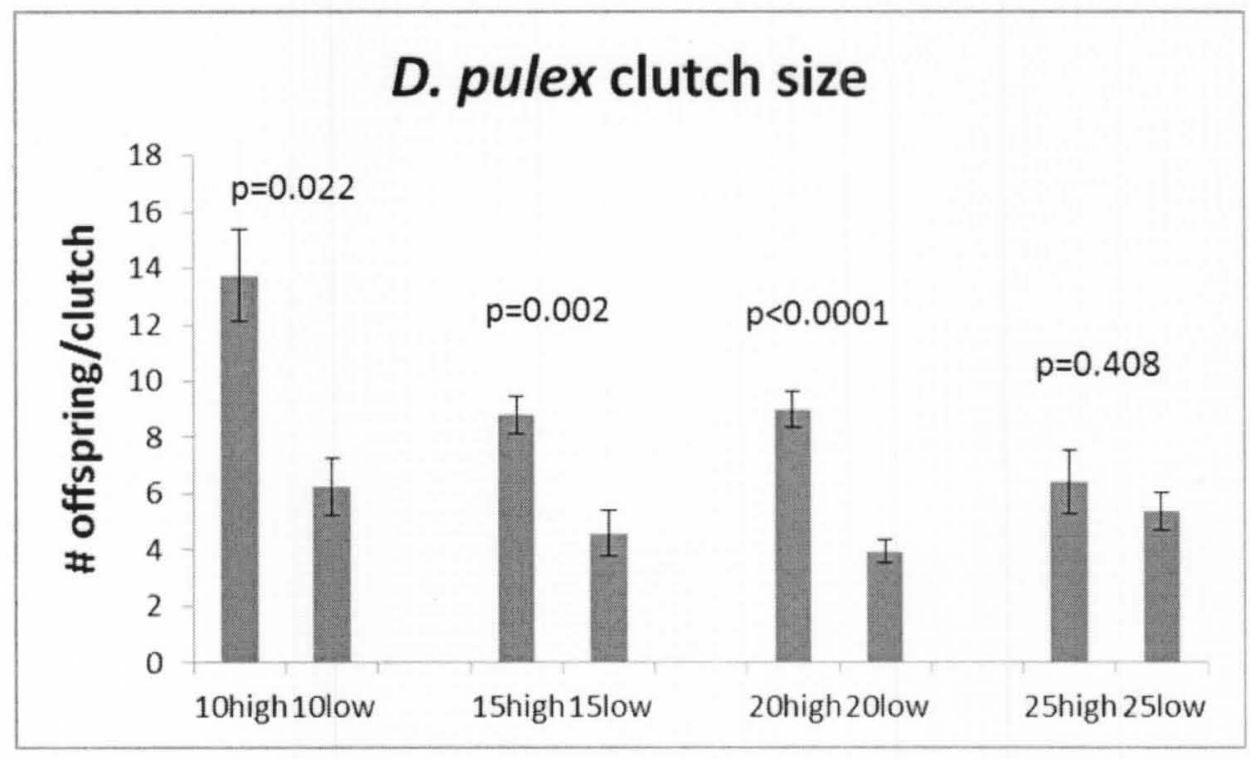

Figure 22. Average number of offspring ( $\pm 1 \mathrm{SE})$ per clutch for D. pulex. 


\section{CHAPTER 5: CONCLUSIONS}

Freshwaters, especially lakes, are strong indicators of the effects of climate change on their larger catchment areas. By capturing and sequestering terrestriallyderived carbon, integrating the physical, chemical and biological signals of the catchment, and cycling carbon, lakes can act as mitigators of climate change and can be "sentinels of change," demonstrating several mechanisms by which climate change will alter ecosystems (Williamson et al. 2009) such as alterations in rates of primary production and species ranges. As our freshwater ecosystems experience continued transformations as a result of global environmental change, it becomes increasingly important to understand how these ecosystems will respond to warmer temperatures, changing nutrient loads and exotic species introductions. To maintain ecosystem services from temperate freshwaters such as clean drinking water, flood mitigation, biodiversity maintenance, as well as providing a protein source for millions, managers of these systems must have reliable models upon which to base management decisions. The complex interactions of temperature and nutrient availability are difficult to predict, yet greater local and continental scale variation in these controllers of ecosystem processes and community composition are the future of temperate freshwaters. The research described here is intended to address how aquatic organisms may respond to increased temperatures and varying degrees of nutrient limitation or surplus in order to better 
understand how these factors will influence aquatic food webs. Among the main findings of my research is that nutrient limitation may play a greater role in regulating growth and reproduction of key zooplankton taxa at intermediate temperature ranges close to the temperature optima of these organisms. Higher temperatures may result in stronger heat stress that overrides any detectable responses to varying food quality, whether enriched or limited.

Increasing temperature and changes in precipitation will act together to alter the thermal regime of rivers, lakes, ponds, and streams because the thermal capacity and spatial distribution will depend partly on water volume and depth. Changes in temperature minima and maxima, the timing of freezing and ice breakup (in systems that will still experience ice cover), and thermal stratification will all effect freshwater organisms, from the bacteria that break down organic matter to the fish at the top of most aquatic food webs. While higher temperatures alone would favor higher rates of primary production, stronger thermal stratification that limits mixing may result in nutrient limitation in surface waters for longer periods within the year than those presently occurring; however, the extent of this limitation will also depend on temporal patterns of anthropogenic nutrient inputs that in turn vary with potentially altered magnitude and timing of precipitation events or snowmelt (Jankowski et al. 2006). Animals, too, would be expected to have a higher growth rate at increased temperatures within that animal's thermal tolerance, but temporal mismatch in productivity between consumers and their food resources may temper the effect of enhanced production. Should temperatures increase above an organism's temperature optimum, reduced growth rate, heat shock, and even death may occur, as seen with Daphnia's high mortality rate in Chapter 4. 
However, some animals such as Daphnia have the phenotypic plasticity and variation in the genetic egg bank to adapt to these conditions over time (Wojtal-Frankiewicz 2012). Thus Daphnia provide a reliable and pertinent model system with which to work for predicting global change effects on zooplankton populations and communities.

Global increases in bioavailable nitrogen are expected to continue this century (Gallaway et al. 1995). Increased inputs of nitrogen may be expected to increase the productivity of systems that have historically been nitrogen limited. However, increases in nitrogen availability may result in phosphorus limitation. Phosphorus limitation can particularly impact organisms with inherently high growth rates, since faster growth requires higher levels of phosphorus-rich ATP and RNA. This was observed in the growth rate study using Daphnia (Chapter 4) where growth rates of Daphnia were higher on phosphorus-rich food at higher temperatures and confirms the findings of Elser et al. (2010) who found decreased growth rates in zooplankton from lakes with high levels of nitrogen deposition. Such effects on Daphnia may well have cascading effects on overall food chain performance (Elser et al. 2010).

Freshwaters also face the threat of exotic species whose ability to persist in new environments, particularly those at high latitude and altitude, may be enhanced by increases in temperature and nitrogen availability. Opportunities for exotic species to be transported have increased as humans have made international transport more common (Mills et al. 1993). For example, the exotic cnidarian C. sowerbii has spread from its original habitat in China to every continent except Antarctica (Dumont 1994). 
The incidental introduction of exotic plant and animal species can result in changes to the diversity of ecosystems, as evidenced in Chapters 2 and 3 where $C$.

sowerbii was shown to kill a wide range of zooplankton, whether they were consumed or not. This resulted in a reduction in the Shannon Diversity Index for zooplankton when medusae were present. In addition, there was a significant reduction in total zooplankton abundance when medusae were present after only 2 days. All species present except for Keratella sp. were impacted by the presence of $C$. sowerbii. Blooms of $C$. sowerbii are associated with warm late summer temperatures and so blooms may increase in occurrence and duration as aquatic waters continue to warm in the coming decades. Should such blooms occur earlier and last longer, the effects on zooplankton communities could be stronger.

These changes in the zooplankton community can greatly alter both the standing stock of phytoplankton, food web structure and the availability of food for higher trophic levels. In addition, animals once experiencing predation pressure may become more abundant once that predator is removed. In Chapter 3, the reduction of one of Keratella's predators (adult Copepods) in the presence of high density medusae was correlated with a large increase in Keratella sp. Such indirect effects on the abundance of some zooplankton taxa may well impact other prey species. As the introduction of exotic species continues and even increases, it will be more important than ever to understand how the interaction of these factors - temperature, nutrients, and exotics-will affect our freshwater systems. 
I sought in Chapter 4 to highlight the complex interactions of temperature and nutrient availability on the growth rate and reproductive traits of an important and ubiquitous genus, Daphnia. Daphnia's ability to serve as a predictive model for how freshwater ecosystems will be altered make research with this genus increasingly important as we strive to understand the changes taking place in freshwaters. Their ability to adapt to a changing environment allows us to mimic these changes in the lab and better understand the complex responses of organisms to their environment. Use of such lab experiments have been found to be fully justified when constraints in natural systems are too strong (Cauchi et al. 2000). The results herein demonstrate that there are strong interactions between food quality and temperature for the growth and reproduction of Daphnia species. Their differential responses to food quality at different temperatures indicate the need for further research in order to understand these interactions more fully. For example, while some measures of fecundity (days to first clutch, days to third clutch and days between clutches) showed the predicted inverse relationship to increasing temperature, others measures, such as the number of molts before first reproduction, decreased at higher temperatures despite increased growth rates. This can impact factors such as adult body size, which in turn may alter the predation risk for Daphnia. Thus, growth rate and fecundity have strong implications for Daphnia's fitness and ability to thrive in complex aquatic ecosystems.

The future of freshwater systems is certainly important to human health and wellbeing. Humans depend on freshwater ecosystems to provide clean drinking water, food, flood mitigation, and other ecosystem services. I hope that my contribution to this field will lead to further research and the development of useful models for understanding how 
freshwaters are changing as climate change and human impacts continue to increase in the decades ahead. 


\section{REFERENCES}

Acharya, K., Kyle, M. \& Elser, J. J. (2004) Biological stoichiometry of Daphnia growth: An ecophysiological test of the growth rate hypothesis. Limnology and Oceanography 49: 656-665.

Acharya, K., Jack, J. \& Smith, A.S. (2006) Stoichiometry of Daphnia lumholtzi and their invasion success: are they linked? Archiv für Hydrobiologie 165: 433-453.

Acharya, K., Bukaveckas, P.A., Jack, J.D., Kyle, M., and Elser, J.J. (2006) Consumer growth linked to diet and RNA-P stoichiomentry: Response of Bosmina to variation in riverine food resources. Limnology and Oceanography. 5(4):1859-1869.

Acker, T.S. (1976) Craspedacusta sowerbyi: an analysis of an introduced species. In: Mackie, G.O. (Ed.), Coelenterate Ecology and Behavior. Plenum Press, New York: 219226.

Adema, D.M.M. (1978) Daphnia magna as a test animal in acute and chronic toxicity tests. Hydrobiologia. 59(2):125-134.

Adrian, R., Wilhelm, S., and Gerten, D. (2006) Life-history traits of lake plankton species may govern their phonological response to climate warming. Global Change Biology. $12: 652-661$.

Albouy, C., Guilhaumon, F., Araújo, M.B., Mouillot, D., and Leprieur, F. (2012) Combining projected change in species richness and composition reveals climate change impacts on coastal Mediterranean fish assemblages. Global Change Biology. 18:29953003.

Arendt, J.D. (1997). Adaptive intrinsic growth rates: an integration across taxa. The Quarterly Review of Biology 72: 149-198.

Arnold, D.E. (1971) Ingestion, assimilation, survival and reproduction by Daphnia pulex fed seven species of blue-green algae. Limnology and Oceanography. 16(6): 906-920.

Boothroyd, I.K.G., Etheredge, M.K., and Green, J.D. (2002) Spatial distribution, size structure, and prey of Craspedacusta sowerbii in a shallow New Zealand lake. Hydrobiologia. 468, 23-32. 
Brett, M.T. and Müller-Navarra, D.C. (1997) The role of highly unsaturated fatty acids in aquatic foodweb processes. Freshwater Biology. 38:483-499.

Brooks, J.L. and Dodson, S.I. (1965) Predation, body size and composition of the plankton. Science. 150:28-35.

Carpenter, S.R., and J.F. Kitchell (1984) Plankton community structure and limnetic primary production. American Naturalist. 124:159-172.

Cauchie, H.M., Thys, I., Hoffman, L. and Thomé, J.P. (2000) In situ laboratory estimations of length-weight regression and growth rate of Daphnia magna (Branchiopoda, Amonopoda) from an aerated waste stabilization pond. Hydrobiologia. 421:47-59.

Chen, C.Y. and Folt, C.L. (1996) Consequences of fall warming for zooplankton overwintering success. Limnology and Oceanography. 41(5):1077-1086.

Colbourne, J.K., Singan, V.R., and Gilbert, D.G. (2005) wFleaBase: the Daphnia Genome Database. BMC Bioinformatics. 6:45.

Colbourne, J.K., Pfrender, M.E., Gilbert, D., Thomas, W.K., Tucker, A., Oakley, T.H., Tokishita, S. et al. (2011) The ecoresponsive genome of Daphnia pulex. Science. 331:555-561.

Cole, P.C, Luecke, C., Wurtsbaugh, W.A., and Burkart, G. (2002) Growth and survival of Daphnia in epilimnetic and metalimnetic water from oligotrophic lakes: the effects of food and temperature. Freshwater Biology. 47(2113-2122).

Craddock, D.R. (1976) Effects of increased water temperature on Daphnia pulex. Fishery Bulletin. 74(2):403-408.

Crease, T. J. and Lynch, M. (1991) Ribosomal DNA variation in Daphnia pulex. Molecular Biology and Evolution. 8(5): 620-640.

Davis, C.C. (1955) Notes on the food of Craspedacusta sowerbii in Crystal Lake, Ravenna, Ohio. Ecology. 36:364--366.

Dendy, J.S. (1978) Polyps of Craspedacusta sowerbyi as predators on young striped bass. Fish Culturist. 40(1): 5-6.

Dodson, S. I and Cooper S. D. (1983) Trophic relationships of the freshwater jellyfish Craspedacusta sowerbyi Lankester 1880. Limnology and Oceanography. 28, 345-351.

Dukes, J.S. and Mooney, H.A. (2004) Disruption of ecosystem processes in western North America by invasive species. Revista chilena de historia natural. 77(3):411-237. 
Dumont, H.J. (1994) The distribution and ecology of the fresh- and brackish-water medusae of the world. Hydrobiologia. 272:1-12.

Easterling, D.R., Horton, B., Jones, P.D., Peterson, T.C., Karl, T.R., Parker, D.E., Salinger, M.J., Razuvayev, V., Plummer, N., Jamason, P., and Folland, C.K. (1997) Maximum and minimum temperature trends for the globe. Science. 227:264-367.

Eaton, A.D., Clesceri, L.S. and Greenberg, A.E. (1995) Standard Methods for the Examination of Water and Wastewater. American Public Health Association. Washington, D.C.

Ebert, D., Zschokke-Rohringer, C.D., and Carius, H.J. (1998) Within- and betweenpopulation variation for resistance of Daphnia magna to the bacterial endoparasite pasteuria ramose. Proceedings of the Royal Society. 265:2127-2134.

Edmondson, W.T. (1959) Freshwater Biology, $2^{\text {nd }}$ Edition. John Wiley and Sons, New York.

Elser, J.J., H. Hayakawa, \& J. Urabe (2001). Nutrient limitation reduces food quality for zooplankton: Daphnia response to seston phosphorus enrichment. Ecology. 82: 898903.

Elser, J.J., O'Brien, W.J., Dobberfuhl, D.R., and Dowling, T.E. (2000) The evolution of ecosystem processes: growth rate and elemental stoichiometry of a key herbivore in temperate and arctic habitats. Journal of Evolutionary Biology. 13:845-853.

Elser, J.J., Bracken, M.E.S., Cleland, E.E., Gruner, D.S., Harpole, W.S., Hillebrand, H., Ngai, J.T., Seabloom, E.W., Shurin, J.B., and Smith, J.E. (2007) Global analysis of nitrogen and phosphorus limitation of primary producers in freshwater, marine, and terrestrial ecosystems. Ecology Letters. 10:1135-1142.

Elser, J.J., Kyle, M., Steger, L., Nydick, K.R., and Baron, J.S. (2009) Nutrient availability and phytoplankton nutrient limitation across a gradient of atmospheric nitrogen deposition. Ecology. 90(11):3062-3073.

Elser, J.J., Peace, A.L., Kyle, M., Wojewodzic, M., McCrackin, M.L., Andersen, T., and Hessen, D.O. (2010) Atmospheric nitrogen deposition is associated with elevated phosphorus limitation of lake zooplankton. Ecology Letters. 13:1256-1261.

Fey, S. B., and Cottingham, K.L. (2011) Linking biotic interactions and climate change to the success of exotic Daphnia lumholtzi. Freshwater Biology. 56:2196-2209.

Ficetola, G.F., Siesa, M.E., De Barnardi, F., and Padoa-Schioppa, E. (2012) Complex impact of an invasive crayfish on freshwater foodwebs. Biodiversity and Conservation. 21:2641-2651.

Gallaway, J.N., Schlesinger, W.H., Levy II, H., Michaels, A., and Schnoor, J.L. (1995) Nitrogen fixation: atmospheric enhancement-environmental response. Global Biogeochemical Cycles. 9:235-252. 
Galloway, J.N., Townsend, A.R., Erisman, J.W., Bekunda, M., Cai, Z., Freney, J.R., Martinelli, L.A., Seitzinger, S.P., and Sutton, M.A. (2008) Transformation of the nitrogen cycle: recent trends, questions, and potential solutions. Science. 320:889-892.

Gerke, P., Börding, C., Zeis, B., and Paul, R.J. (2011) Adaptive haemoglobin gene control in Daphnia pulex at different oxygen and temperature conditions. Comparative Biochemistry and Physiology. 159:56-65.

Gilbert, J.J. and Stemberger, R.S. (1984) Spine Development in the rotifer Keratellacochlearis - induction by cyclopoid copepods and Asplanchna. Freshwater Biology. 14(6):639-647.

Gladyshev, M.I., Arts, M.T., Sushchik, N.N. (2009) Preliminary estimates of the export of omega-3 highly unsaturated fatty acids (EPA + DHA) from aquatic to terrestrial ecosystems. In: Arts, M.T., Kainz, M., Brett, M.T. (Eds.), Lipids in Aquatic Ecosystems. Springer, New York, pp. 179-209.

Goss, L.B. And Bunting, D.L. (1983) Daphnia development and reproduction responses to temperature. Journal of Thermal Biology. 4:375-380.

Govers, H., Ruepert, C., and Aiking, H. (1984) Quantitative structure-activity relationships for polycyclic aromatic hydrocarbons: Correlation between molecular connectivity, physico-chemical properties, bioconcentration and toxicity in Daphnia pulex. Chemosphere. 13(2):227-236.

Guinnee, M., West, S., and Little, T.J. (2004) Testing small clutch size models with Daphnia. American Naturalist. 163:880-887.

Gulati, R.D. and DeMott, B. (1997) The Role of Food Quality for Zooplankton. Freshwater Biology. 38:445.

Gyllström, M., Hansson, L.A., Jeppesen, E., García-Criado, F., Gross, E., Irvine, K., Kairesalo, T.,Kornijów, R., Miracle, M.R., Nykänen, M., Nõges, T., Romo, S., Stephen, D., Van Donk, E., and Moss, B. (2005) The role of climate in shaping zooplankton communities of shallow lakes. Limnology and Oceanography. 50:2008-2021.

Hall, E.K., Neuhauser, C., and Cotner, J.B. (2008) Toward a mechanistic understanding of how natural bacterial communities respond to changes in temperature in aquatic ecosystems. The ISME Journal. 2:471-481.

Haney, J.F. and Hall, D.J. (1972) Sugar-coated Daphnia: A preservation technique for Cladocera. Limnology and Oceanography. 18(2):331-333.

Harrel, R.C. (2002) New distribution record and ecological notes of the freshwater hydrozoan Craspedacusta sowerbii in Southeast Texas. Texas Journal of Science. 54(4):357-362. 
Heijerick, D.G., Schamphelaere, K.A.C., and Janssen, C.R. (2002) Predicting acute zinc toxicity for Daphnia magna as a function of key water chemistry characteristics:

Development and validation of a biotic ligand model. Environmental Toxicology and Chemistry. 21(6): 1309-1315.

Holzapfel, A.M., and Vinebrooke, R.D. (2005) Environmental warming increases invasion potential of alpine lake communities by imported species. Global Change Biology. 11:2009-2015.

Houghton, J.T., Jenkins, G.J., and Ephraums, J.J. eds. (1990) Report prepared for Intergovernmental Panel on Climate by Working Group I. Cambridge University Press, Cambridge, Great Britian, New York, NY,USA and Melbourne, Australia.

Ilarri, M.I., Freitas, F., Costa-Dias, S., Antunes, C., Guilhermino, L., and Sousa, R. (2012) Associated macrozoobenthos with the invasive Asian clam Corbicula fluminea. Journal of Sea Research. 72:113-120.

Jankowski, T. (2000) Chemical composition and biomass parameters of a population of Craspedacusta sowerbii Lank1880 (Cnidaria: Limnomedusa). Journal of Plankton Research. 22:1329-1340.

Jankowski, T. and Ratte, H.T. (2000) On the influence of the freshwater jellyfish Craspedacusta sowerbii on the zooplankton community. Verhandlungen des Internationalen Verien Limnologie. 27:1-4.

Jankowski, T. (2001) The freshwater medusae of the world - a taxonomic and systematic literature study with some remarks on other inland water jellyfish. Hydrobiologia. 462: 91-113.

Jankowski, T. (2004) Predation of freshwater jellyfish on Bosmina: the consequences for population dynamics, body size, and morphology. Hydrobiologia, 530/531:521-528.

Jankowski, T., Strauss, T., and Ratte, H.T. (2005) Trophic interactions of the freshwater jellyfish Craspedacusta sowerbii. Journal of Plankton Research. 27:811-823.

Jankowski, T., Livingstone, D.M., Bührer, H., Forster, R., Niederhauser, P. (2006) Consequences of the 2003 European heat wave for lake temperature profiles, thermal stability, and hypolimnetic oxygen depletion: Implications for a warmer world. Limnology and Oceanography. 51(2):815-819.

Jeschke, J.M. and Strayer, D.L. (2005) Invasion success of vertebrates in Europe and North America. Proceedings of the National Academies of Science. 102(20):7198-7202.

Karl, T.R., Melillo, J.M., and Peterson, T.C. (2009) Global Climate Change Impacts in the United States. Cambridge University Press. 
Kopáĉek, J., Procházková, L., Stuchlik, E., and Blažka, P. (1995) The nitrogenphosphorus relationship in mountain lakes: Influence of atmospheric input, watershed, and pH. Limnology and Oceanography. 40(5):930-937.

Kregel, K.C. (2002) Invited Review: Heat shock proteins: modifying factors in physiological stress response and acquired thermotolerance. Journal of Applied Physiology. 92:2177-2186.

Kundzewicz, Z.W., L.J. Mata, N.W. Arnell, P. Döll, P. Kabat, B. Jiménez, K.A. Miller, T. Oki, Z. Sen and I.A. Shiklomanov, 2007: Freshwater resources and their management. Climate Change 2007: Impacts, Adaptation and Vulnerability. Contribution of Working Group II to theFourth Assessment Report of the Intergovernmental Panel on Climate Change, M.L. Parry, O.F. Canziani, J.P. Palutikof, P.J. van der Linden and C.E. Hanson, Eds., Cambridge University Press, Cambridge, UK, 173-210.

Lagerspetz, K.Y. and Vanio, L.A. (2006) Thermal behavior of crustaceans. Biology Review of the Cambridge Philosophical Society. 81:537-58.

Lampert, W. \& Trubetskova, I. (1996) Juvenile growth rate as a measure of fitness in Daphnia. Functional Ecology. 10:631-635.

Lampert, W. (2006) Daphnia: Model herbivore, predator and prey. Polish Journal of Ecology. 54(4): 607-620.

Lampert, W. and Sommer, U. (2007) Limnoecology: The Ecology of Lakes and Streams. Oxford University Press. Oxford, England.

Laudon, H., Buttle, J., Carey, S.K., McDonnell, J., McGuire, K., Seibert, J., Shanley, J., Soulsby, C., and Tetzlaff, D. (2012) Cross-regional prediction of long-term trajectory of stream water DOC response to climate change. Geophysical Research Letters. 39:1-6.

LeBlanc, G.A. (1980) Acute toxicity of priority pollutants to water flea (Daphnia magna). Bulletin of Environmental Contamination and Toxicology. 24:684-691.

Lei, C. and Armitage, K.B. (1980) Growth, development and body size of field and laboratory populations of Daphnia ambigua. Oikos. 35:31-48.

Livingstone, D.M., Adrian, R., Blenckner, T., George, G., and Weyhenmeyer, G.A. (2010) Lake Ice Phenology in The Impact of Climate Change on European Lakes, eds. D.G. George. Springer Aquatic Ecology Series.

Lodge, D.M. (1993) Biological Invasions: Lessons for Ecology. TREE 8(4):133-137. 
Lynch, M. (1989) Complex interactions between natural coexploiters-Daphnia and Ceriodaphnia. Ecology. 59(3):552-564.

MacIsaac, H.J., Hebert, P.D.N., and Schwartz, S.S. (1985) Inter and intraspecific variation in acute thermal tolerance of Daphnia. Physiology and Zoology. 58:350-355.

Malin, M.A. and Parton, W.E. (1989) Thermal tolerances of common cladocera. Journal of Freshwater Ecology. 5:45-51.

Magnuson, J.J., Robertson, D.M., Benson, B.J., Wynne, R.H., Livingstone, D.M., Arai, T., Assel, R.A., Barry, R.G. Card, V., Kuusisto, E., Granin, N.G., Prowse, T.D., Stewart, K. M., and Vuglinski, V.S. (2000) Historical trends in lake and river ice cover in the northern hemisphere. Science. 289:1743-1745.

Martin, L.E. (2001) Limitations on the use of impermeable mesocosms for ecological experiments involving Aurelia sp. (Scyphozoa: Semacostomeae). Journal of Plankton Research. 23:1-10.

Martinez-Jeronimo, F. (2012) Description of the individual growth of Daphnia magna (Crustacea: Cladocerae) through the von Bertanlanffy growth equation. Effect of photoperiod and temperature. Limnology. 13:65-71.

Masclaux, H., Bec, A., Kainz, M.J., Perriere, F., Desvilettes, C., and Bourdier, G. (2012) Accumulation of polyunsaturated fatty acids by cladocerans: effects of taxonomy, temperature, and food. Freshwater Biology. 57:696-703.

Mataskis, S. and Conover, R.J. (1991) Abundance and feeding of medusae and their potential impact as predators on other zooplankton in Bedford Basin (Nova Scotia, Canada) during spring. Canadian Journal of Fisheries and Aquatic Science. 48:14191430.

McCauley, E., Murdoch, W.W., Nisbet, R.M., and Gurney, W.S.C. (1990) The physiological ecology of Daphnia: development of a model of growth and reproduction. Ecology. 71:703-715.

McFeeters, B.J. and Frost, P.C. (2011) Temperature and the effects of elemental food quality on Daphnia. Freshwater Biology. 56:1447-1455.

Meehl, G.A. and Tebaldi, C. (2004) More Intense, More Frequent, and Longer Lasting Heat Waves in the $21^{\text {st }}$ Century. Science. 305:994-997.

Mills, E.L., Leach, J.H., Carlton, J.T., and Secor, C.L. (1993) Exotic species in the Great Lakes: A history of biotic crises and anthropogenic introductions. Journal of Great Lakes Research. 19:1-54.

Mills, C.E. (2001) Jellyfish blooms: are populations increasing globally in response to 
changing ocean conditions? Hydrobiologia. 451:55-68.

Mitchell, S.E. and Lampert, W. (2000) Temperature adaptation in a geographically widespread zooplankter, Daphnia magna. Journal of Evolutionary Biology. 13:371-382.

Moore, M.V., Folt, C.L., and Stemberger, R.S. (1996) Consequences of elevated temperatures for zooplankton assemblages in temperate lakes. Archiv for Hydrobiologia. 135(3):289-319.

Morin, P.J. (1999) Community Ecology. Blackwell Publishing, Oxford, UK.

Mulder, K. and Bowden, W.B. (2007) Organismal stoichiometry and the adaptive advantage of variable nutrient use and production efficiency in Daphnia. Ecological Modelling. 202:427-440.

O'Connor, M.I., Piehler, M.F., Leech, D.M., Anton, A., Bruno, J.F. (2009) Warming and resource availability shift food web structure and metabolism. PLoS Biology. 7(8):1-6.

Orcutt, J.D. and Porter, K.G. (1983) Diel vertical migration by zooplankton: Constant and fluctuating temperature effects on life history parameters of Daphnia. Limnology and Oceanography. 28(4):720-730.

Pajk, F., von Elert, E., and Fink, P. (2012) Interactions of changes in food quality and temperature reveals maternal effects on fitness parameters of a keystone aquatic herbivore. Limnology and Oceanography. 57(1):281-292.

Pangle, K.L. and Peacor, S.D. (2010) Temperature gradients, not food resource gradients, affect growth rate of migrating Daphnia mendotae in Lake Michigan. Journal of Great Lakes Research. 36:345-350.

Paul, M.J. and Meyer, J.L. (2001) Streams in the urban landscape. Annual Review of Ecology, Evolution and Systematics. 32:333-365.

Paul, R.J., Lamkemeyer, T., Maurer, J., Pinkhouse, O., Pirow, R., Weidl, M., and Zeis, B. (2004) Thermal acclimation in the microcrustecean Daphnia: a survey of behavioral, physiological and biochemical mechanisms. Journal of Thermal Biology. 29:655-662.

Pejchar, L. and Mooney, H.A. (2009) Invasive species, ecosystem services and human well-being. Trends in Ecology and Evolution. 24(9):497-504.

Pennak, R.W. (1989) Coelenterata (Hydroids, Jellyfish). Freshwater Invertebrates of the United States, 3rd Edition. John Wiley \& Sons, New York.

Pérez-Bote, J.L., Muñoz, A., Morán, R., Roso, R., and Romero, A.J. (2006) First record of Craspedacusta sowerbyi Lakester, 1880 (Cnidaria: Limnomedusae: Olindiidae) in the Proserpina Reservoir (Extremadura, SW Spain) with notes on their feeding habits. 
Belgian Journal of Zoology 136:163-166.

Persson, J., Wojewodzic, M.W., Hessen, D.O., and Andersen, T. (2011) Increased risk of phosphorus limitation at higher temperatures for Daphnia magna. Oecologia. 165:123129.

Pitt, K.A., Welsh, D.T., and Condon, R.H. (2009) Influence of jellyfish blooms on carbon, nitrogen and phosphorus cycling and plankton production. Hydrobiologia. 616:133-149.

Reid, J.W. and Williamson, C.E. (2009) Copepoda. In Ecology and Classification of North American Freshwater Invertebrates 3rd Edition. Academic Press.

Reinikainen, M., Ketola, M., and Walls, M. (1994) Effects of the concentrations of toxic Microcystis aeruginosa and an alternative food on the survival of Daphnia pulex. Limnology and Oceanography. 39(2):424-432.

Richardson, A.J. (2008) In hot water: zooplankton and climate change. ICES Journal of Marine Science. 65:279-295.

Santore, R.C., Di Toro, D.M., Paquin, P.R., Allen, H.E., and Meyer, J.S. (2001) Biotic ligand model of the acute toxicity of metals. 2. Application to acute copper toxicity in freshwater fish and Daphnia. Environmental Toxicology and Chemistry. 20(10):23972402 .

Saros, J.E., Michel, T.J., Interlandi, S.J., and Wolfe, A.P. (2005) Resource requirements of Asterionella formosa and Fragilaria crotonensis in oligotrophic alpine lakes: implications for recent phytoplankton community reorganizations. Canadian Journal of Fisheries and Aquatic Science. 62:1681-1689.

Schalau K., Rinke K., Straile D. (2008) Temperature is the key factor explaining interannual variability of Daphnia development in spring: a modelling study. Oecologia. 157:531-543.

Schindler, D.W. (1968) Feeding, assimilation and respiration rates of Daphnia magna under various environmental conditions and their relation to production estimates. Journal of Animal Ecology. 37(2):369.

Schindler, D.E., Carpenter, S.R., Cole, J.J., Kitchell, J.F., and Pace, M.L. (1997) Influence of Food Web Structure on Carbon Exchange between Lakes and the Atmosphere. Science. 5323(277):248-251.

Schindler, D.W. (2001) The cumulative effects of climate warming and other human stresses on Canadian freshwaters in the new millennium. Canadian Journal of Fisheries and Aquatic Sciences. 58:18-29. 
Seda, J. and Petrusek, A. (2011) Daphnia as a model organism in limnology and aquatic biology: introductory remarks. Journal of Limnology. 70.

Shannon, C.E. (1948) A mathematical theory of communication. Bell System Technical Journal. 27:379-423.

Slobodkin, L.E. and Bossert, P.E. (1991) The Freshwater Cnidaria - or Coelenterates. In Thorp, J.H. and Covich, A.P., (ed.), Ecology and Classification of North American Freshwater Invertebrates. Academic Press, San Diego. Pp. 125-142.

Smith, F. (1963) Population dynamics in Daphnia magna and a new model for population growth. Ecology. 44(4):651-663.

Smith, A. S. and J. E. Alexander, Jr. (2008) Potential effects of the freshwater jellyfish Craspedacusta sowerbii on zooplankton community abundance. Journal of Plankton Research. 30(12):1323-1327.

Solomon, S., Qin, D., Manning, M., Chen, Z., Marquis, M., Averyt, K.B., Tignor, M., and Miller, H.L. (2007) Contribution of Working Group I to the Fourth Assessment Report of the Intergovernmental Panel on Climate Change. Cambridge University Press, Cambridge, UK.

Southworth, G.R., Beauchamp, J.J., and Schmieder, P.K. (1978) bioaccumulation potential of polycyclic aromatic hydrocarbons in Daphnia pulex. Water Research. 12:973-977.

Spadinger, R. and Maier, G. (1999) Prey selection and diel feeding of the freshwater jellyfish, Craspedacusta sowerbii. Freshwater Biology. 41:567-573.

Spencer, C.N., McClelland, B.R. and Stanford, J.A. (1991) Shrimp Stocking, Salmon Collapse and Eagle Displacement. Bioscience. 41:14-21.

Stefani, F., Leoni, B., Marieni, A., and Garibaldi, L. (2010) A new record of Craspedacusta sowerbii, Lankester 1880 (Cnidaria, Limnomedusae) in Northern Italy. Journal of Limnology. 69(1):189-192.

Statham, P.J. (2012) Nutrients in estuaries - An overview and the potential impacts of climate change. Science of the Total Environment. 434:213-227.

Sterner, R.W. and Hessen, D. O. (1994) Algal nutrient limitation and the nutrition of aquatic herbivores. Annual Review of Ecology, Evolution and Systematics. 25:1-29.

Sterner, R.W. and Elser, J.J. (2002) Ecological stoichiometry: the biology of elements from molecules to the biosphere. Princeton University Press, Princeton. 
Strayer, D.L., Eviner, V.T., Jeschke, J.M., and Pace, M.L. (2006) Understanding the long-term effects of species invasions. Trends in Ecology and Evolution. 21(11):645651.

Suggitt, A.J., Gillingham, P.K., Hill, J.K., Huntley, B., Kunun, W.E., Roy, D.B., and Thomas, C.D. (2010) Habitat microclimates drive fine-scale variation in extreme temperatures. Oikos. 120(1).

Suggitt, A.J., Stefanescu, C., Páramo, F., Oliver, T., Anderson, B.J., Hill, J.K., Roy, D.B., Brereton, T., and Thomas, C.D. (2012) Habitat associations of species show consistent but weak response to climate. Biology Letters. 8(4):590-593.

Thompson, P.L., St-Jacques, M.C., and Vinebrooke, R.D. (2008) Impacts of climate warming and nitrogen deposition on alpine plankton in lake and pond habitats: an in vitro experiment. Arctic, Antarctic, and Alpine Research. 40(1):192-198.

Throp, James H. and Covich, Alan P. (1991) Ecology and Classification of North American Freshwater Invertebrates. Academic Press. San Diego, California.

Thuiller, W. (2009) Climate change and the ecologist. Nature. 448:550-552.

Van de Waal, D.B., Verschoor, A.M., Verspagen, J.M.H., van Donk, E., and Huisman, J. (2010) Climate-driven changes in the ecological stoichiometry of aquatic ecosystems. Frontiers in Ecology and the Environment. 8(3):145-152.

Vitousek, P.M., Antonio, C.M., Loope, L.L., Westbrooks, R. (1996) Biological invasions as global environmental change. American Scientist. 84(5):468-479.

Vitousek, P.M., Aber, J.D., Howarth, R.W., Likens, G.E., Matson, P.A., Schindler, D.W., Schelsinger, W.H., and Tilman, D.G. (1997) Human alteration of the global nitrogen cycle: sources and consequences. Ecological Applications. 7:737-750.

Van Doorslaer, W., Vanoverbeke, J., Duvivier, C., Rousseaux, S., Jansen, M., Jansen, B., Feuchtmayr, H., Atkinson, D., Moss, B., Stoks, R., and DeMeester, L., (2009) Local adaptation to higher temperatures reduces immigration success of genotypes from a warmer region in the water flea Daphnia. Global Change Biology. 15:3046-3055.

Wagner, A. and Benndorf, J. (2007) Climate-driven warming during spring destabilizes a Daphnia population: a mechanistic food web approach. Oecologia. 151:351-364.

Walthall, W.K. and Stark, J.D. (1999) The acute and chronic toxicity of two xanthene dyes, fluorescein sodium salt and phloxine B, to Daphnia pulex. Environmental Pollution. 104(2):207-215.

Wang, H., Sterner, R.W., and Elser, J.J. (2012) On the "strict homeostasis" assumption in ecological stoichiometry. Ecological Modelling. 243:81-88. 
Whitehead, P.G. and Crossman, J. (2012) Macronutrient cycles and climate change: Key science areas and an international perspective. Science of the Total Environment. 434:1317.

Wilhelm, S. and Adrian, R. (2008) Impact of summer warming on the thermal characteristics of a polymictic lake and consequences for oxygen, nutrients, and phytoplankton. Freshwater Biology. 53:226-237.

Williams, P.J., Dick, K.B., and Yampolsky, L.Y. (2012) Heat tolerance, temperature acclimation, acute oxidative damage and canalization of haemoglobin expression in Daphnia. Evolutionary Ecology. 26:591-609

Williamson, C.E. and Stoeckel, L.J. (1989) Predation risk and the structure of freshwater zooplankton communities. Oecologia 79:76-82.

Williamson, C.E., Saros, J.E., and Schindler, D.W. (2009) Sentinels of Change. Science. 123:887-888.

Winder, M. and Cloern, J.E. (2010) The annual cycles of phytoplankton biomass. Philosophical Transactions of the Royal Society. 365(1555):3215-3226.

Winner, R.W. (1986) Interactive effects of water hardness and humic acid on the chronic toxicity of cadmium to Daphnia pulex. Aquatic Toxicology. 8(4):281-293.

Winter, L.T., Foster, I.D.L., Charlesworth, S.M., and Less, J.A. (2001) Floodplain lakes as sinks for sediment-associated contaminants-a new source of proxy hydrological data? The Science of the Total Environment. 266:187-194.

Wojtal-Frankiewicz, A. (2012) The effects of global warming on Daphnia spp. population dynamics: a review. Aquatic Ecology. 46:37-53.

Yurista, P.M. (2000) Cyclomorphosis in Daphnia lumholtzi induced by temperature. Freshwater Biology. 43:207-213. 


\section{APPENDIX}

OXFORD UNIVERSITY PRESS LICENSE

TERMS AND CONDITIONS

TERMS AND CONDITIONS
Nov 27, 2012
This is a Licensc Agreement between Allison S Simith ( You") and Oxford University Press
("Oxford Unversity Press") provided by Copy right Clearance Center ("CCC"), The license
consists of your order details, the terms and conditions provided by Oxford University Press.
and the payment terms and conditions.

All payments must be made in full to cCC. For payment instructions, please see

\begin{tabular}{|c|c|}
\hline License Number & 3037100 \\
\hline License date & Now 27 \\
\hline Licenged content pwiblistier & Oxford \\
\hline Lisensed content publication & Jounn \\
\hline Licensed content ritie & $\begin{array}{l}\text { Potentia } \\
\text { on zoopl }\end{array}$ \\
\hline Licersed content author & Aflisan \\
\hline Ucensed content date & $12 / 01 / 20$ \\
\hline Type of Use & Thesis/ \\
\hline \multicolumn{2}{|l|}{ institution name } \\
\hline The of your work & $\begin{array}{l}\text { Zeopian- } \\
\text { Warming }\end{array}$ \\
\hline Puslisher of your work & $n / a$ \\
\hline Expected publication date & Dec 201 \\
\hline Porthissons cost & 0.00 US \\
\hline value added tax & 0,00 US \\
\hline foral & 0.00 US: \\
\hline Total & $0.00 \cup 5$ \\
\hline
\end{tabular}

Terms and Conditions

SIANDARD TERMS AND CONDITIONS FOR REPRODICTION OF MATERIAL FROM AN OXFORD UNIVERSITY PRESS JOURNAL

1. Use of the material is restricted to the is pe of use specified in your order details.

2. This permission covers the use of the material in the linglish language in the following territory: world. If you have requested additional permission to translate this material, the terms and conditions of this reuse will be set out in clause 12

3. This permission is limited to the particular use atuthorized in (1) above and docs not allow you to sanction its use elsewhere in any other format other than specilied above, nor does il apply to quotations. images, artistic works etc that have been reproduced from sther source 
which may be part of the material to ba used.

4. No alteration, omission of addition is made to the material without wur written consent. Permission must be re-cleared with Oxford Unversity Press if when you decide to reprint

5. The following eredit line appears wherever the matcrial is used suthor, tille, journal, year. volume, issue number, pagination, by permission of Oxford University Press or the sponsoring socicty if the journal is a socicty journal. Where a journal is being published on behalf of a learned society, the details of that society must he included in the oredit line.

6. For the reproduction of a fill arlicle from an Oxford Iniversily Press journal for whatever purpose, the corresponding author of the matcrial concerned should be informed of the proposed use. Contact details for the corresponding authors of all Oxford Lniversity Press woumal contact can be found alongside cither the abstrust or full text of the article conecrnod. ncessible from www.nxfordjumals org Should there be a problem clearing the re rights. please contact journals. permissions a oxfordjournals ors

7. If the credit line or acknowledgement in our publication indicates that any of the ligures. images or photos was reproduced, drawn or modified from an carlicr source it will be necessary for you to clear this permission with the original publisher as well. If this permission has not been obtained. plcase note that this matcrial cannot be included in your publication photocopies.

8. While you may exercise the rights licensed immediatcly upon issuance of the license at the end of the licensing process for the transaction, provided that you have disclosed complete and accurate details of your pronetsed use, no license is finaliy eftective unless and until full payment is received from you (either by Oxford Unwersity Press or by Copyright Clearance ("enter (CCC)) as provided in CCC's Billing and Payment terms and conditions. It full payment is not received on a timely basis, then any license preliminarily granted shall be deened aulomatieally revoked and shall be void as if never granted. Further, in the event that you bresch any of these terms and conditions or any of CCC's Billing and layment ferms and conditions, the license is automatically revoked and shall be void as if never granted. Usc of naterials as dexcribed in a revoked license, as well as any use of the materials beyond the scope of an unrevoked license, may constitule copyright infringement and Oxford University Press reserves the right to take amy and all action to protect its copyright in the materials.

9. This liccnse is personal to you and may not be sublicensed. assigned or transferred by you 10 sny other person without Ox ford Universicy l'pess's writlen permission.

10. Oxford University l'ress reserves all rights not specifically grunied in the combination of (1) the license details provided by you and accepted in the course of this licensing transaction, (ii) these terms and condilions and (iii) CCC"s Billing and Payment terms and conditions.

11. You hereby indemnify and agree whold hamless Oxford Univerity Press and CCC and their respective officers, directors, employs and agents. from and aguinst any and al. clains arising out of your use of the liecnsed material other than as specifically authorized pursuant to this license. 
Rightslink Printable Liecnse

Page 3 of 3

12. Other Terms and Conditions:

1. 4

If you would like to pay for this license now, please remit this license along with your payment made payable to "COPYRIGHT CLEARANCE CENTER" otherwise you will be

invoiced within 48 hours of the license date. Payment should be in the form of a check or money order referencing your account number and this invoice number RLNK500905431.

Once you receive your invoice for this order, you may pay your invoice by credit card.

Please follow instructions provided at that time.

Make Payment To:

Copyright Clearance Cente

Dept 001

P.O. Box 843006

Boston, MA 02284-3006

For suggestions or comments regarding this order, contact RightsLink Customer

Support: customercaregcopyright.com or +1-877-622-5543 (toll free in the US) or +1-

978-646-2777.

Gratis licenses (referencing $\$ 0$ in the Total field) are free. Please retain this printable license for your reference. No payment is required.

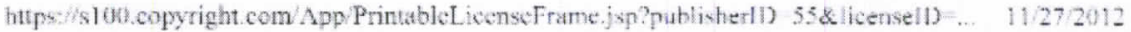




\section{CURRICULUM VITAE}

\section{Allison S. Smith}

University of Louisville

Department of Biology

139 Life Sciences

Louisville, KY 40292

$502-419-5832$

allisunsmith@gmail.com

\section{Research Interests}

Climate Change Ecology, Invasion Ecology, Aquatic Ecosystem Ecology, Statistics of Island Biogeography

\section{Current Research}

Effects of climate change on freshwater ecosystems

Temperature and food effects on zooplankton. How do the interactive effects of temperature and biogeochemistry impact Daphnia growth and reproduction?

Effects of Craspedacusta sowerbii on zooplankton dynamics. How are zooplankton species differentially affected by medusa presence? How does community composition respond to medusae in a natural lake? What factors correlate with medusa presence?

Resting egg production in Daphnia

\section{$\underline{\text { Research Experience }}$}

Green River Project to preserve the endangered fanshell mussel (Cyprogenia spp.), Kentucky Department of Fish and Wildlife

Summer 2008

Great Rivers Environmental Monitoring and Assessment Program (GR-EMAP): zooplankton identification and counting May 2005 to July 2007

Wilson Creek Restoration Project: zooplankton sampling and identification, chl a collection and processing, collection of stream and hydrolab data May 2005 to December 2005 
Competition experiment between exotic $D$. lumholtzi vs. native $D$. magna and $D$. pulicaria measuring population growth and resting egg production with Dr. K. Acharya and Dr. Jeff Jack

Summer and Fall 2005

Life History Study of Bosmina longiristris with Dr. Kumud Acharya Summer 2004

Mesocosm study of algal blooms in Ohio River with Roger Tucker, M.S. Summer 2004

Study of Amblyopsis spalaea (blind cave fish) with Dr. Rob McCandless Summer 2003

\section{$\underline{\text { Publications }}$}

John Vick, Carol Norton, Lauren Heberle and Allison Smith (2012) State of Metropolitan Housing Report 2012. Center for Environmental Policy and Management. Prepared for the Metropolitan Housing Coalition, Louisville, Kentucky.

Allison S. Smith and Daniel Weinstein. (2012) Growing a Farmers' Market in Your Neighborhood: Recommendations for Success. Center for Environmental Policy and Management, University of Louisville. http://louisville.edu/cepm/publications/practice-guides1/Growing $\% 20 \mathrm{a} \% 20$ Farmers $\% 20$ Market $\% 20$ in $\% 20$ Your $\% 20$ Neighborhood.pdf

John Vick, Carol Norton, and Allison Smith (2011) State of Metropolitan Housing Report 2011. Center for Environmental Policy and Management. Prepared for the Metropolitan Housing Coalition, Louisville, Kentucky.

Allison Smith, Kumud Acharya, and Jeff Jack. (2009) Overcrowding, Food and P Limitation Effects on Resting Egg Production in Daphnia lumholtzi.

Hydrobiologia, 618(1): 47-56.

Allison S. Smith and James Alexander. (2008) Potential effects of Craspedacusta sowerbii on zooplankton community dynamics. Journal of Plankton Research, 30(12): 1323-1327.

Kumud Acharya, Jeff Jack, and Allison Smith. (2006) Stoichiometry of Daphnia lumholtzi and their invasion success: Are they linked? Archiv Fur Hydrobiologie 165 (4): 433-453(21). 


\section{Grants}

Doctoral Dissertation Completion Grant, Spring 2011

Travel Grant, Biology Graduate Student Association, Spring 2011, \$250

Travel Grant, Advancing the Science of Limnology and Oceanography

Aquatic Sciences Summer Meeting, June 2010, $\$ 500$

Kentucky Society of Natural History Woody Boebinger Memorial Scholarship Graduate Student Grant for Research in the Fields of Natural History/Biodiversity of Kentucky, Summer 2009, $\$ 750$

Student Government Association Travel Grant, 2010, $\$ 300$

Student Government Association Travel Grant, 2009, $\$ 300$

International Travel Grant, U of L Center for International Affairs, 2009, $\$ 300$

\section{$\underline{\text { Scholarships and Awards }}$}

First Place, Graduate Research Competition, Kentucky Academy of Sciences 2007 Annual Meeting, Ecology/Environmental Science session. "Potential effects of Craspedacusta sowerbii medusae on the freshwater zooplankton of a small lake"

Clay Memorial Biology Scholarship, Biology Department Awards Day University of Louisville, April 22, 2008, $\$ 1000$

Biology Graduate Student Association Publication Award, Biology Department Awards Day, University of Louisville, April 22, 2008

Biology Graduate Student Association Presentation Award, Biology Department Awards Day, University of Louisville, April 24, 2007

"Craspedacusta sowerbii in a small lake in Kentucky"

2006 Stuart E. Neff Award for "the undergraduate Biology student who has shown outstanding ability in the area of environmental biology"

Fellow in Summer Research Opportunity Program, University of Louisville Graduate School, Summer 2003 


\section{$\underline{\text { Positions Held }}$}

Graduate Assistant

Advanced Placement Summer Institute

University of Louisville

June 18-22, 2012

Research Assistant

Center for Environmental Policy and Management

Environmental Finance Center: Serving EPA Region 4

University of Louisville

Department of Sociology

September 2011 to present

Graduate Assistant

Advanced Placement Summer Institute

University of Louisville

June 20-24, 2011

Doctoral Fellow

Doctoral Dissertation Completion Grant

Spring 2011

Graduate Teaching Assistant

BIO 244 Principles of Biology Lab

Spring 2008 to Fall 2010

BIO 104 Introduction to Biology Lab

August 2006 through Fall 2007

Research Assistant

Center for Environmental Science, University of Louisville

May 2005 to August 2006

Great Rivers Environmental Monitoring and Assessment Program (GR-EMAP)

\section{Accomplishments}

Interviewed on National Public Radio station WFPL by Kristin Espeland Gourlay, "Climate Change Comes to the Ohio River"

September 10, 2009 http://www.wfpl.org/2009/09/10/climate-change-comes-to-the-ohio-river/

Member and Contributor, Local Impacts Subcommittee of the Climate Change Committee in conjunction with the Partnership for a Green City, Louisville Metro Government, Louisville, Kentucky, 2008 
Reviewer

Agricultural Science Research Journal, 2012

Aquatic Invasions, 2011

African Journal of Food Science, 2011

Hydrobiologia, 2009

Journal of Tropical Biology and Conservation, 2009

Graduate Teaching Academy, University of Louisville

Fall 2008 - Spring 2009

President, Biology Graduate Student Association, 2008

Dean's List, University of Louisville, Fall 2003

Dean's List, Jefferson Community College, Spring 2000

\section{Presentations}

Doctoral Dissertation Defense, November 19, 2012

"Zooplankton in Freshwaters: Potential Responses to Global Warming, Nutrient Enrichment, and Exotic Jellyfish"

Oral Presentation, Biology Department Awards Day, 2012

"Is it hot in here? Temperature and food effects on Daphnia growth and reproduction"

Oral Presentation, ASLO (American Society of Limnology and Oceanography), 2010

"They grow up so fast: Temperature effects on zooplankton growth rate"

Oral Presentation, Covering the Ohio River Valley: A Convergence of Media and Scientists, February 2010. "Changes on our shores: How will climate change and invasive species impact riverine ecosystems?"

Poster Presentation, ASLO, Nice, France, January 2009

"Freshwater Jellyfish C. sowerbii Effects on Zooplankton Abundance"

Invited guest lecture, September 2008

St. Catherine College, Bardstown, Kentucky, "Climate change effects on aquatic invasive species"

Oral presentation, ASLO summer meeting, St. John's, Newfoundland, June 2008, "Potential effects of Craspedacusta sowerbii medusae on the freshwater zooplankton of a small lake" 
Oral Presentation, Biology Department Awards Day, April 22, 2008

"The statistics behind Island Biogeography"

Oral presentation, Kentucky Academy of Sciences 2007 Annual Meeting, "Potential effects of Craspedacusta sowerbii medusae on the freshwater zooplankton of a small lake"

Oral Presentation, ASLO, Aquatic Sciences Meeting, Santa Fe, New Mexico, February 2007, "Effects of overcrowding, food limitation, and light level on Daphnia lumholtzi resting egg production"

Oral Presentation, ORBCRE (Ohio River Basin Consortium for Research and Education), Murray State University, October 26, 2006

"Effects of overcrowding, food limitation, and light level on Daphnia lumholtzi resting egg production"

Poster Presentation, ASLO Summer Meeting, Victoria, British Columbia, June 2006, "Stoichiometry of Daphnia lumholtzi and their invasion success: Are they linked?"

Oral Presentation, CEEB Spring Research Symposium, May 2006

"Overcrowding, Light, Food and P Limitation Effects on Daphnia lumholtzi"

Poster Presentation, Undergraduate Research Symposium

University of Louisville, April 2006

"Overcrowding, Light, Food and P Limitation Effects on Daphnia lumholtzi"

\section{$\underline{\text { Education }}$}

University of Louisville

Louisville, KY 40292

Ph.D. in Biology

December 2012

University of Louisville

Louisville, KY 40292

B.S. in Biology with concentration in Conservation Ecology

May 2006 


\section{Memberships}

Ecological Society of America

American Society of Limnology and Oceanography

Union of Concerned Scientists

National Center for Science Education

Kentucky Academy of Sciences

Biology Graduate Student Association, U of L

\section{Community Service}

Volunteer Educator, Louisville Nature Center

April 2009 to present

Delta Society Pet Partners, Therapy Dog Program

January 2010 to March 2012

Volunteer, Every 1 Reads, Meyzeek Middle School, Louisville, KY 2009-2010, 2010-2011

Judge, Manual High School Regional Science Fair, March 2009

Judge and Mentor, Manual High School Science Fair, 2006-2007

Judge, Christian Academy of Louisville Science Fair, January 2007

Judge, Meyzeek Middle School $8^{\text {th }}$ Grade Science Fair, 2005

Advisor, Meyzeek Middle School Advising Program

Volunteer, Olmstead Parks Conservancy

Student Volunteer, ASLO 